Food and Agriculture
Organization of the
United Nations

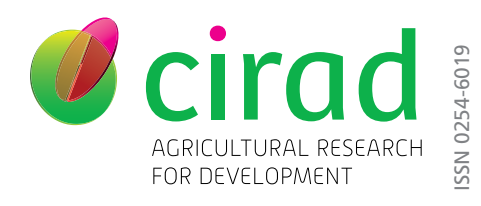

\title{
The economics of pastoralism in Argentina, Chad and Mongolia
}

Market participation and multiple livelihood strategies in a shock-prone environment

FAO ANIMAL PRODUCTION AND HEALTH / PAPER 182

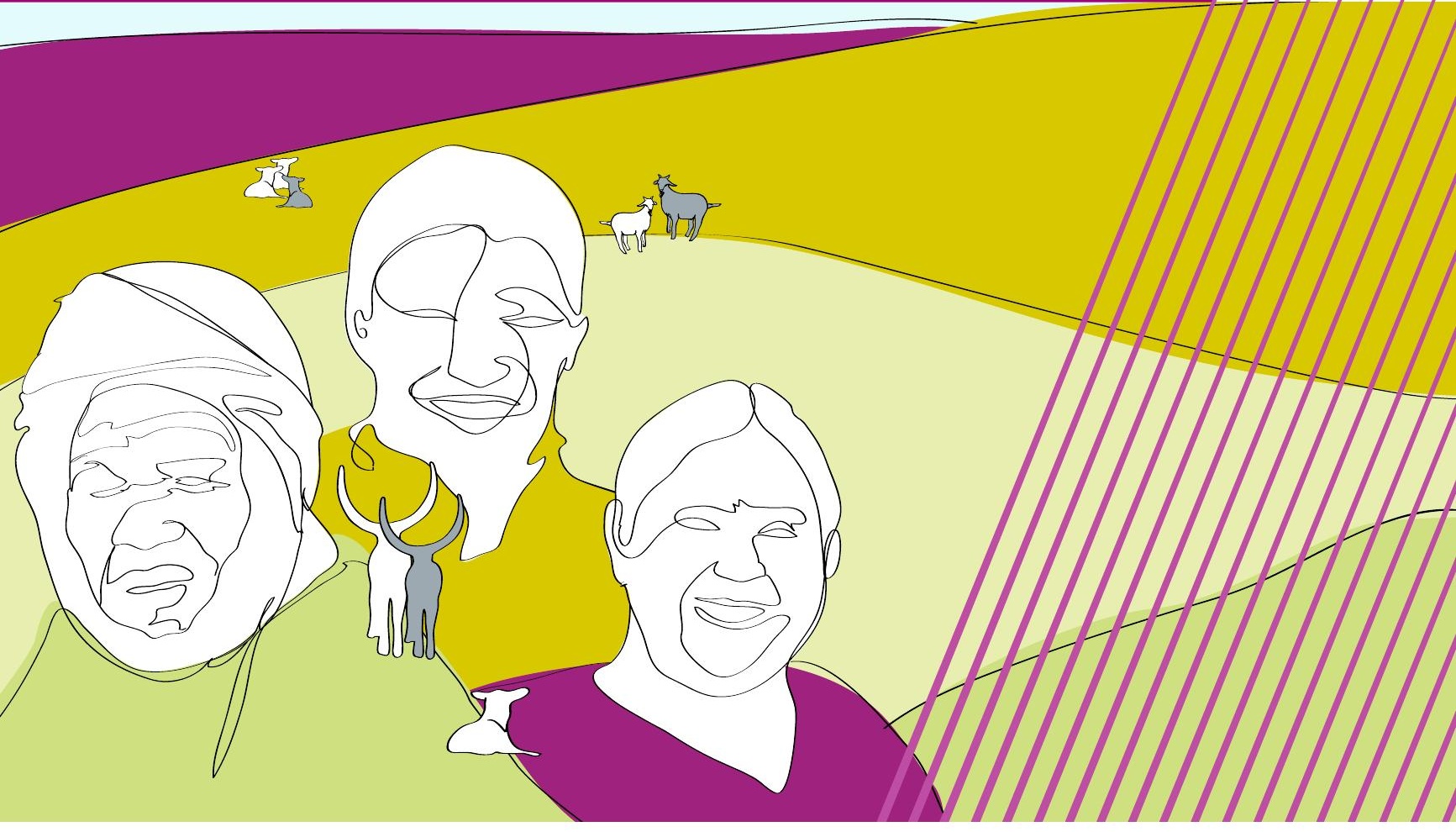





\section{The economics of pastoralism in Argentina, Chad and Mongolia} Market participation and multiple livelihood strategies in a shock-prone environment

Published by

the Food and Agriculture Organization of the United Nations and

Centre de Coopération Internationale en Recherche Agronomique pour le Développement 
The designations employed and the presentation of material in this information product do not imply the expression of any opinion whatsoever on the part of the Food and Agriculture Organization of the United Nations (FAO) or Centre de Coopération Internationale en Recherche Agronomique pour le Développement (CIRAD) concerning the legal or development status of any country, territory, city or area or of its authorities, or concerning the delimitation of its frontiers or boundaries. The mention of specific companies or products of manufacturers, whether or not these have been patented, does not imply that these have been endorsed or recommended by FAO or CIRAD in preference to others of a similar nature that are not mentioned.

The views expressed in this information product are those of the author(s) and do not necessarily reflect the views or policies of FAO or CIRAD.

ISSN 0254-6019 (print)

ISBN 978-92-5-133377-8 (FAO)

ISBN 978-2-87614-760-7 (CIRAD)

(C) FAO and CIRAD, 2020

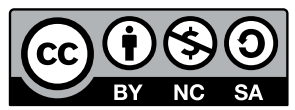

Some rights reserved. This work is made available under the Creative Commons Attribution-NonCommercialShareAlike 3.0 IGO licence (CC BY-NC-SA 3.0 IGO;

https://creativecommons.org/licenses/by-nc-sa/3.0/igo/legalcode).

Under the terms of this licence, this work may be copied, redistributed and adapted for non-commercial purposes, provided that the work is appropriately cited. In any use of this work, there should be no suggestion that FAO endorses any specific organization, products or services. The use of the FAO logo is not permitted. If the work is adapted, then it must be licensed under the same or equivalent Creative Commons licence. If a translation of this work is created, it must include the following disclaimer along with the required citation: "This translation was not created by the Food and Agriculture Organization of the United Nations (FAO). FAO is not responsible for the content or accuracy of this translation. The original English edition shall be the authoritative edition."

Disputes arising under the licence that cannot be settled amicably will be resolved by mediation and arbitration as described in Article 8 of the licence except as otherwise provided herein. The applicable mediation rules will be the mediation rules of the World Intellectual Property Organization http://www.wipo.int/amc/en/mediation/rules and any arbitration will be conducted in accordance with the Arbitration Rules of the United Nations Commission on International Trade Law (UNCITRAL).

Third-party materials. Users wishing to reuse material from this work that is attributed to a third party, such as tables, figures or images, are responsible for determining whether permission is needed for that reuse and for obtaining permission from the copyright holder. The risk of claims resulting from infringement of any third-party-owned component in the work rests solely with the user.

Sales, rights and licensing. FAO information products are available on the FAO website (www.fao.org/publications) and can be purchased through publications-sales@fao.org. Requests for commercial use should be submitted via: www.fao.org/contact-us/licence-request. Queries regarding rights and licensing should be submitted to: copyright@fao.org 


\section{Contents}

Acknowledgements

List of Acronyms

Executive summary

Key messages

vii

ix

$\mathrm{xi}$

$\mathrm{xV}$

Introduction 1

Strong recognition of the knowledge gaps 2

The use of appropriate concepts, approaches, and methods 3

$\begin{array}{ll}\text { Argentina } & 13\end{array}$

$\begin{array}{ll}\text { Background and macro context } & 13\end{array}$

Data collection and management: inclusiveness

of pastoral organizations

Pastoralism: rearing diverse animal species $\quad 17$

$\begin{array}{ll}\text { Pastoralism and revenue generation } & 18\end{array}$

Pastoralism and direct production costs $\quad 22$

$\begin{array}{ll}\text { Pastoralism and wealth creation } & 22\end{array}$

$\begin{array}{ll}\text { Pastoralism and revenue distribution } & 23\end{array}$

$\begin{array}{ll}\text { Pastoralism and multifaceted perceived shocks } & 25\end{array}$

Pastoralism and contingency strategies $\quad 32$

$\begin{array}{ll}\text { Chad } & 35\end{array}$

Background and macro context $\quad 35$

Data collection and management: inclusiveness of pastoral organizations 36

$\begin{array}{ll}\text { Pastoralism and revenue generation } & 39\end{array}$

Pastoralism and direct production costs 41

$\begin{array}{ll}\text { Pastoralism and wealth creation } & 43\end{array}$

Pastoralism and revenue distribution $\quad 43$

Pastoralism and multifaceted shocks 43

Pastoralism and contingency strategies 46

$\begin{array}{ll}\text { Mongolia } & 47\end{array}$

$\begin{array}{ll}\text { Background and macro context } & 47\end{array}$

Data collection and management:

inclusiveness of pastoral organizations $\quad 49$

Pastoralism: rearing of various animal species $\quad 50$

Pastoralism and revenue generation $\quad 52$

Pastoralism and direct production costs $\quad 54$

$\begin{array}{ll}\text { Pastoralism and wealth creation } & 57\end{array}$

Pastoralism and revenue distribution $\quad 58$

$\begin{array}{ll}\text { References } & 59\end{array}$ 


\section{FIGURES}

Figure 1: Conceptual framework for household revenue analysis

Figure 2: Conceptual framework for pastoral household food and non-food expenditure analysis

Figure 3: Conceptual framework for direct production and non-production cost analysis

Figure 4: GDP evolution

5: Rural population change (\% of total population)

Figure 6: LSU distribution by region 17

Figure 7: Distribution of average gross revenue by province/region (Argentine Peso) 18

Figure 8: Breakdown of average gross revenue by province/region 19

Figure 9: Breakdown of average livestock revenue by province/region 20

Figure 10: Breakdown of other sources of monetary revenue by province/region 20

Figure 11: Breakdown of the average gross revenue by category of household 21

Figure 12: Direct production costs (Argentine Peso) 22

Figure 13: Breakdown of the direct production costs by regions 23

Figure 14: Direct economic contribution 24

Figure 15: Evolution of the Gini index in Argentina 24

Figure 16: Lorenz curve and Gini index by revenue source 25

Figure 17: Occurrence of shocks by type 26

Figure 18: Perceived shocks in the survey area $\quad 27$

Figure 19A: Multiscale perceived covariate and idiosyncratic shocks in Chaco 28

Figure 19B: Multiscale perceived covariate and idiosyncratic shocks in Cuyo 29

Figure 19C: Multiscale perceived covariate and idiosyncratic shocks in Noroeste $\quad 30$

Figure 19D: Multiscale perceived covariate and idiosyncratic shocks in Patagonia 31

Figure 20: Strategies reported by investigated households 33

Figure 21: GDP evolution $\quad 35$

Figure 22: Population, total 36

Figure 23: Distribution of TLUs by province 38

Figure 24: Average overall revenue distribution by provinces (Central African CFA franc) 39

Figure 25: Disaggregation of the average overall revenue by province 40

Figure 26: Breakdown of average revenue by household income category 41

Figure 27: Distribution of average expenditures by province (Central African CFA franc) 42

Figure 28: Breakdown of average expenditures by household category 42

Figure 29: Direct economic contribution to GDP and Ag. GDP 44

Figure 30: Distribution of monetary and gross revenue 44

Figure 31: Perceived shocks in the study area $\quad 45$

Figure 32: Strategies prioritized by HHs in the study area 46

Figure 33: GDP evolution $\quad 47$

Figure 34: Population, total 48

Figure 35: Animal population in Mongolia 49

Figure 36: Species composition of an average herd 51

Figure 37: Livestock distribution according to different approaches 53

Figure 38: Some average revenue indicators (Mongolian Tugrik) 53

Figure 39: Components of the annual total revenue by regions 55

Figure 40: Components of the annual total revenue by category of household 56

Figure 41: Direct production costs by regions (Mongolian Tugrik) 56

Figure 42: Direct production costs by agroecological regions 57

Figure 43: Direct economic contribution to GDP 57

Figure 44: Revenue distribution in Mongolian pastoral and agropastoral areas $\quad 58$ 


\section{MAPS}

Map 1: Spatial distribution of sample investigated households in Argentina

Map 2: Distribution of sample investigated household at the provincial level in Chad

Map 3: Distribution of sample investigated household at the provincial level in Mongolia

\section{TABLES}

Table 1: Sampling size determination $\quad 10$

Table 2: Household characterization in the three target countries 11

Table 3: Animal species' equivalent of the average LSU of 65

Table 4: Categories of pastoral households according to their average gross revenue 21

Table 5: Animal species' equivalent of the average TLU of $192 \quad 38$

Table 6: Classification of households according to their overall average income $\quad 40$ 



\section{Acknowledgements}

The study was prepared for the Pastoral Knowledge Hub (PKH), an initiative bringing together pastoralists and the main actors working with them to join forces and create the synergies for dialogue and pastoralist development. Activities were funded by the International Fund for Agricultural Development (IFAD). Overall guidance and supervision were provided by Serena Ferrari, Gregorio Velasco Gil and Badi Besbes from the FAO Animal Production and Health Division.

The research team that wrote the report was led by Abdrahmane Wane (Centre de coopération internationale en recherche agronomique pour le développement CIRAD and International Livestock Research Institute ILRI) and included the following CIRAD colleagues: Jean Daniel Cesaro, Guillaume Duteurtre, Ibra Touré, Alioune Ndiaye, Véronique Alary, Xavier Juanès and Alexandre Ickowicz. The report benefited also from external review and contributions from Serena Ferrari and Gregorio Velasco Gil (Food and Agriculture Organization of the United Nations FAO).

Many other partners contributed to this study through primary data collection and by providing their expertise to better understand context-driven characteristics, challenges and prospects of the economics of pastoralism:

- In Argentina: we acknowledge the contribution of the Fundación Gran Chaco and Redes Chaco, in particular Pablo Frere, Héva Anne Brunelle, Sebastián Abeledo, Fabiana Menna and Agustín Noriega. Special and emotional thought to Leonardo Javier Navarro who recently passed away. In addition, we would like to thank Foro Nacional de Agricultura Familiar, Instituto Nacional de Tecnología Agropecuaria, Secretaría de Agricultura Familiar, and the following grassroots organizations: Coordinadora de Tierras de la Ruta 81, COMAR-Cooperativa Mujeres Artesanas del Gran Chaco, Comunidad Campesina de Los Blancos, Pastoras del Monte, Cooperativa La Amistad, Cultura Rural Patagónica, La cooperativa ganadera indígena, Productores de la Asociación Quebracho de Pequeños Productores Agropecuarios. Many thanks also to Servicio Nacional de Sanidad y Calidad Agroalimentaria, Programa Ganadero del Ente, Municipio de Paso de Indios, Secretaria de Coordinación del Interior, Centro de Validación de Tecnologías Agropecuarias, Programa Mohair, El Ceibal Asociación Civil, El futuro está en el monte, Fundación Cruzada Patagónica, PastorAmericas and other local stakeholders.

- In Chad: the study benefited from a contribution from the Réseau Billital Maroobé (RBM) and the Confédération des Organisations Professionnelles des Pasteurs et Acteurs de la Filière Bétail au Tchad (COPAFIB), in particular Blamah Jallo, Ahmat Adoum Aboulfathi and Chec Ibrahima Ouattara, who facilitated the field survey. Many thanks also to the Chadian authorities for being receptive and supportive, colleagues and leaders from the pastoralist organizations of Chad, technical and financial partners for their support, mainly the Swiss Cooperation Office and the Plateforme Pastorale du Tchad. 
- In Mongolia: people from the National Federation of Pasture User Groups (NFPUG), in particular Nyam-Ochir Gankhuyag, Dashbal Burmaa, and Sain-Nemekh Sumjidmaa. We also would like to acknowledge the following institutions: the Ministry of Food, Agriculture and Light Industry, the National Statistical Office of Mongolia, the Administration of Land Affairs, Geodesy and Cartography, the students from Mongolian University of Life Science who supported the project implementation, the government offices of aimag and soum, and the rangeland specialists and land managers of each soum.

The authors also wish to acknowledge the FAO country offices of Argentina, Chad, and Mongolia for their continued support and guidance. 


\title{
List of Acronyms
}

\author{
ARS Argentinian Peso \\ CIRAD Centre de Coopération Internationale en Recherche Agronomique pour le \\ Développement \\ COPAFIB Confédération des Organisations Professionnelles des Pasteurs et Acteurs de \\ la Filière Bétail au Tchad \\ FAO Food and Agriculture Organization of the United Nations \\ GDP Gross domestic product \\ GVA Gross value added \\ HH Household \\ IFAD International Fund for Agricultural Development \\ LSU Livestock Standard Unit \\ MNT Mongolian Tughrik \\ NFPUG National Federation of Pasture User Groups \\ PKH Pastoralist Knowledge Hub \\ RBM Réseau Billital Maroobé \\ SFU Sheep Forage Unit \\ TLU Tropical Livestock Unit \\ USD United States dollar \\ XAF Central African CFA Franc
}





\section{Executive summary}

\section{BACKGROUND AND CONTEXT}

Pastoralists are a collective of several hundred million livestock keepers distributed all over the world whose unique livelihoods face challenges that are often linked to the environment in which they live and to the mobility that characterizes them. Pastoralists are the main producers in the world's drylands, mountains and cold areas. Governments often neglect to invest and provide public services and tenure security in rangelands, and private actors are not really keen to be strongly involved. This results from a lack of knowledge and awareness about integrated landscape management within national and local governments, the private sector, and civil society actors. Knowledge about the real contribution of pastoralists to territorial, regional and national economies has yet to percolate down to more national and local actors. One reason is that many integrated landscape management programs lack strong monitoring and evaluation components, especially ones that could be used beyond the household or community scale, making the social, economic and environmental assessment of benefits difficult.

To fill this gap, CIRAD was commissioned by FAO to support pastoral organizations in Argentina, Chad and Mongolia in collecting and analyzing primary data, provide new insights into the economics of pastoralism, and assess the contribution of pastoralism to national GDPs. To add a more dynamic analysis, CIRAD proposed to identify what stakeholders perceive to be the main shocks impacting pastoral systems in Argentina and Mongolia and the main adaptation and coping strategies implemented by pastoralists to cope with these disturbances.

\section{HOW WAS THE STUDY CARRIED OUT?}

The study is based on the elaboration of conceptual frameworks for the determination of income and production costs, the analysis of shocks and strategies, and the analysis of economic contributions. These different frameworks were designed to be appropriate and adapted to the intrinsic characteristics of pastoralism in Argentina, Chad and Mongolia. A preliminary step consisted of identifying pastoralists through a census conducted under the impetus of FAO. For this study, part of this census work was used, and triangulations with information provided by pastoral organizations and national censuses were made to determine the sample of households to be surveyed. Two sampling targets were set based on the capacity of the pastoral organizations to carry out the surveys within the existing time and cost constraints. The main technical constraint was to remain within a margin of error of less than $5 \%$ in accordance with standard statistical approaches. Finally, we analyzed data collected on 1197 pastoral households in Argentina, 803 in Chad, and 765 in Mongolia.

Detailed questionnaires were developed and administered to the households in the samples. Data collection was carried out using tablets and sometimes in paper format due to poor internet connections. Data were then routed to the Open Foris server based 
at FAO in Rome. This made it possible to monitor the information collection process on a day-to-day basis and to make certain adjustments. CIRAD was in charge of extracting the information required for the analysis, and of ensuring the accuracy and integrity of this information. Finally, income and cost analyses were elaborated, economic contributions were identified using value-added and production approaches, and shocks as well as adaptation and coping strategies were examined from the perspective of the actors involved.

\section{MAIN FINDINGS}

Rapid investigations among pastoral households allowed an idea of the average composition of a household's herd. In Argentina, a pastoral household has 65 Livestock Standard Units $(\mathrm{LSU})^{1}$, the equivalent of 30 cattle, 14 camelids, 35 sheep, 137 goats, 11 donkeys, 12 horses, and 13 pigs. In Chad, a pastoral household has on average 192 Tropical Livestock Units (TLU), meaning 102 cattle, 36 camels, 73 sheep, 45 goats, 9 donkeys, and 7 horses. In Mongolia, the average animal ownership for a pastoral household is 78 LSU or 757 equivalent sheep, meaning 29 cattle (including yaks), 2 camels, 193 sheep, 173 goats, 19 horses, and 13 mares.

The average annual gross revenue in pastoral and agropastoral areas is estimated in Argentina at Argentinian Peso (ARS) 577927 (equivalent to United States dollars (USD) 20 5742); in Chad at Central African CFA Franc (XAF) 3030760 (equivalent to USD 5 454); and in Mongolia at Mongolian Tughrik (MNT) 11.8 million (equivalent to USD 4 773). Overall, the average gross revenue is provided by livestock product sales (37\% in Argentina, $54 \%$ in Chad and $74 \%$ in Mongolia), other monetary revenue including off-farm revenue (28\% in Argentina, $16 \%$ in Chad and $16 \%$ in Mongolia) and household self-consumption (35\% in Argentina, 30\% in Chad and 10\% in Mongolia). The breakdown of the gross revenue allows one to see strong regional disparities of the sources of revenue in the three countries. The diversified sources of revenue and the importance of self-consumption in household economies also indicate that pastoral systems fulfill a range of functions, serving as a source of income, food security and flexible labor. In addition, as poverty analyses mainly take an absolute poverty approach, which considers the essential nutritional needs of individuals, incorporating self-consumption becomes relevant to improve current figures about poverty in pastoral regions, particularly in Chad. This also reflects the difficulties in carrying out analyses of household poverty in pastoral systems.

Annual average production costs amount to ARS 52682 (USD 1 875) in Argentina; XAF 815153 (USD 1 467) in Chad and MNT 698653 (USD 283) in Mongolia. In Argentina, production costs are dominated by feed purchases (65\%) and service charges (18\%), whereas in Chad, animal health expenditures and herd restocking constitute the main cost items ( $27 \%$ and $26 \%$ respectively). In Mongolia, costs come from the purchase of services (44\%) and herd restocking (37\%).

1 The "livestock unit", abbreviated as LSU (or sometimes as LU), is a reference unit which facilitates the aggregation of livestock from various species and age as per convention, via the use of specific coefficients established initially on the basis of the nutritional or feed requirement of each type of animal.

The reference unit used for the calculation of livestock units (=1 LSU) is the grazing equivalent of one adult dairy cow producing $3,000 \mathrm{~kg}$ of milk annually, without additional concentrated foodstuffs. (https://ec.europa.eu/eurostat/statistics-explained/index.php/Glossary:Livestock_unit_(LSU))

2 In 2018: 1 USD = 28.09 ARS; 1 USD $=2472.48$ MNT; 1 USD = 555.72 XAF

(https://data.worldbank.org/indicator/PA.NUS.FCRF?locations=RU) 
Pastoral households in all three countries studied are effectively participating in the creation of national wealth. Even when only their monetary/market outputs are considered, pastoralists contribute $0.6 \%$ of the gross domestic product (GDP) in Argentina, $11 \%$ of the GDP in Chad and $9.6 \%$ of the GDP in Mongolia. By incorporating self-consumption as an important component of gross revenue, the contribution of the same households jumps to $1.4 \%$ of the GDP in Argentina, $27 \%$ of the GDP in Chad and $11.9 \%$ of the GDP in Mongolia. Given the importance of self-consumption, particularly in Argentina and Chad, the contribution of pastoralists to national economies appears to be underestimated. This leads to two problems:

- The first is linked to the temporality of income and production costs, which negatively impacts the measurement method of the economic contribution of pastoral households. Indeed, while revenues are calculated on an annual basis, production costs are calculated on a multiannual basis. A quick simulation shows that the contribution of pastoral households declines more or less sharply depending on the average period of time animals are held before being sold. This is because direct production costs related to health, watering, feeding, etc. must continue to be covered during this period.

- The second is linked to a lack of, or the insufficient incorporation of, the multifunctionality of pastoral production systems. The provisioning of other services from pastoral systems are themselves insufficiently measured (biomass production, biodiversity, water cycling, social impacts, etc.). The effective measure and integration of ecosystem services into national accounts remains a challenge. To fully address the multifunctionality of pastoralism, we need to assess the condition of ecosystems in relation to human well-being.

Another major challenge in pastoral systems in all three countries is the high level of economic inequality measured through the tabulation of the Gini index. In Argentina, despite the implementation of successful policies to reduce economic inequality (improvement of working conditions, both rate of employment and the quality of jobs; incorporation of people without formal labor income into the social security system), the Gini index measured in the pastoralist community remains very high. On the basis of gross revenue, the distribution of revenue in Argentinian pastoral areas is very unequal (Gini index: 56.6\%). In Mongolia, the Gini index is $63.1 \%$, reflecting the unequal distribution of gross revenue. In Chad, although the Gini index is relatively low (48.3\%) compared to Argentina and Mongolia, it remains above the national average (44.0\%). The main concern related to these high levels of inequality is that they can reflect asymmetric access to productive resources (basic infrastructures and services, natural resources, land use, etc.) and be a source of instability. It should be noted that self-consumption allows a reduction in the level of inequality.

Working with pastoral organizations, households in Chad and Argentina were presented with different shock scenarios and were asked to confirm or deny whether they had experienced one or more of these shocks over a predetermined period of time (the previous year for Chad and the last 15 years for Argentina). In Argentina, pastoralists report that most of the multifaceted shocks which they are facing affect the entire pastoral sector, and are thus covariate shocks (78\%) rather than household-level or idiosyncratic shocks (22\%). The reverse is true in Chad, where idiosyncratic shocks are the most reported at $51 \%$, with $43 \%$ being covariate shocks. The remaining $6 \%$ of shocks carried forward are attributable 
to a combination of various shocks. In this context of important shocks, households in both Argentina and Chad revealed that their most important strategies consist of strengthening their mobility by increasing the frequency and amplitude of livestock movements, and greater recourse to family labor to complement cattle herding and accompany this mobility. In parallel to these two most important strategies, households use complementary strategies, such as other forms of pastoral adjustments (animal sales) and the mobilization of social capital. However, it is worth noting that households never privilege recourse to official aid, thus showing that pastoral and agropastoral households seek to mobilize endogenous strategies based on their own system of actions rather than relying on third parties in the form of grants, subsidies and credits. 


\section{Key messages}

\section{1. (AGRO)PASTORAL ASSOCIATIONS GREATLY CONTRIBUTE TO THE COLLECTION OF RELIABLE AND ACCURATE DATA}

A lack of reliable data on the full contribution of livestock to the economy remains a great challenge for policymakers. It exacerbates the limited visibility of livestock sectors, thus weakening the argument that more resources should be invested in them. In addition, gaps in knowledge on the needs and future dynamics of pastoral systems lead to biased policies which do not consider the important role that these systems may continue to play for livestock development. In this context, (agro)pastoral associations representing pastoralists locally and regionally have a key role to play by contributing to the collection of reliable and accurate data. Through close and appropriate cooperation with these associations, it is possible and even desirable to use theoretical and methodological economic tools to analyze pastoral realities and put them in perspective with the rest of a national or even a sub-regional economy. The aim is to better integrate herders into the economic system, to which they already contribute by playing a key role in animal protein production and by implementing management practices adapted to environments in disequilibrium. Economic analyses to complement historical, sociological, and anthropological knowledge will enable policymakers to make more incisive and integrative decisions.

The pilot studies implemented in Argentina, Chad and Mongolia provide very promising results as (agro)pastoral associations showed a willingness to commit themselves and a real potential to handle multiple tasks on data collection and management. In addition, their role during policy dialogues was undeniably useful.

\section{2. (AGRO)PASTORALISTS USE MARKETS OF GOODS AND SERVICES AND THEY ENSURE THEIR FOOD SECURITY THROUGH PURCHASES AND SELF- CONSUMPTION, BUT THEIR ACCESS TO MARKETS IS CONSTRAINED BY WEAK ENABLING ENVIRONMENT}

Producers in extensive systems try to secure both their production and livelihoods over time within an overall context that is uncertain. The objective function of producers in extensive and pastoralist systems is a composite utility function that balances their shortterm consumption needs and long-term herd building strategy to meet future consumption as demonstrated by Fadiga (2009). For these reasons, they participate in markets in an opportunistic manner as shown by Wane et al. (2009a). Market fundamentals are not the primary drivers, but cultural, social, and non-commercial factors play a significant role in producers' decisions to sell. Valuing the production of pastoral households for their own consumption and food security becomes essential in view of its importance in pastoral systems. In addition, the systematic integration of this value into national accounts appears

equally important. Pastoralists know markets well, but markets do not always respond to their needs: inadequate infrastructure, price volatility and complex policy regulations result in a lack of an enabling environment in most pastoral areas. 


\section{3. (AGRO)PASTORAL HOUSEHOLDS GENERATE WEALTH AT THE MICRO LEVEL AND FOR NATIONAL ECONOMIES}

Most of the people living in extensive pastoral areas depend on natural resource-based livelihood activities, such as herding and farming, and their capability to generate wealth in a demand-driven context of livestock products is undeniable. They are able to generate wealth because their financial costs of production are relatively limited compared to the revenues provided by diverse sales sources.

Their real contribution to national economies remains poorly known because some aspects related, for example, to relatively high levels of self-consumption are not well addressed. The environmental costs of pastoral activities need to be better assessed from an economic point of view. Moreover, the annual nature of income measures and the multiannual nature of production costs make the assessment of the economic contribution somewhat more difficult to carry out. This complication can negatively impact the estimated contribution of pastoralists to national economies. However, it can be counterbalanced by the valuation of provisioning services provided by pastoral systems and thus fully integrate their multifunctionality in national accounts.

\section{ECONOMIC CONTRIBUTION OF (AGRO)PASTORAL HOUSEHOLDS IS THREATENED BY HIGH INEQUALITIES DUE TO ASYMMETRIC ACCESS TO PRODUCTIVE RESOURCES}

Widening income inequality is challenging (agro)pastoral systems around the world. The extent of inequality, its drivers, and what to do about it have become some of the issues most hotly debated by policymakers and researchers alike. The relationships between inequality, level of income and stage of development are widely analyzed in the economic literature. Quantitative measures of inequality become both scientific and political challenges for societies regardless of their level of social and economic development, as persistent inequality can threaten sectoral growth, cause investment-reducing political and economic instability, fuel social resentment, populism and protectionism, lead to political instability, and raise the risk of crises.

Scant attention has been paid to the importance of livestock activities, through livestock endowment and productive strategies, in the emergence of socioeconomic inequalities in rural societies. Moreover, the majority of the studies carried out in pastoral environments have had an anthropological basis and have postulated a form of social equality in pastoral societies. Pastoral societies often have been regarded as economically egalitarian in view of the random nature of pastoral activity conducted in an uncertain environment and the absence of differences in social status. However, previous measurements made in West and East Africa show strong levels of economic inequality (illustrated by high Gini coefficients). These trends can be observed in Argentina, Chad and Mongolia, where unequal distributions of gross revenue result from important disparities in land use and pose the problem of access to economic resources (natural resources, basic social services and infrastructure, etc.). 


\section{5. (AGRO)PASTORALISTS OPERATE IN A SHOCK-PRONE ENVIRONMENT. THEY TAKE ADVANTAGE OF IT, PRIORITIZING STRATEGIES BASED ON THEIR OWN RESOURCES: MOBILITY, FAMILY LABOR, ASSET SALES, ETC.}

The impacts of multifaceted shocks lead herders to seek adaptation and coping strategies in a shock-prone environment. In such a context, on the one hand they develop adaptation strategies as sustainable long-term strategies (for instance, mobility) that support an adjustment process to cope with current or expected shocks or to take advantage of potential opportunities (for instance, demand-driven context of livestock products). On the other hand, they also use vital and urgent coping strategies as short-term strategies that designate measures to address shocks without accurate planning (for instance, wage-labor of shepherds).

To dispel a myth, the pastoralists interviewed all rely primarily on their own family resources and social capital; they do not consider official support as a preferred strategy.

\section{IMPLEMENTATION OF THE OBSERVATORY OF (AGRO)PASTORALISM LEADING DATA GENERATION AND VISUALIZATION TOOL ON PASTORALISM}

The results of the studies carried out in the three countries identified the knowledge gap and above all the possibility of improving it through a relevant partnership in which pastoral organizations will have an important role to play in data collection and management. These findings indicate the need and relevancy to implement a socioeconomic and environmental observatory of (agro)pastoralism in each of the three target countries. The observatories will provide collaborative tools for information-sharing, analysis and decision support. Their aim is to present, compare and disseminate socioeconomic and environmental information on (agro)pastoralism.

On the whole, a standard observatory will consist of some basic platforms: a system that aims to characterize and map information through innovation platforms to involve all stakeholders in (agro)pastoral livestock production, including pastoral organizations, in a participatory way; technological platforms to allow relevant information to be received in or near real-time; and simulation platforms to describe major socioeconomic and environmental trends. The objective would be to combine all of these platforms to facilitate simulation, visualization and participation for the detection and mitigation of environmental and socioeconomic crises, as well as the identification of opportunities for improving production systems and livelihoods of (agro)pastoral and livestock stakeholders. In so doing, the observatories should facilitate the implementation of a network of partners dedicated to the development of (agro)pastoralism through the cross mobilization of information and the construction of adapted and appropriate knowledge while favoring the monitoring of changes in (agro)pastoralism, which allows the capitalization of information on the system from a given time. 



\section{Introduction}

Pastoralism is a global phenomenon. Due to its complexity, it is not easy to provide a comprehensive definition of this polysemous notion. From an economic perspective, pastoral production systems may be defined as those in which at least $50 \%$ of gross household income comes from pastoralism or related activities. In other words, pastoralists are people who earn more than $50 \%$ of their income from livestock and livestock products derived from rangeland resources. This strict definition can help to distinguish pastoralists from agro-pastoralists, who derive less than $50 \%$ of their income from animals and animal products and most of the remainder from crop cultivation as demonstrated by Swift (1979).

However, a more realistic definition would go beyond this economic perspective by incorporating other important sociocultural and ecological dimensions. Pragmatically, we can consider pastoralism as mobile livestock herding in the dimension of either production or livelihood.

Overall, pastoralism is an animal production system that covers some $25 \%$ of the world's land area as demonstrated by Blench (2001). Pastoralists produce food in the harshest environments, but traditionally suffer from being poorly understood, marginalized and excluded from policy dialogues. Pastoral production systems are characterized by their complexity and a structurally asymmetric distribution of resources.

These systems are structured by strong interactions between ecological, social and economic processes, requiring genuine transdisciplinary approaches. The PKH is an initiative bringing together pastoralists and the main actors working with them to join forces and create synergies for dialogue and pastoralist development.

As part of this initiative, CIRAD was commissioned by FAO to provide technical and scientific support to a pastoralist-driven data management system project aiming to analyze pastoral household economies and assess their economic contribution to national economies. More specifically, CIRAD led the analysis of the economics of pastoralism and the contribution of pastoralism to the GDP in three target countries: Argentina, Chad and Mongolia.

Based on permanent interactions with pastoral organizations and primary data collection, the survey was organized around an overall synthesis of approaches and methods adapted to the particular context of pastoral activities in the three target countries. For each of these countries, analyses were then carried out concerning revenue generation, revenue distribution, operational costs, direct economic contribution, the economic function of self-consumption, and strategies used by pastoralists to cope with multifaceted shocks. The study also identified key messages in the form of policy implications appropriate to the characteristics of pastoralism in the target areas. 


\section{STRONG RECOGNITION OF THE KNOWLEDGE GAPS}

The challenge for poor countries with sizable livestock systems in general, and pastoral systems in particular, lies in finding a way to foster more efficient modes of production that meet increasing demand for livestock products while minimizing adverse impacts on the environment and human health and improving the well-being and nutrition of smallholder farmers.

Several pathways can lead to growth in the animal production sector, including genetics, improved animal nutrition and disease control, mitigation of environmental risks, and development of markets and infrastructures. Each country's livestock trajectory will depend on its particular economic, social and institutional characteristics as it has been demonstrated (Thornton, 2010). Whatever the path undertaken, policymakers will face a number of key tradeoffs between competing objectives - e.g., economic development, environmental sustainability, improvements in rural livelihoods, export revenues and/or food security - which will require availability, access to, and utilization of the best data and methods available.

A lack of data and low quality and unreliable data inhibit the development of effective livestock and pastoral policies. In their paper, "Investing in the livestock sector: Why good numbers matter?", Pica-Ciamarra et al. (2014) argue that livestock and pastoral data collection in developing countries is conducted irregularly and with inappropriate methods, thus missing the opportunity to obtain a reliable baseline for policy formulation. The data that is available to policymakers is usually outdated and scattered. Due to the absence of appropriate methodologies and a lack of consistency between sources and over time, the data that does exist is hard to compare, combine or analyze.

Multiple knowledge gaps limit the potential for policies to address key constraints affecting livestock and pastoral sectors in the most vulnerable livestock producing countries in Africa and Asia. Empirical analyses of the economic contributions of animal production systems mostly focus on isolated aspects. Several studies in different parts of Africa have, for instance, measured the important effects of livestock sectors on household revenue generation (Little et al., 2001; Wane et al., 2009a), poverty reduction (Pica-Ciamarra, 2005; Alary et al., 2011), sectoral job creation (Wane et al., 2018a), and inter and intra-household inequality reduction (Little et al., 2001; Wane et al., 2009b).

However, comprehensively measuring and modeling animal production systems and their contributions to national or regional wealth creation remains a challenging task. The main knowledge gaps include: lack of accurate and appropriately disaggregated data on livestock and pastoral production systems; evaluation tools that focus on intensive and commercialized animal production systems while disregarding the informal production systems and markets where most transactions occur; and underestimation of indirect effects from livestock (Hatfield and Davies, 2007 cited by Krätli, 2014).

Ignoring the complex and multiple functions of livestock can lead to a serious underestimation of their real contribution to overall national wealth creation. Indirect contributions from livestock include animal traction, manure and self-consumption of animal products. In addition, pastoral systems provide essential, but insufficiently documented, environmental services, such as biomass production, biodiversity and water cycling, as well as beneficial social impacts.

Several studies have attempted to overcome the above limitations to obtain a reasonable estimate of the contribution of livestock to GDP, making significant progress in 
understanding the economic significance of livestock. In the Sahel, livestock products are an engine of growth and the main vector of regional integration (Inter-Réseaux, 2018). In Mali, livestock contributes about $19 \%$ of the country's GDP, and represents the third largest export commodity after gold and cotton (World Bank, 2017). In Mauritania, a sectoral study initiated in 2001 by authorities of the country, the World Bank and FAO, showed that livestock farming generated $15 \%$ of the GDP, $75 \%$ of the agricultural GDP, and $68.2 \%$ of value added in the rural sector (FAO, 2002). The same FAO study assessed the role of capitalization and livestock insurance, especially for the poorest households, as well as the contribution of livestock in terms of fertilizer and transportation services. Livestock was found to contribute $24 \%$ of household food energy needs, including $4 \%$ of protein needs and $84 \%$ of lipid requirements. In Eswatini (formerly Swaziland), the beef value chain is estimated to contribute $32 \%$ to the agricultural GDP, and $2 \%$ to the GDP, with positive impacts on public finances but a negative impact on the balance of trade (Wane et al., 2018b). In Sudan, livestock and pastoral activities generated between USD 14.5 billion and 12.3 billion in 2009 (Behnke and Osman, 2011). In Ethiopia, they provided 80\% of exports and a return on investment of between 25 to 30\% per year (Behnke and Metaferia, 2011). In Kenya, pastoral systems comprised $70 \%$ of herds, with a market value estimated at USD 800 million (Republic of Kenya, 2012), and provided $80 \%$ of the beef consumed in 2009 (Behnke and Muthami, 2011); while in southwestern Uganda, the pastoral system yielded a financial return per hectare of land that was 6.8 times higher than that of the ranching system (Ocaido et al., 2009).

Overall, although important improvements have been made in the measurement of livestock's contribution to GDP, knowledge gaps remain and will require continued efforts to expand this type of work across time and to other low and middle-income countries with substantial livestock sectors. Substantial financial and institutional support will need to be mobilized to allow for costly data collection and calculation. Furthermore, a full and comprehensive accounting of GDP will require a change in paradigms and techniques to allow the overlapping and interdependent contributions of livestock to be captured, and to move away from current methods, which mainly view actors and livelihoods as neatly compartmentalized. Finally, global changes (climate, price variability) and structural constraints imply the need to work at different spatial-temporal scales, considering in situ and off-site effects, and over a span of several years, in order to obtain representative figures.

\section{THE USE OF APPROPRIATE CONCEPTS, APPROACHES, AND METHODS}

To produce data and knowledge on pastoral systems, we adapted concepts, approaches and methods to the intrinsic characteristics of pastoralism. We considered in particular the diverse activities undertaken by pastoralists, as well are their social and geographic context. Pastoralists in Argentina, Chad and Mongolia have developed adaptive behaviors to make a living in very harsh environments by keeping a mixture of species and various traditional breeds: cattle, camels, goats, sheep, yaks, horses, donkeys, llamas, and alpacas. Keeping more than one species allows herders to produce a wider variety of products and manage the asymmetric distribution of natural resources over the year, and in particular during crisis periods. Some pastoral herders are also involved in cultivation, farm products marketing, and other non-farming activities. In addition, most economic 
transactions are conducted in an informal manner, as is the case for instance for social transfers.

The main concepts used in this study are revenue, expenditure and the direct economic contribution of pastoral households, in a static approach within an annual time horizon so that comparisons can be made with more standard indicators such as GDP. A more dynamic approach also was used more specifically in Argentina and Chad to analyze the multifaceted shocks that pastoral households face and the strategies that they use in priority to deal with vulnerability factors.

\section{Conceptual framework for pastoral household revenue analysis Definition of household revenue (ILO, 2003)}

Household revenue consists of all receipts whether monetary or in-kind (goods and services) that are received by the household or by individual members of the household at annual or more frequent intervals, but excludes windfall gains and other such irregular and typically one-time receipts. Household revenue receipts are available for current consumption and do not reduce the net worth of the household through a reduction of its cash, the disposal of its other financial or nonfinancial assets or an increase in its liabilities.

Household revenue may be defined as covering: (i) revenue from employment (both paid and self-employment); (ii) property revenue; (iii) revenue from the production of household services for own consumption; and (iv) current transfers received.

The terms revenue and income are conceptually different. "Revenue" is the total amount of earnings generated by the sale of goods or services related to primary operations. The "revenue number" is the revenue an economic actor generates before any expenses are taken out. "Income", or "net revenue", is total earnings or profit. Net revenue is calculated by taking revenues and subtracting the costs of doing business, such as depreciation, interest, taxes, and other expenses. Therefore, we favor the use of the term "revenue" to analyze the primary sources of monetary and non-monetary receipts. Pastoralist households derive their revenue from five main sources: 1) agricultural activities: often food crops (cereals, vegetables); 2) livestock products: live animals, meat, dairy products, fibers for textile (e.g., cashmere), hides and skins; 3 ) services to other economic activities and sectors to earn salaries in agriculture (farm labor), animal husbandry (shepherd), trade, education, and other service activities; 4) transfers: remittances and/or loans from various sources: government; and 5) production for own use, usually called self-consumption (Figure 1).

\section{Conceptual framework for pastoral household expenditure analysis Definition of household expenditure (ILO, 2003)}

Consumer goods and services are those used by a household to directly satisfy the personal needs and wants of its members. Household consumption expenditure is the value of consumer goods and services acquired, used or paid for by a household through direct monetary purchases, own-account production, barter or as revenue in-kind for the satisfaction of the needs and wants of its members. Household expenditure is defined as the sum of household consumption expenditure and the non-consumption expenditures of the household. The latter are those expenditures incurred by a household as transfers made to government, non-profit institutions and other households, without acquiring any goods or 
FIGURE 1

Conceptual framework for household revenue analysis

Overall revenue of (agro)pastoralists
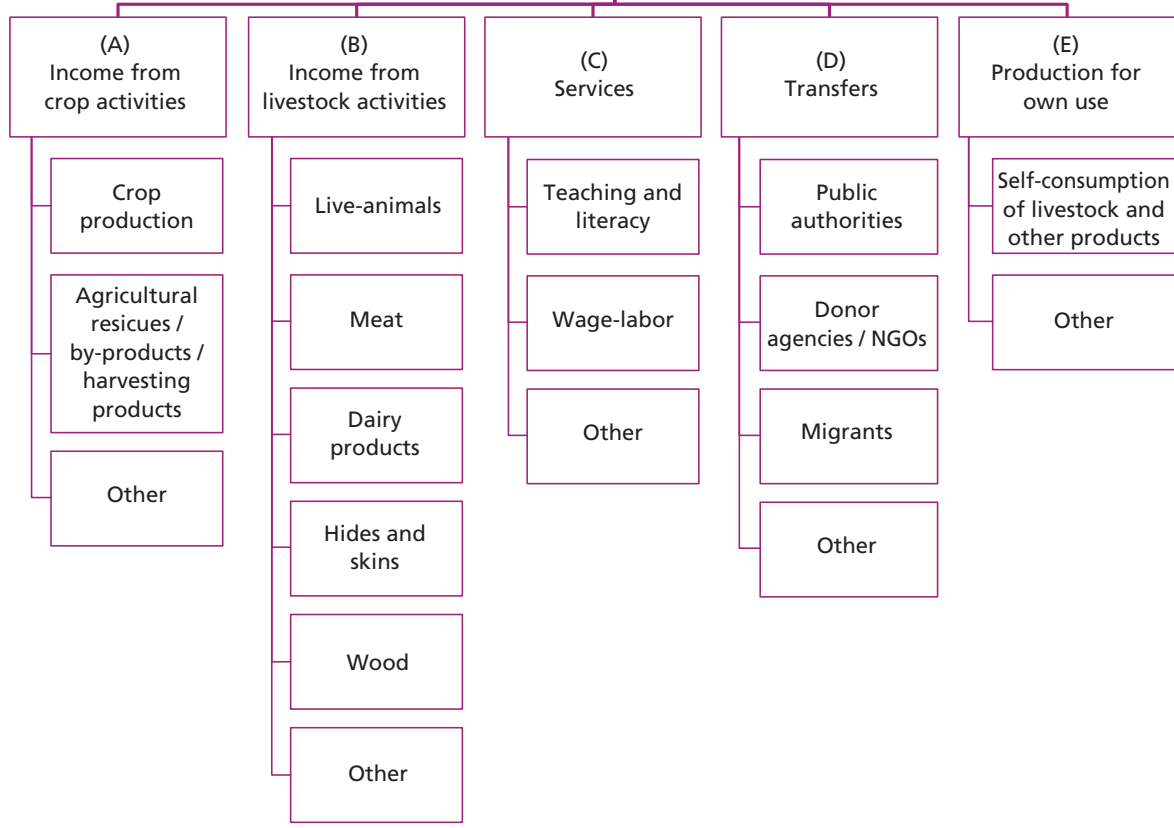

Source: Authors.

services in return for the satisfaction of the needs of its members. Household expenditure represents the total outlay that a household has to make to satisfy its needs and meet its "legal" commitments.

Expenditures of pastoral households are spent on food and non-food items (Figure 2).

From our perspective, to determine the economic contribution of pastoral households by using a value-added or production approach, we shifted the previous classification to distinguish two types of multi-year running costs:

- costs that intervene directly in the production process (purchase costs of products sold and intermediate consumption);

- other multi-year running costs of pastoral households (Figure 3).

\section{Conceptual framework for shocks and strategies analysis}

Risks are a central part of life for most households, and in particular for rural populations in low-income countries (Banerjee and Duflo, 2011). Better understanding risks and associated coping strategies is key for policymakers. The main challenge of risk analysis at the household level is that the presence or perception of risk can significantly affect the intertemporal behavior of households in the allocation of their resources. This can affect both 
FIGURE 2

Conceptual framework for pastoral household food and non-food expenditure analysis

Expenditures of (agro)pastoralists

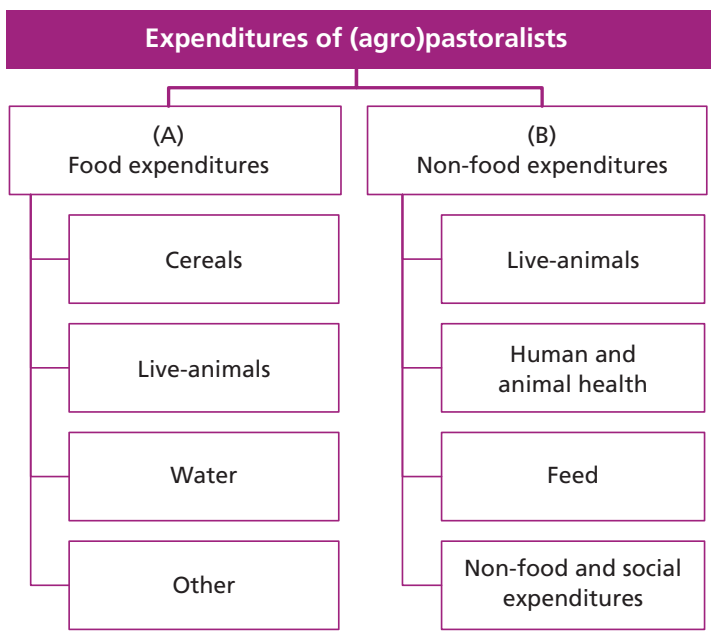

Source: Authors.

FIGURE 3

Conceptual framework for direct production and non-production cost analysis

Expenditures of (agro)pastoralists

(A)

(B)

Direct production costs

Non-direct production costs

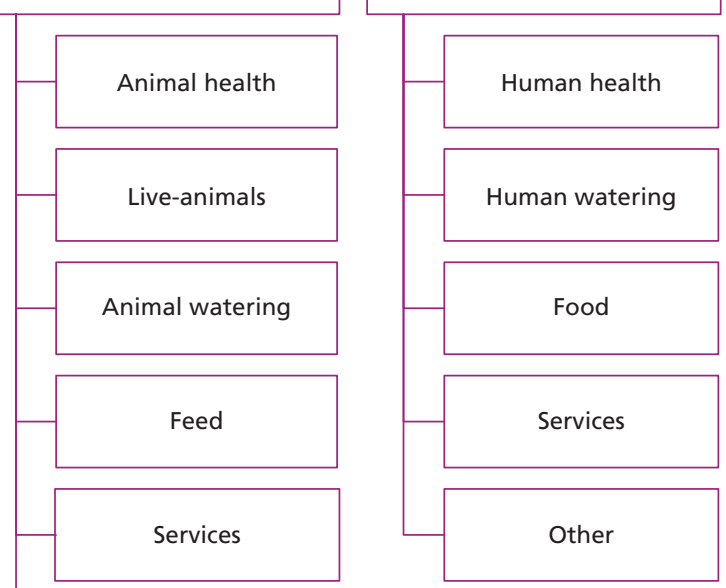

Other

Source: Authors. 
poor and non-poor households, as the probability of the latter becoming poor is higher than in safer environments. Hazards are ubiquitous in the lives of most farmers in developing countries, who must act to secure their livelihoods and minimize losses. Those with weak assets are usually pushed to engage in low return and sometimes risky non-farming activities (Barrett et al., 2001), whereas for those who are better endowed or living in regions with favorable alternative activities, the impetus to raise revenues and accumulate wealth prevails (Loison and Loison, 2016).

Pastoralists live and operate in a shock-prone environment (Wane et al., 2010). Climate variability plays a central role by having a direct impact on natural resource dynamics, pushing herders to deal with spatiotemporal variations. Climate change is also a factor that aggravates economic, social, cultural and political disturbances (price volatility of food and feed at national and international levels, disease, political instability, social transformations, etc.). Pastoralists also face a lack of infrastructure and market uncertainties, which severely affects their livelihoods. They adapt their activities to these conditions by using mobility and diversification strategies to enhance production and secure their livelihoods (Alary et al., 2015). These strategies are characterized by complex relations that limit the kind of strategies possible and by the multifunctionality of livestock assets. Sometimes pastoralists engage in breeding livestock species with short life cycles, which provide fast gains to escape poverty (Alary et al., 2015). In other context, they favor large ruminants that represent a long-term capital investment (Wane et al., 2010)

It should be noted that in a risky context, holding animals beyond a non-optimal marketing period corresponds to a form of contingency rationality. Imperfect and incomplete information in markets encourage pastoralists to adopt a prudent position, adapted to the circumstances and therefore contingent on their socioeconomic environment (Wane, 2005; Wane et al., 2010). This explains why pastoralists are not in favor of regular animal "destocking" even if technical services encourage them to do so. Far from being indifferent to the level of market prices (Kerven, 1992), livestock farmers make tradeoffs between their short-term consumption needs and long-term herd building strategy to meet future consumption (Fadiga, 2009).

In this context, pastoral and agropastoral households develop adaptation and coping strategies that reflect a repertoire of responses to stress. They have these available and can use them more or less successfully. These multiple responses illustrate the close embeddedness between social and biophysical factors. Extensive systems cannot be measured purely in terms of endowments as they continually evolve and adapt to accommodate an increasingly uncertain biophysical environment and monetized world (Chambers, 1989; Van Dijk, 1997; Bovin, 2000; Ancey et al., 2009).

Through the intermediary of pastoral organizations, households in Chad and Argentina were presented with different shock scenarios and were asked to confirm or deny whether they had experienced one or more of these shocks over a predetermined period of time (the previous year for Chad and the last 15 years for Argentina). The households then classified the shocks according to their severity: most severe, second-most severe and third-most severe. Finally, several options for adaptation and/or coping strategies were presented to the same households, which then ranked the various strategies according to their importance: most important, second-most important or third-most important. Every household 
that experienced production, economic or social losses had adopted at least one adaptation or coping option during the period of reference.

The analysis of shocks reported by pastoral and agropastoral households allows covariate and idiosyncratic shocks to be distinguished.

A covariate shock (drought or rising food prices) refers to a shock that affects an entire community or region.

An idiosyncratic shock (death of a household member or illness) refers to a shock affecting only one household or a limited number of households. However, a shock may have characteristics that are unique to both groups.

\section{Conceptual framework for assessing the contribution of pastoralists to national economies}

According to the Organisation for Economic Co-operation and Development (OECD), ${ }^{3}$ the GDP is an aggregate measure of production equal to the sum of the gross values added of all resident institutional units engaged in production (plus any taxes, and minus any subsidies, on products not included in the value of their outputs). It is the sum of the final uses of goods and services (all uses except intermediate consumption) measured in purchasers' prices, minus the value of imports of goods and services, or the sum of primary incomes distributed by resident producer units.

GDP measures the monetary value of final goods and services - that is, those that are bought by the final user - produced in a country in a given period of time (say a quarter or a year). It counts all of the output generated within the borders of a country. GDP is composed of goods and services produced for sale in the market and also includes some non-market production, such as defense or education services provided by the government.

Not all productive activity is included in the GDP. For example, unpaid work (such as that performed in the home or by volunteers) and black-market activities are not included because they are difficult to measure and value accurately.

Moreover, "gross" domestic product takes no account of the "wear and tear" on the machinery, buildings, and so on (the so-called capital stock) that are used in producing the output. If this depletion of the capital stock, called depreciation, is subtracted from the GDP, the net domestic product is obtained (Callen, 2016).

Despite its intrinsic limitations and biases, the GDP is the most common indicator used to describe a country's economic performance and economic growth, and provides a way to measure the relationship between total resource inputs and total economic outputs. Several approaches are used to calculate the GDP:

\section{- Value-added or production approach}

This measures the output of all economic sectors. More specifically, under this approach, the GDP equals the value of all goods produced in all sectors minus the value of all purchased intermediate goods used for production (i.e. intermediate consumption).

\section{- Revenue approach}

This method focuses on the sum of primary revenues (from labor, capital, land, and profit) to estimate the GDP. The idea behind this is that firms need to hire factors of

3 (https://stats.oecd.org/glossary/detail.asp?ID=1163). 
production to create all goods and services, thus the sum of primary revenues can be used as an indicator of economic output. In particular, all revenues from labor, rent, and interest, as well as remaining profits, have to be summed up to calculate national revenue. Adding indirect business taxes, depreciation, and net foreign factor revenue to the calculated national revenue will finally result in the GDP.

\section{- Expenditure approach}

This represents a counterpart to the revenue approach, as it measures total spending on final goods and services (as opposed to earnings from them). At this point it becomes quite obvious why the different approaches should result in the same GDP value: according to the circular flow of revenue, economic expenditure by one party is ultimately always revenue for a different party. Thus, to calculate the GDP using the expenditure approach, all economic activities that result in the use of goods or services have to be added up. In particular, that includes private consumption, total investment, government spending, and net exports (exports - imports).

In this exploratory study, we used the value-added or production approach to determine the economic contribution of pastoral systems in Argentina, Chad and Mongolia through the gross value added (GVA). We calculated the GVA of the pastoral and agropastoral households in the three target countries by sector. The GVA is calculated as total output value minus intermediate consumption (variable inputs). It represents the part of revenue that is left to pay for fixed production factors (land, labor, capital) and to serve as revenue for the farmers and non-salaried workers (usually members of the farmer's family). We determined the value added at the level of each pastoral site studied and aggregated it at the national level. We then compared the values obtained to the national GDP and to the agricultural GDP.

Although self-consumption is a critical non-market output in agropastoral systems, it is not included in standard measures of GDP. This is an important omission that should be urgently rectified. We therefore decided to consider the value of self-consumption in our study.

Furthermore, in the livestock sector, revenue can be assessed yearly, but actors incur multi-year direct production costs. In order to reflect these multi-year logics of pastoral production systems and the importance of self-consumption, we developed the following three GDP calculation scenarios:

- GDP calculation scenario 1 represents a standard calculation of the direct economic contribution that does not include self-consumption. The idea is to disregard some non-market elements (such as self-consumption).

- GDP calculation scenario 2 considers the incorporation of self-consumption in the calculation method. Household production for self-consumption is an item of high interest given its central strategic role in pastoral household food security, it therefore would be key to consider it.

- GDP calculation scenario 3 considers the average amount of time animals are kept prior to being sold to consider multi-year intermediate costs. The objective is to illustrate the hidden overall cost of the duration of animal ownership. Indeed, the longer a household keeps animals in its herd for various reasons, including the management of uncertainties, the less significant will be its contribution to the 
national economy. Interviews with pastoralist associations in Argentina and Chad noted that cattle are kept for an average of 4-5 years before being put on the market, sheep for 1-1.5 years and goats for 1 year. In a very simple way, we simulate different holding periods to analyze repetitive production costs and potential impacts on the real contribution of pastoralists to GDP. By analogy with the different forms of capital, the various types of livestock can be assimilated, depending on the situation, to cash, insurance and assets, hence livestock marketing decisions are "measured" in terms of the number of animals sold as well as the duration of time animals are held before being sold.

\section{Sampling strategy in Argentina, Chad and Mongolia}

Data collection in pastoral areas remains challenging. Very few countries have official agricultural data that is disaggregated to show the contribution of pastoralism to the agricultural GDP. Gaps remain in empirical records, particularly in countries that have suffered extended periods of conflict, and in countries that have lacked a capacity to collect, process, and publish statistics. Even in areas for which data are available, the data do not cover all relevant topics. Mindful of the limitations of currently available socioeconomic data, the survey benefited from the strong commitment of pastoral associations that have been trained to effectively handle data collection in the target areas. Several training sessions were provided by CIRAD at the country level and remotely as well, notably on approaches to gathering information and developing appropriate tools.

Particular attention was paid to observing general requirements for sampling and statistical analysis. The objective was to define a sample as a percentage of the total population so that it would be possible to make statistical inferences.

Long and fruitful work of identifying the pastoral population was carried out with a pastoral association as our main partner in each of the target countries. A triangulation with available national statistics also was conducted.

Two sampling targets were set based on the capacity of the pastoral associations to carry out the surveys within the existing time and cost constraints. The main technical constraint was to remain within a margin of error of less than $5 \%$ in accordance with standard statistical approaches. Finally, we analyzed data collected on 1197 pastoral households in Argentina, 803 in Chad and 764 in Mongolia (Table 1).

TABLE 1

\section{Sampling size determination}

\begin{tabular}{lccc}
\hline Country & $\begin{array}{c}\text { Target sample } \\
\text { Scenario 1 }\end{array}$ & $\begin{array}{c}\text { Target sample } \\
\text { Scenario 2 }\end{array}$ & $\begin{array}{c}\text { Final } \\
\text { sample size }\end{array}$ \\
\hline Argentina & $\begin{array}{c}1100 \text { households } \\
(\mathrm{e}=2.54 \%, \mathrm{ci}=95 \%, \mathrm{p}=50 \%)\end{array}$ & $\begin{array}{c}500 \text { households } \\
(\mathrm{e}=4.12 \%, \mathrm{i}=95 \%, \mathrm{p}=50 \%)\end{array}$ & $\begin{array}{c}1 \text { 197 households } \\
(\mathrm{e}=2.83 \%, \mathrm{ci}=95 \%, \mathrm{p}=50 \%)\end{array}$ \\
\hline Chad & $\begin{array}{c}11067 \text { households } \\
(\mathrm{e}=3.00 \%, \mathrm{ci}=95 \%, \mathrm{p}=50 \%)\end{array}$ & $\begin{array}{c}800 \text { households } \\
(\mathrm{e}=3.46 \%, \mathrm{ci}=95 \%, \mathrm{p}=50 \%)\end{array}$ & $\begin{array}{c}803 \text { households } \\
(\mathrm{e}=3.46 \%, \mathrm{ci}=95 \%, \mathrm{p}=50 \%)\end{array}$ \\
\hline Mongolia & 1800 households & $\begin{array}{c}803 \text { households } \\
(\mathrm{e}=2.31 \%, \mathrm{ci}=95 \%, \mathrm{p}=50 \%)\end{array}$ & $\begin{array}{c}764 \text { households } \\
(\mathrm{e}=3.46 \%, \mathrm{ci}=95 \%, \mathrm{p}=50 \%)\end{array}$ \\
\hline
\end{tabular}




\section{Household characterization in Argentina, Chad and Mongolia}

The household, the subject of this survey, can be defined as a group of persons who make common provision for food, shelter and other essentials for living. It is a fundamental socioeconomic unit in human societies. Households are the centers of demographic, social and economic processes. Key decisions, particularly in rural areas, occur primarily at the household level.

The size of a typical household varies: it is larger in Chad (on average 5.8 members) compared to Argentina and Mongolia (3.3 and 3.6 members, respectively). A more disaggregated view confirms the overall trends: in Argentina $42 \%$ of households are made up of 2-3 members, in Mongolia $40 \%$ of households have 3-4 members, and in Chad $48 \%$ of households assemble more than 6 members.

The presence of children in a household has major implications for the household's priorities, particularly with respect to the demand and allocation of resources for education and health care. Chad and Mongolia are characterized by the youthfulness of their populations, with more than three-quarters of households having at least one child under the age of 15. The phenomenon is more pronounced in Chad. In comparison, less than half of households in Argentina have children under the age of 15.

Female-headed households are most common in Argentina (28\%), followed by Chad $(22 \%)$, and Mongolia (17\%). The percentage of households including an older person also depends on other factors such as the living arrangements of older persons.

\section{TABLE 2}

\section{Household characterization in the three target countries}

\begin{tabular}{|c|c|c|c|c|c|c|c|c|}
\hline \multirow[b]{2}{*}{ Country } & \multirow{2}{*}{$\begin{array}{c}\begin{array}{c}\text { Average } \\
\text { household } \\
\text { size }\end{array} \\
\\
\\
\text { Total }\end{array}$} & \multicolumn{4}{|c|}{$\begin{array}{l}\text { Distribution of households } \\
\text { by number of members (\%) }\end{array}$} & \multicolumn{2}{|c|}{ Headship (\%) } & \multirow{2}{*}{$\begin{array}{c}\begin{array}{c}\text { Lone female } \\
\text { headship with } \\
\text { children (\%) }\end{array} \\
\begin{array}{c}\text { Share of female- } \\
\text { headed households }\end{array} \\
\text { who are lone parents } \\
\text { with children under } \\
\text { age } 15\end{array}$} \\
\hline & & 1 & 2 to 3 & 4 to 5 & $6+$ & Female & $\begin{array}{c}\text { Older } \\
\text { person } \\
(60+)\end{array}$ & \\
\hline Argentina & 3.3 & 18 & 42 & 29 & 11 & 28 & 29 & 25 \\
\hline Chad & 5.8 & 8 & 18 & 26 & 48 & 22 & 17 & 70 \\
\hline \multirow[t]{2}{*}{ Mongolia } & 3.6 & 6 & 27 & 40 & 27 & 17 & 14 & 56 \\
\hline & $\begin{array}{l}\text { Average } \\
\text { household } \\
\text { size }\end{array}$ & \multicolumn{4}{|c|}{$\begin{array}{l}\text { Households with children } \\
\text { or older persons (\%) }\end{array}$} & \multicolumn{3}{|c|}{ Households with children under age 15 (\%) } \\
\hline Country & Total & $\begin{array}{c}\text { With } \\
\text { children } \\
\text { under } \\
\text { age } 15\end{array}$ & $\begin{array}{c}\text { With } \\
\text { members } \\
\text { aged } 60+\end{array}$ & $\begin{array}{l}\text { With both } \\
\text { children } \\
\text { under age } \\
15 \text { and } \\
\text { members } \\
\text { aged } 60+\end{array}$ & $\begin{array}{c}\text { Average } \\
\text { number } \\
\text { of children } \\
\text { under } \\
\text { age } 15\end{array}$ & $\begin{array}{c}\text { Two } \\
\text { parents } \\
\text { present }\end{array}$ & $\begin{array}{c}\text { One } \\
\text { parent } \\
\text { present } \\
\text { (mother) }\end{array}$ & $\begin{array}{l}\text { One parent present } \\
\text { (father) }\end{array}$ \\
\hline Argentina & 3.3 & 48 & 34 & 7 & 2.1 & 78 & 19 & 2 \\
\hline Chad & 5.8 & 84 & 21 & 16 & 3.7 & 74 & 20 & 9 \\
\hline Mongolia & 3.6 & 75 & 20 & 10 & 2.1 & 77 & 20 & 4 \\
\hline
\end{tabular}

Sources: Household Size and Composition Around the World 2017, United Nations - Economic and Social Affairs. 
In the three countries, the median proportion of two-parent households is $77 \%$ among households with children under 15 years of age. The median proportion of one-parent households (among those with children) is much lower, at 20\% for lone-mother households and 4\% for lone-father households (Table 2). 


\section{Argentina}

\section{BACKGROUND AND MACRO CONTEXT}

One of the largest economies in Latin America, Argentina depends on services and manufacturing, although agribusiness and ranching dominated the economy up to the $20^{\text {th }}$ century. In the region, Argentina is the leading cereal producer and the second largest livestock country after Brazil.

Argentina has been going through a period of profound economic and social uncertainty. The GDP contracted to reach USD 445 billion (-2.5\% in real terms) in 2019 and USD 443 billion (-3.1\% in real terms) in 2020. A slow recovery is expected from 2021, and the country is expected to reach USD 580 billion in 2024, still below the level observed in 2018 (USD 643 billion) (Figure 4).

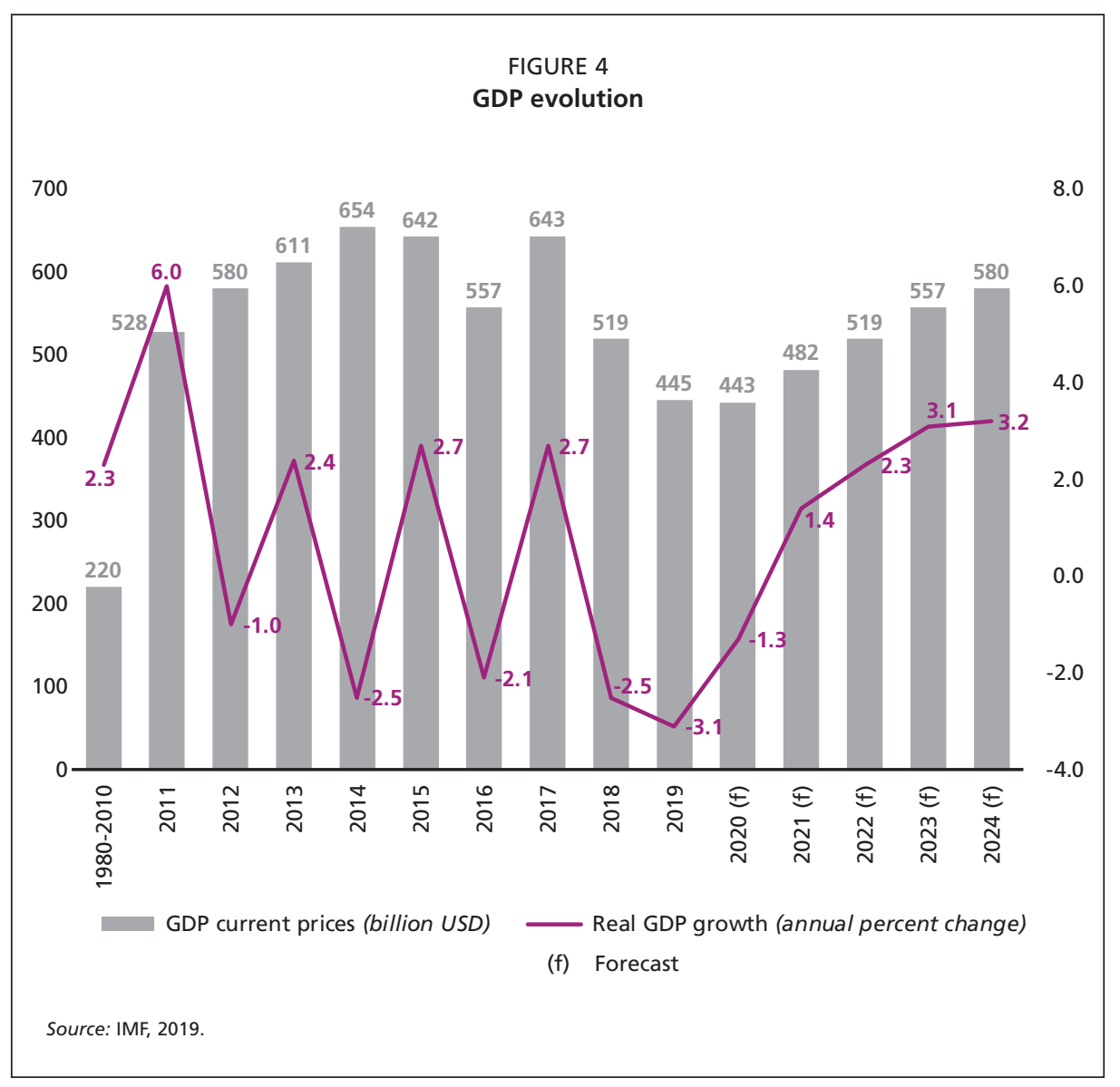




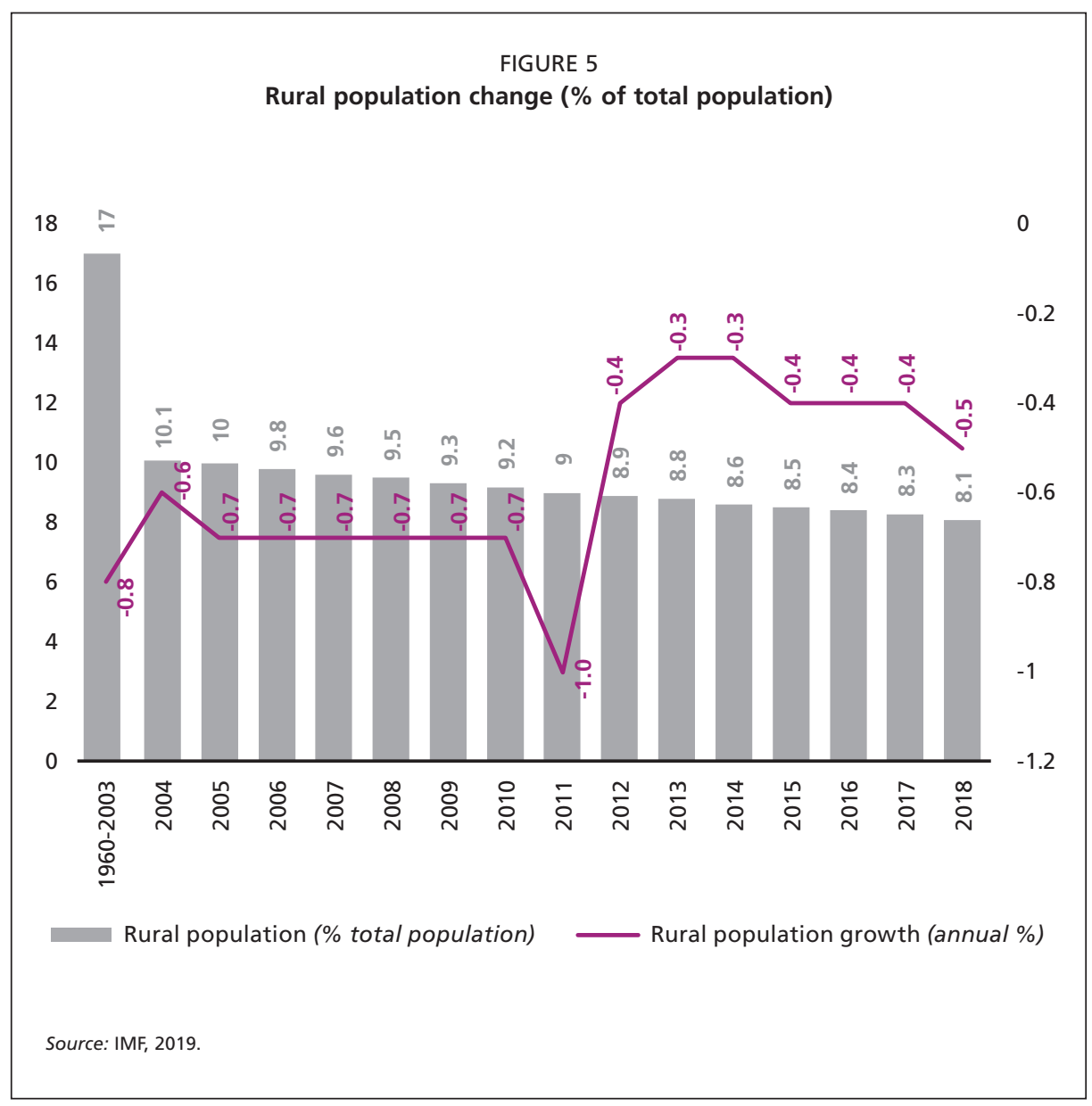

The country withstood a number of economic depressions, but these disturbances resulted in very precarious economic and social imbalances in 2019: the currency has been collapsing since April 2018 to a degree unseen for the past 18 years; the inflation rate (average consumer prices) is $54.4 \%$; the unemployment rate is $10.6 \%$; the current balance account is $-1.2 \%$ of GDP; the gross public debt is $93.3 \%$ of GDP; and the Human Capital Index is 0.61 (World Development Indicators, 2019).

These economic downturns have led to highly volatile macroeconomic and trade policies that also affected the agricultural sector. The emergency revenue measures implemented by the Argentinian authorities (export tax of $12 \%$ including agricultural products) hindered the performance of the primary sector. This situation could exacerbate the shrinking of the rural population, which fell from 17.0 to $8.1 \%$ of the total population between 1960 and 2018 (Figure 5).

Argentina vacillated between open economic and economic isolation approaches to finally focus on the whole value chain approach from 2015, with a strong decentralization of extension services. According to OECD (2019), the policy uncertainty potentially led to a lack of an enabling environment and boosted the production of commodities 
requiring less investment and working capital (such as soybean) to the detriment of more capital-intensive production (such as livestock). In addition, the livestock sector has experienced an important decline in bovine meat production, which fell from 3.0 to 2.6 million tons between 1990 and 2016 due to disincentive policies (export ban, taxes and volatile measures) that favored short-cycle crop production. The livestock sector did not really benefit from the growth of total factor productivity in the primary sector. The introduction of new technologies in crop production has had a positive impact in that sector, yet livestock production continues to stagnate. This situation illustrates the double structural duality observed in Argentina: duality between the Pampas and other regions, and duality between crop and animal production. More specifically, the perception of a country that is very well-endowed with natural resources hides strong heterogeneity in the distribution of resources, farming systems and livelihoods across the country. That is the case of pastoralism and pastoralists in Argentina, for which there is an urgent need to produce useful knowledge for decision-making.

\section{DATA COLLECTION AND MANAGEMENT: INCLUSIVENESS OF PASTORAL ORGANIZATIONS}

In Argentina, pastoralism is usually considered as a marginal production system carried out in medium and high mountain areas and dry forests. The difficulty of defining pastoralism is highlighted by growing trends which are challenging how pastoralism is usually understood. In the three zones where pastoralism is supposed to be exercised - Gran Chaco, Puna and Patagonia - the phenomena of deforestation, growing agricultural fronts, ranching, increasing mining activities, emigration, and land grabbing are threatening pastoralism as a production system and source of livelihoods. This subsistence activity therefore could go into a decline if no protection policies are implemented (Grünwaldt et al., 2016). Indeed, pastoral populations in Argentina have very limited access to technology and infrastructure. Their visibility in Argentinean society also remains low, and they are under-represented in national policies.

In this context of a gap in knowledge about the recent and future trends of pastoralism, FAO and CIRAD have supported the Gran Chaco Foundation as a local partner in Argentina to carry out a pastoralist-driven data management project. Created in 2000, the Gran Chaco Foundation is an NGO that develops activities in the Argentinean Gran Chaco area to support local initiatives from a technical point of view and to stimulate artisanal production. It is leading the recently established regional pastoralist association of Latin America, "PastorAmericas". This organization has been chosen to handle the data collection process. As such, it organized capacity-building activities on the use of FAO data collection software with pastoralists' organizations, established contact with FAO for the progress of the project and provided information to CIRAD. Collaboration with this NGO has facilitated access to field areas and the organization of meetings and has contributed to the process of making the collection of information on pastoralists in Argentina more reliable.

The Gran Chaco Foundation helped to thoroughly investigate 1197 pastoral and agropastoral households in the Northwest, Chaco, Cuyo and Patagonia regions in Argentina (Map 1). 
MAP 1

Spatial distribution of sample investigated households in Argentina

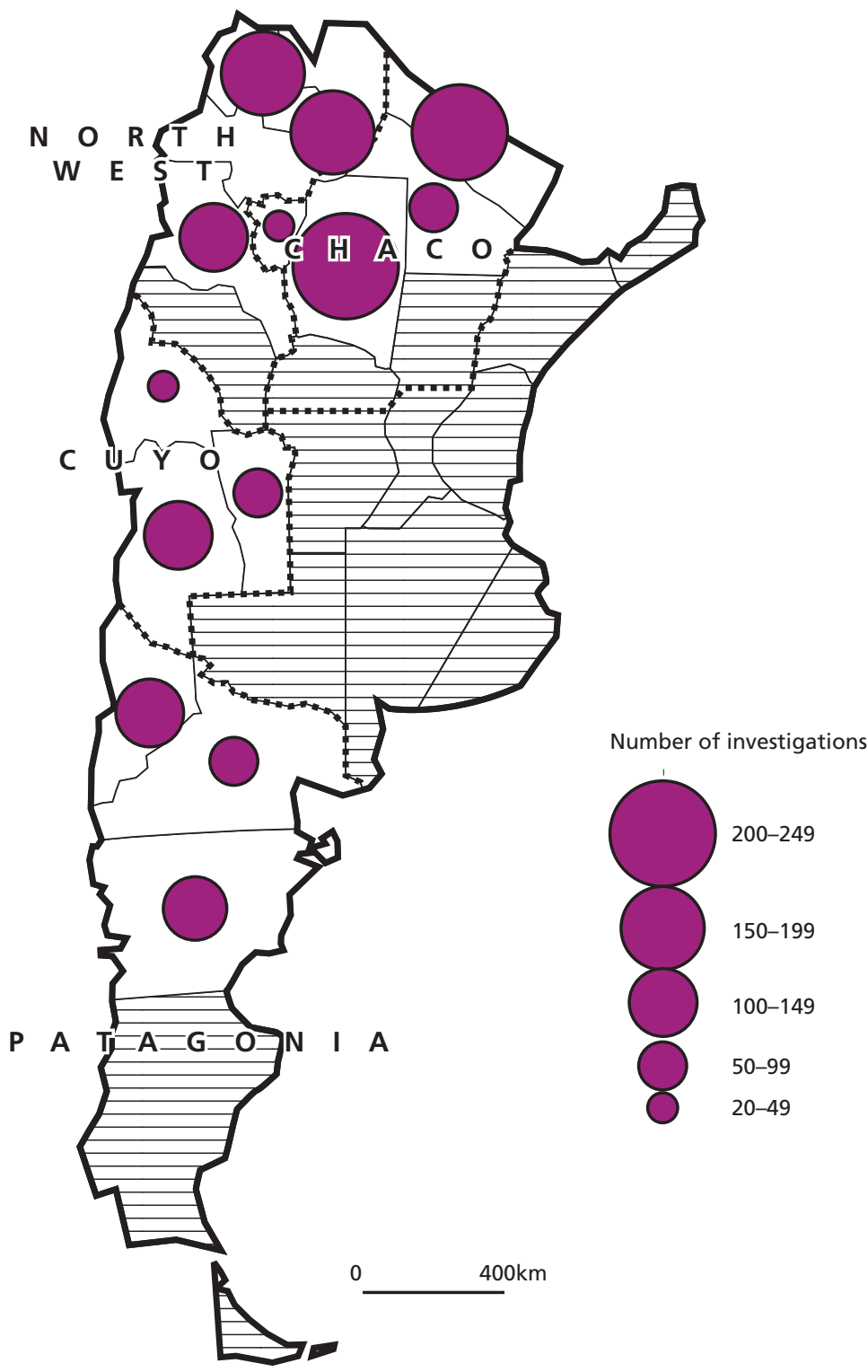

Source: Authors, based on Survey PKHICIRAD, 2019

Map conforms to Map No. 4170 Rev. 18.1 UNITED NATIONS, February 2020 
TABLE 3

Animal species' equivalent of the average LSU of 65

\begin{tabular}{ccccccc}
\hline Male Cattle & Female cattle & Male camel & Female camel & Adult male sheep & Female sheep & Male goat \\
\hline 11 & 19 & 6 & 8 & 11 & 24 & 17 \\
\hline Female goat & Male donkey & Female donkey & Horse & Mare & Pork & Female pig \\
\hline 120 & 6 & 5 & 6 & 6 & 6 & 7 \\
\hline
\end{tabular}

FIGURE 6

LSU distribution by region

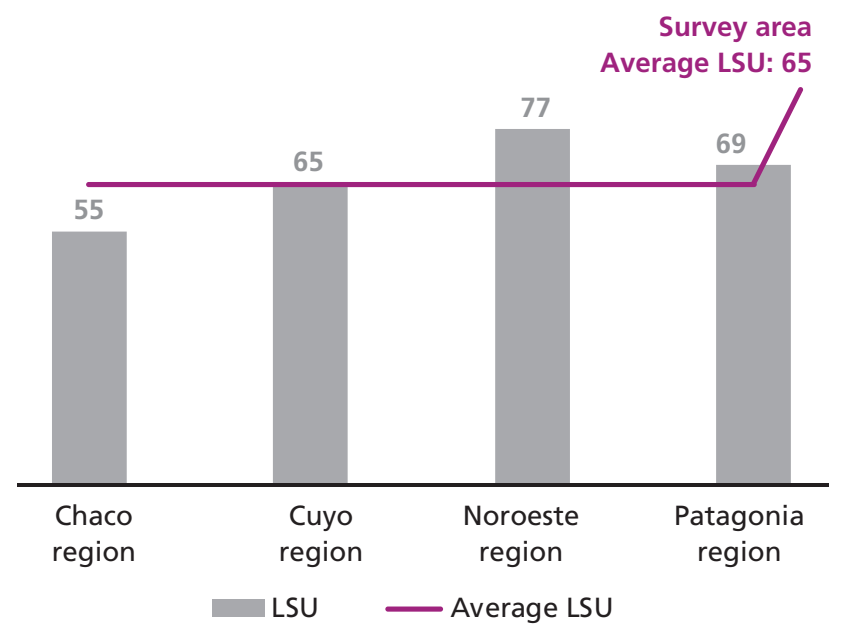

Source: Authors.

\section{PASTORALISM: REARING DIVERSE ANIMAL SPECIES}

The drylands of Argentina are home to cattle, small ruminants, horses and South American camelids. To aggregate various species and age as per convention, our estimates are based on the LSU.

This is a convenient way to use specific coefficients established initially on the basis of the nutritional or feed requirement of each type of animal.

Applied to Argentina, a pastoral household has on average 65 LSU, meaning that the pastoral household holds on average 30 cattle, 14 camelids, 35 sheep, 137 goats, 11 donkeys, 12 horses and 13 pigs (Table 3).

Pastoral households in Patagonia and Noroeste regions are better off on average (77 and 69 LSU respectively), while those in the Chaco region have smaller herd sizes (55 LSU) (Figure 6). 
Extensive livestock rearing is characterized by low investment in infrastructure and little use of technology and innovation.

Continuous grazing predominates, using mainly European and zebu breeds and their crosses. Most of the animals are produced for subsistence with family labor who handle the majority of livestock activities. Meat production is the primarily output; however, sheep wool, goat hair and cashmere breeds are increasingly important within pastoral and agropastoral families.

With the exception of the equidae and suidae families, there is a marked tendency for females to dominate herds, with the exception of the Rio Negro province, where male cattle seem to predominate. This could indicate a peculiar strategy of animal possession and also of marketing live animals.

\section{PASTORALISM AND REVENUE GENERATION}

Pastoralism cannot be measured only in monetary terms because, as mentioned in the conceptual framework, it has significant non-market returns. However, generating cash income remains important for households, often to cover expenditures.

In Argentina, the annual average gross revenue in pastoral and agropastoral areas is ARS 577927 (Figure 7). The Noroeste and Cuyo regions report the highest average revenue (ARS 846877 and ARS 596995 respectively) while the pastoral and agropastoral households in the Chaco and Patagonia regions report the lowest levels. This may be linked to the high average animal possession (77 and 65 LSU respectively) in higher-revenue regions.

FIGURE 7

Distribution of average gross revenue by province/region (Argentine Peso)

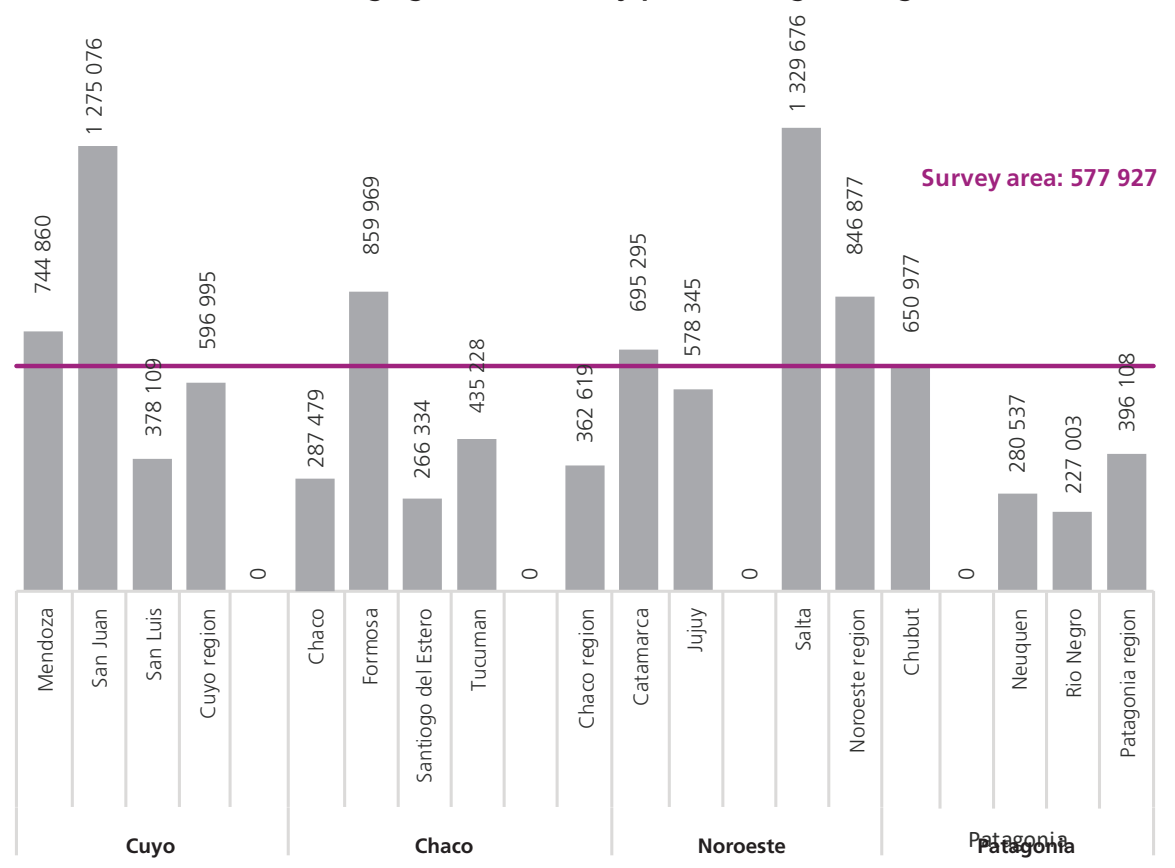

Source: Authors. 


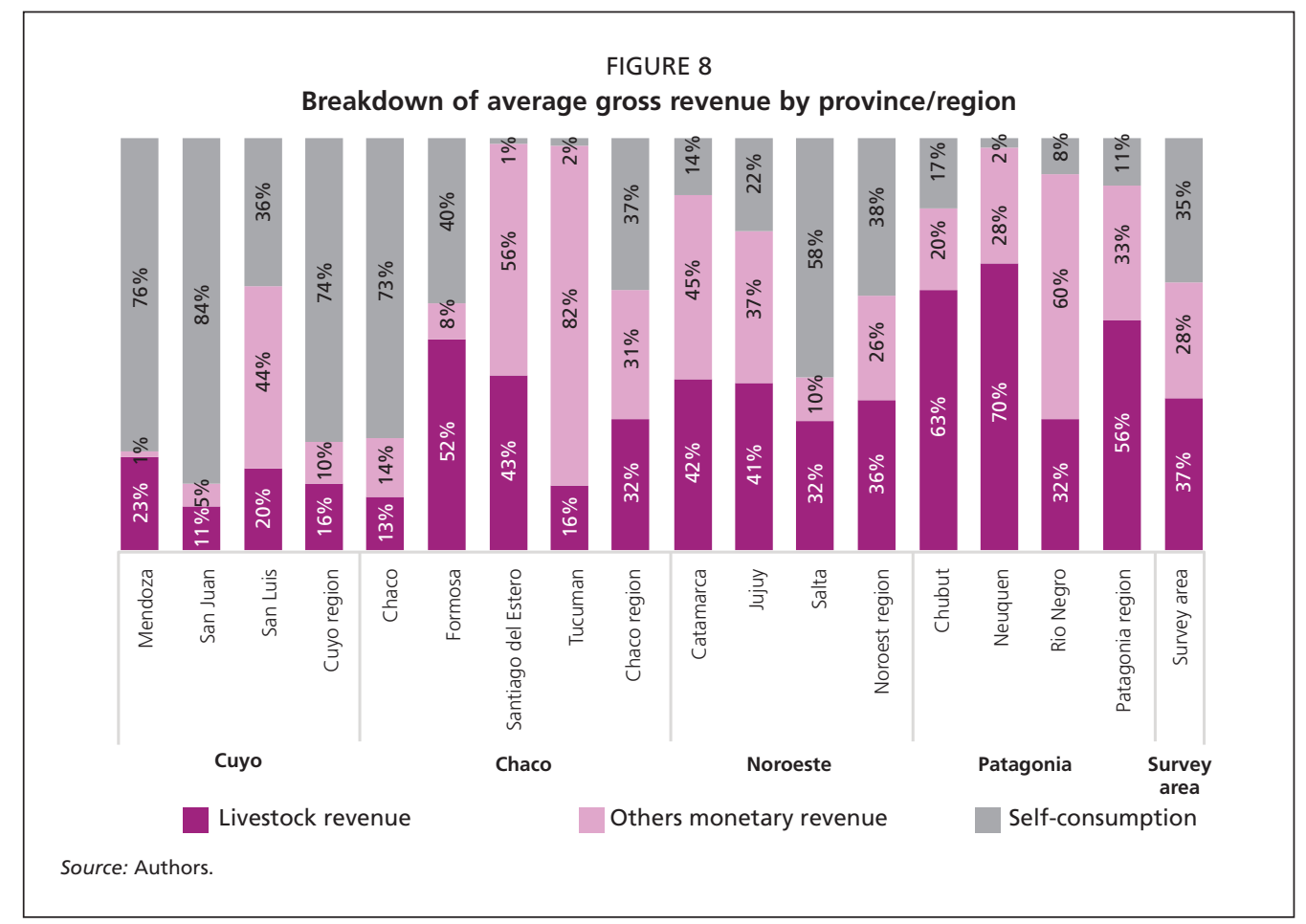

A more refined analysis (Figure 8 ) shows the importance of self-consumption as a source of revenue. Overall, the average gross revenue is provided by livestock product sales (37\%), other monetary revenue including off-farm revenue (28\%), and household self-consumption (35\%).

The breakdown of the gross revenue reveals strong regional disparities in revenue sources. Livestock revenues remain the main source only in Patagonia (56\%); it is less important than others in Cuyo, Chaco and Noroeste (16\%,32\% and 36\% respectively). The self-consumption component represents just over a third of revenues (37-38\%) in the Chaco and Noroeste regions. The Cuyo region is characterized by an extensive use of production for self-consumption (73\%) while households in Patagonia have weak recourse to self-consumption (11\%).

Regarding livestock product revenue (Figure 9), with the exception of the Cuyo region, where live animal sales are dominant, cash is mostly provided by animal fibre sales, in particular in Noroeste and Patagonia (almost 77\%).

It is noteworthy that crop sales are relatively marginal, as off-farm revenue (jobs, casual employment and subsidies) constitutes $80 \%$ of other sources of monetary revenue (Figure 10).

The categorization of households (Table 4) was elaborated from the revenue deciles classification that provides a rough ranking of their economic situation. This categorization thus resulted in a distinction between the low-revenue group, constituted by households earning no more than ARS 169400 per year; the lower-middle revenue group, which earns a maximum of ARS 310 800; the upper-middle revenue group, which can reach an average gross revenue of ARS 620 000; and the high-revenue group, which can generate more than ARS 620000 of annual gross revenue. 
FIGURE 9

Breakdown of average livestock revenue by province/region

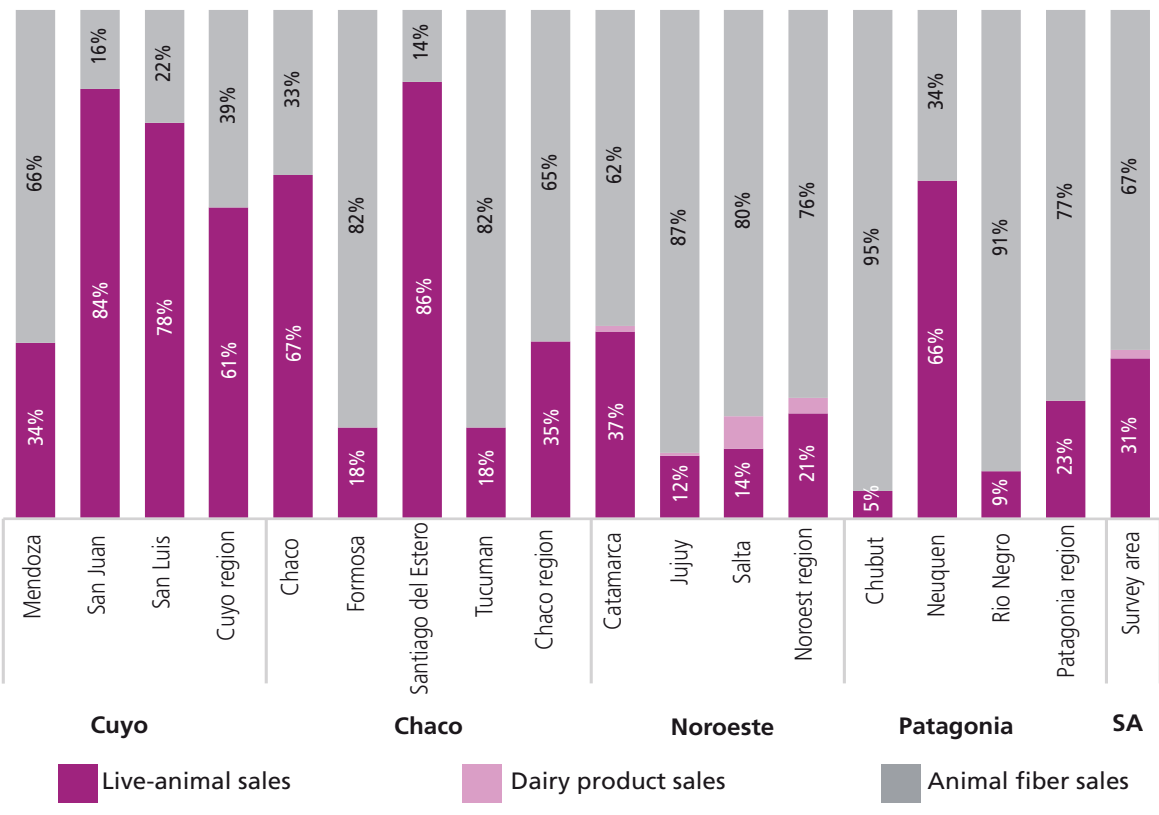

FIGURE 10

Breakdown of other sources of monetary revenue by province/region

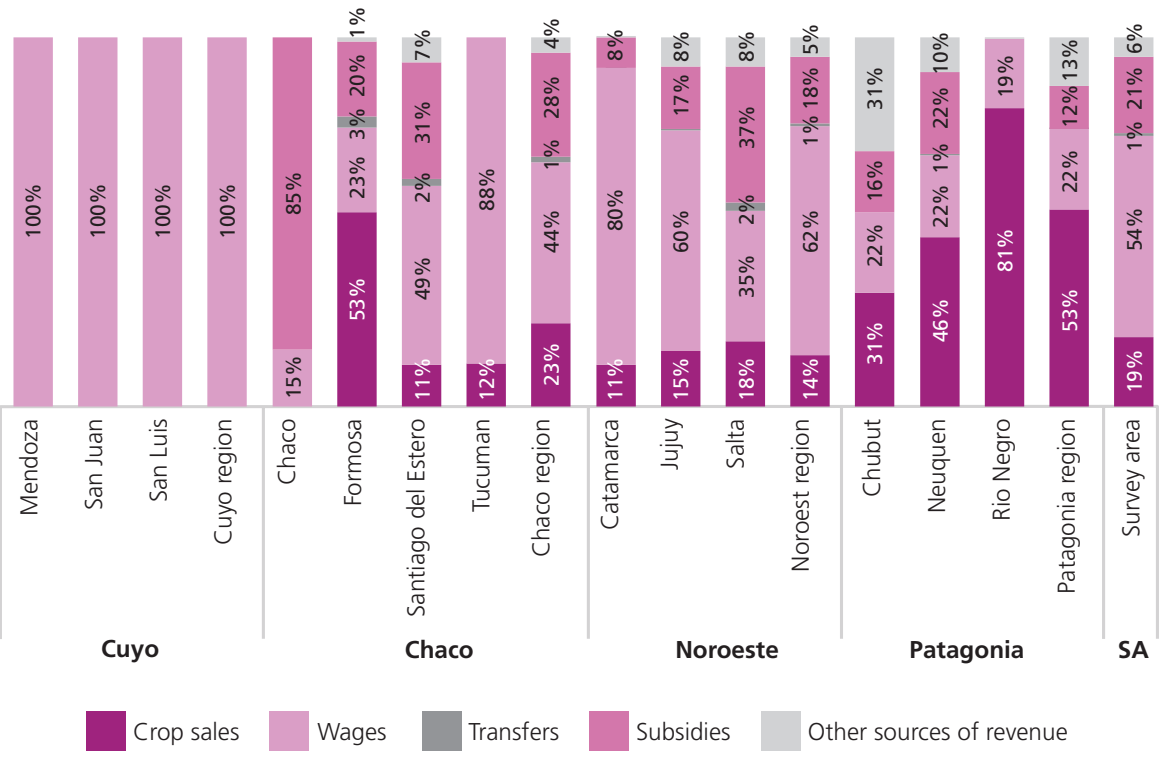


TABLE 4

\section{Categories of pastoral households according to their average gross revenue}

\begin{tabular}{|c|c|c|c|c|}
\hline \multirow{2}{*}{$\begin{array}{l}\text { Category name } \\
\text { Range }\end{array}$} & \multicolumn{2}{|c|}{ Low-revenue } & \multicolumn{2}{|c|}{ Lower-middle revenue } \\
\hline & Minimum & Maximum & Minimum & Maximum \\
\hline Revenue (ARS) & 0 & 169400 & 169401 & 310800 \\
\hline Category name & \multicolumn{2}{|c|}{ Upper-middle revenue } & \multicolumn{2}{|c|}{ High-revenue } \\
\hline Range & Minimum & Maximum & Minimum & Maximum \\
\hline Revenue (ARS) & 310801 & 620000 & 620001 & up to 620001 \\
\hline
\end{tabular}

FIGURE 11

Breakdown of the average gross revenue by category of household

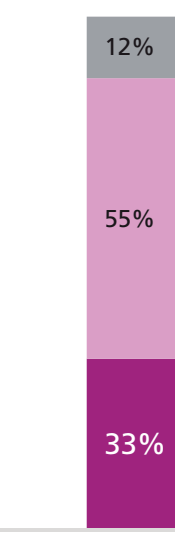

Low revenue

Livestock revenue

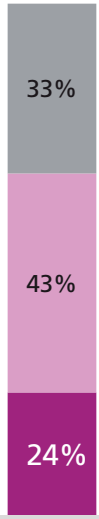

Lower-middle revenue

Other monetary revenue
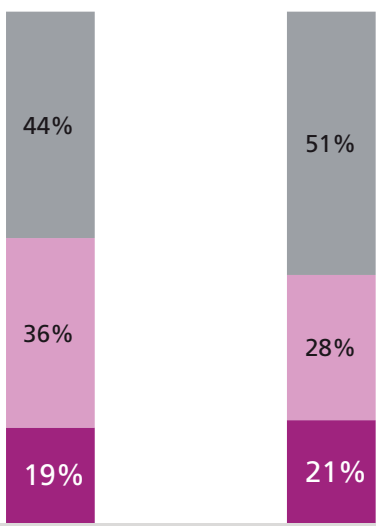

High revenue

Self-consumption

Source: Authors.

The analysis by category of household produces fairly instructive and informative findings. It shows a declining contribution of livestock product sales (from 33\% to $21 \%$ ) and other sources of monetary revenue (from $55 \%$ to $28 \%$ ), but an increasing contribution of self-consumption (12\% to $51 \%$ ) moving up the gross income ladder (Figure 11). This illustrates that the low-revenue group, and to a lesser extent the lower-middle revenue group, depend on other monetary revenue.

The importance of self-consumption must also be put into the perspective of the economic context of Argentina, which over the last five years has been facing galloping inflation. This hit $53.8 \%$ in 2019 , climbing to its highest level in almost three decades and underlining the scale of the country's challenges. In this context, the purchasing power of the population has been halved. Dramatic falls in monetary incomes in real terms were also experienced, leading to sharp increases in own-account production of crops and livestock in order to survive. The use of self-consumption helps to protect against market volatility. 


\section{PASTORALISM AND DIRECT PRODUCTION COSTS}

Our intention to compare our figures with standard measures of wealth leads to an analysis of direct production costs as a proxy of the intermediate costs incurred by households for animal purchases, animal health, animal watering, feed and services. The services include charges related to the use of shepherds, market intermediaries, conveyors, veterinary services, and animal traction.

On average, the direct and intermediate costs of the households reaches ARS 52682 per year. The Patagonia and Noreste regions report the highest cost levels (ARS 144721 and ARS 60861 respectively) while the Cuyo and Chaco regions report relatively lower cost levels (ARS 20032 and ARS 22121 respectively) (Figure 12). The prominent costs are feed purchases (65\%) and service charges (18\%). However, feed costs are proportionnally higher in the Patagonia and Noroeste regions and to a lesser extent in Chaco region (Figure 13).

\section{PASTORALISM AND WEALTH CREATION}

In scenario 1, representing the base-case model, pastoral and agropastoral households contribute $0.6 \%$ of the GDP. In scenario 2 , incorporating self-consumption as an important component of the gross revenue, the same households contribute $1.4 \%$ of the GDP. In scenario 3, that realistically takes into consideration the possession time horizon of the animals sold, pastoral and agropastoral households have a decreasing contribution to GDP proportional to the length of animal possession in the herd. The contribution of

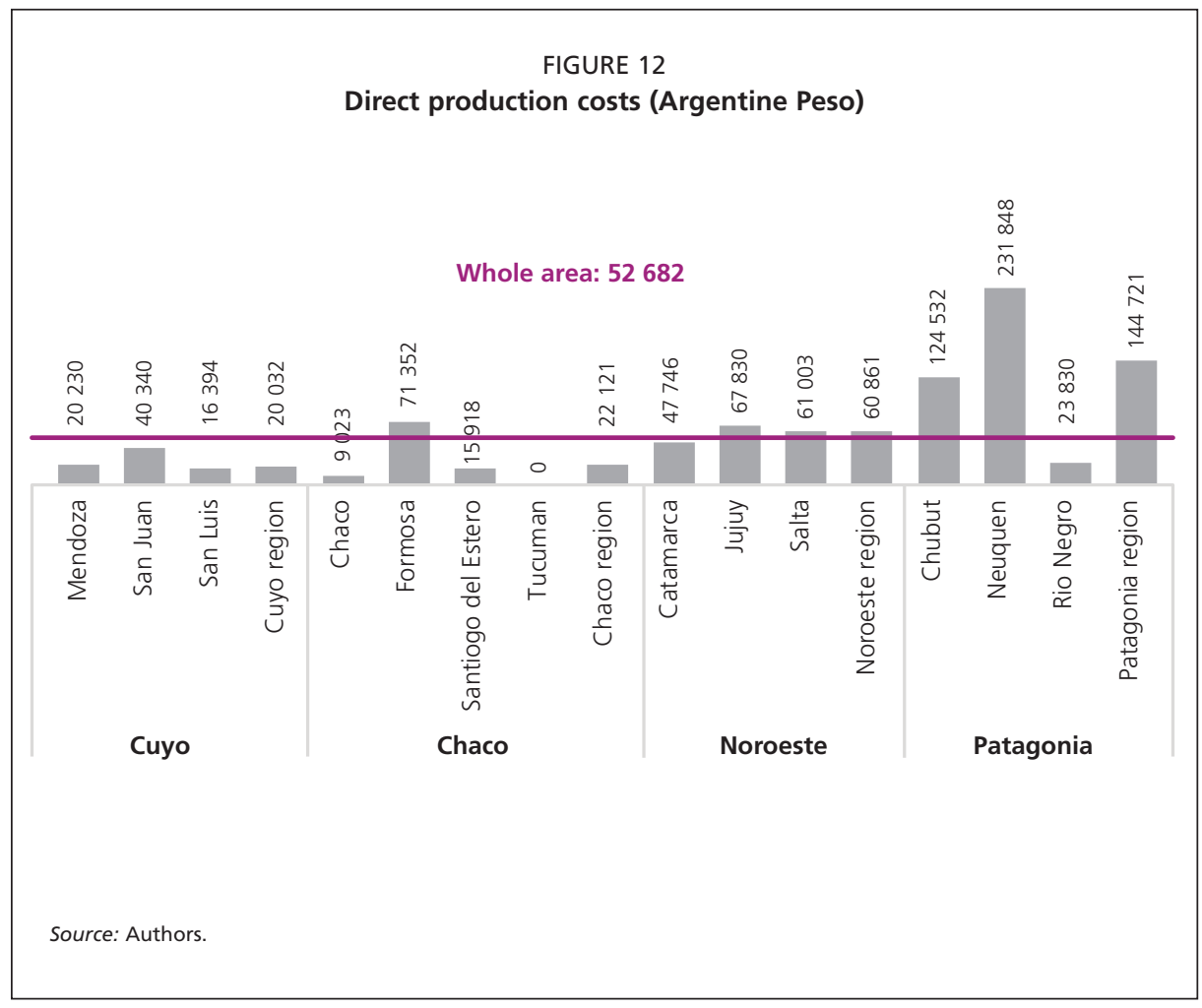




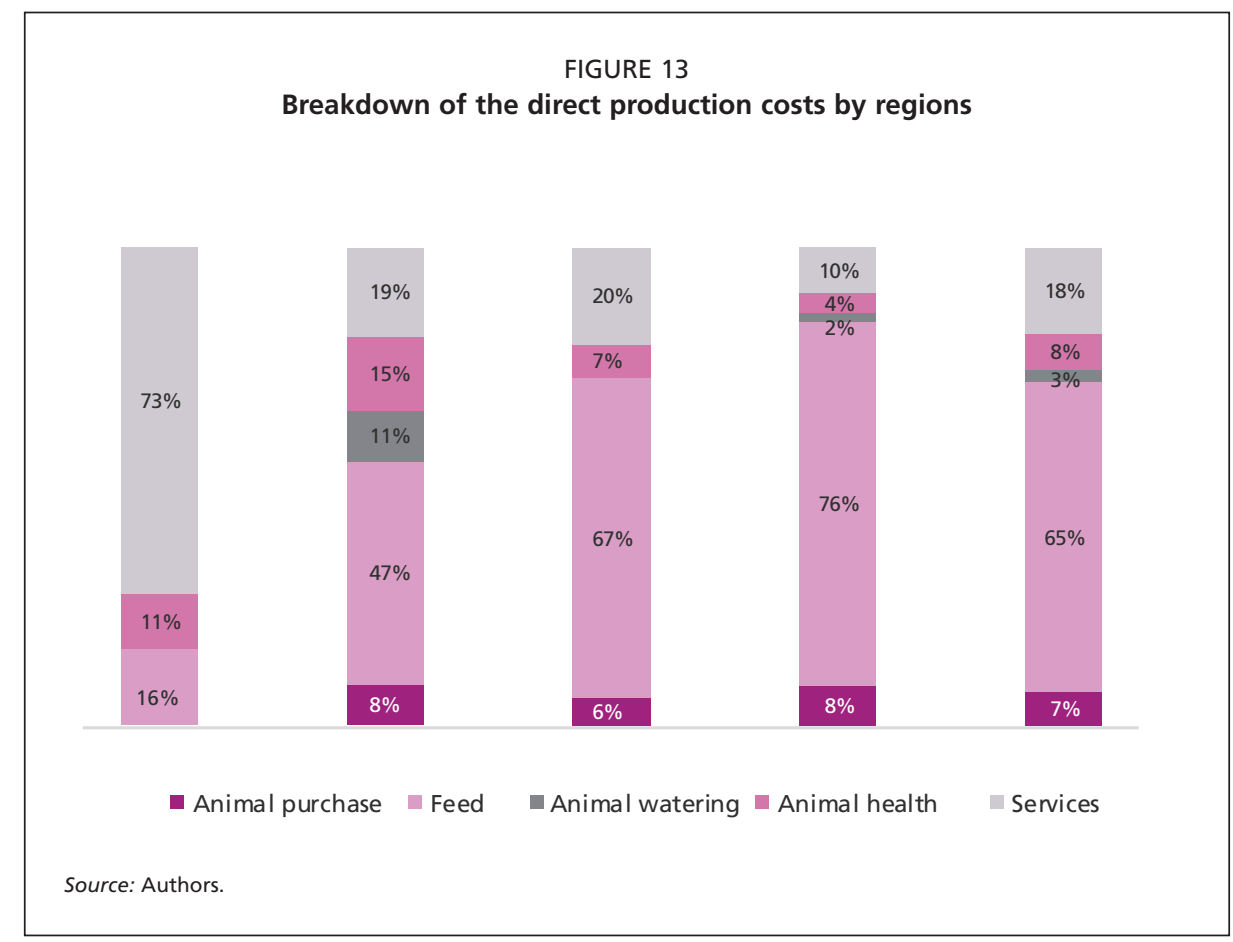

pastoralists to GDP thus declines to $0.3 \%$ (without self-consumption) and $1.2 \%$ (with self-consumption) assuming an average holding period of animals sold of two years. This contribution drops when the average ownership of animals sold is three years to reach $0.1 \%$ (without self-consumption) and 1.0\% (with self-consumption) (Figure 14).

\section{PASTORALISM AND REVENUE DISTRIBUTION}

Revenue and its distribution have always been a central concern of development researchers and practitioners as well as policymakers. This concern is all the more important as the distribution of revenue can be used to analyze potential sources of instability in pastoral areas. Revenue distribution is how a nation's total GDP is distributed among its population. To a larger extent, it is possible to explore how the gross revenue generated in pastoral and agropastoral areas is distributed among households. The distribution of revenue within a society may be represented by the Lorenz curve closely associated with measures of revenue inequality such as the Gini index, an accurate index for measuring revenue distribution that can vary from 0 (perfect equality, represented as $0 \%$ ) to 1 (perfect inequality, represented as 100\%).

It can be seen that on the basis of gross revenue, the distribution of revenue is very unequal (Gini index: 56.6\%) (Figure 15). These levels of inequality in Argentinean pastoral environments are similar to those found in in East Africa (Little et al., 2001) and West Africa (Wane et al., 2009). In Argentinean pastoral and agropastoral areas, the unequal distribution of the gross revenue is explained most by the unequal distribution of livestock revenue that includes live animal sales and fiber sales. Integrating self-consumption reveals its impact on overall inequality as the Gini index drops from 0.635 (distribution of livestock revenue) 


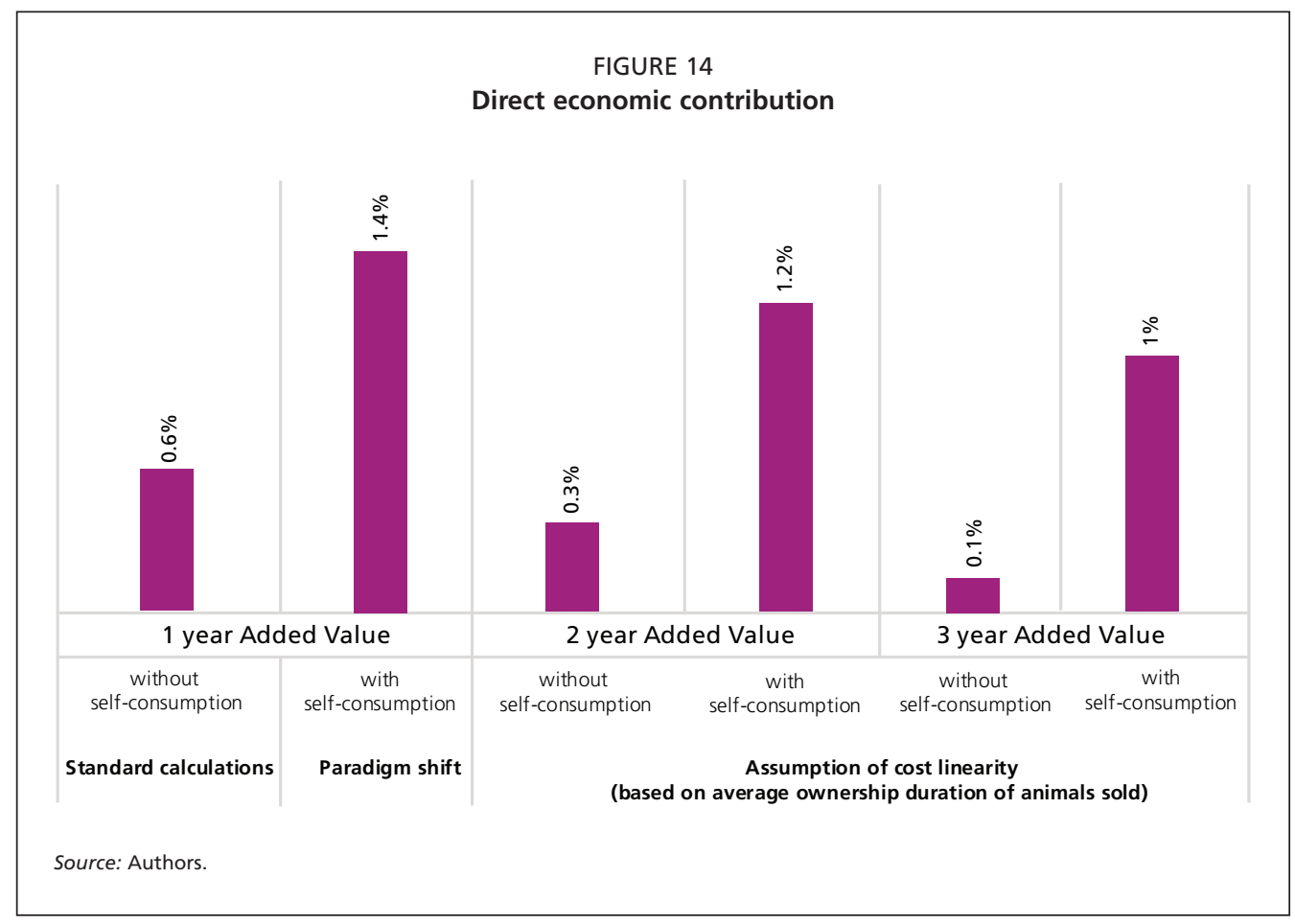

FIGURE 15

Evolution of the Gini index in Argentina

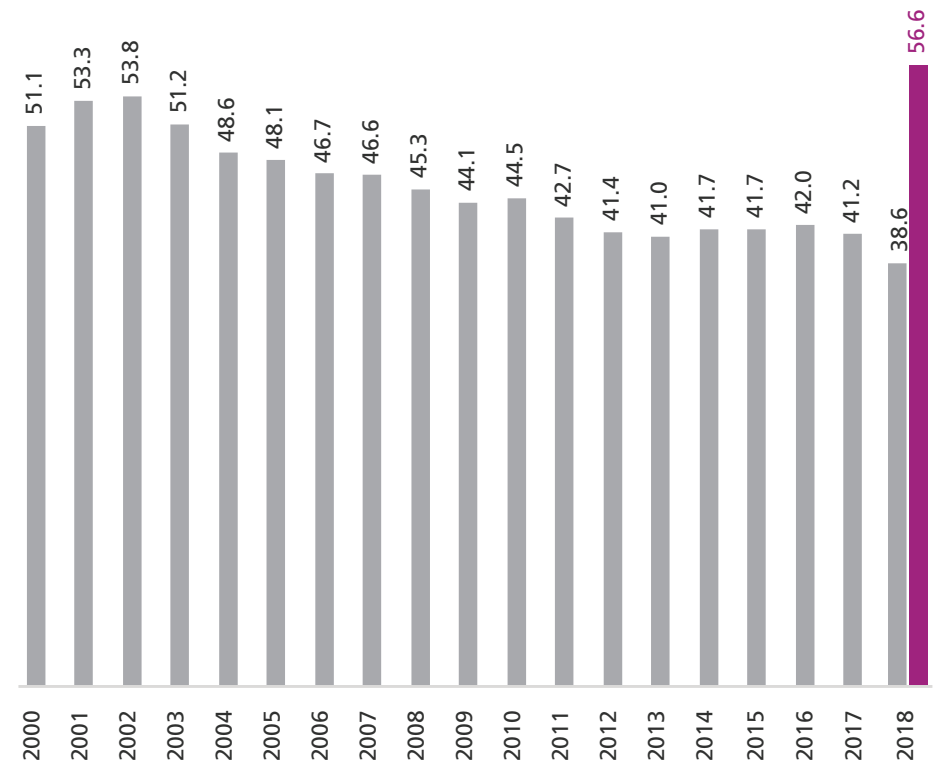


FIGURE 16

Lorenz curve and Gini index by revenue source

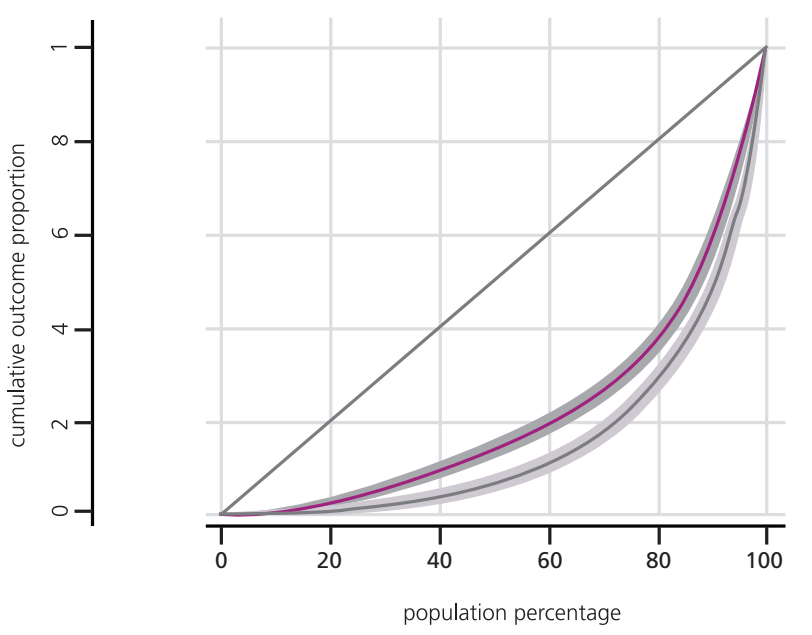

Livestock revenue $(0.635)$

Gross revenue $(0.566)$

Source: Authors.

to 0.566 (distribution of gross revenue) (Figure 16). This situation is all the more worrying since important efforts have been made by the Argentinean government to reduce economic inequality in Argentina, and the Gini coefficients dropped from 0.511 in 2000 to 0.386 in 2018. Indeed, Argentinian public authorities tried to implement an enabling environment to reduce income inequality (improvement of working conditions, both rate of employment and the quality of jobs; incorporation of people without formal labor income in the social security system with the increasing proportion of the population with access to retirement pensions and size of pensions).

\section{PASTORALISM AND MULTIFACETED PERCEIVED SHOCKS}

The adoption of effective ex ante mitigation strategies is a function of household and location characteristics. These include, among others, the decision makers' perceptions of risk that we tried to collect during our investigations.

The occurrence of climate shocks and extreme climatic events is widespread while some other shocks affect the household or community levels. Thus, it is possible to distinguish idiosyncratic shocks (i.e. household-level shocks) and covariate shocks (collective-level shocks).

Pastoral and agropastoral households report that most of the multifaceted shocks they are facing affect the whole pastoral sector (78\%) rather than the household level (22\%) (Figure 17). 
FIGURE 17

Occurrence of shocks by type

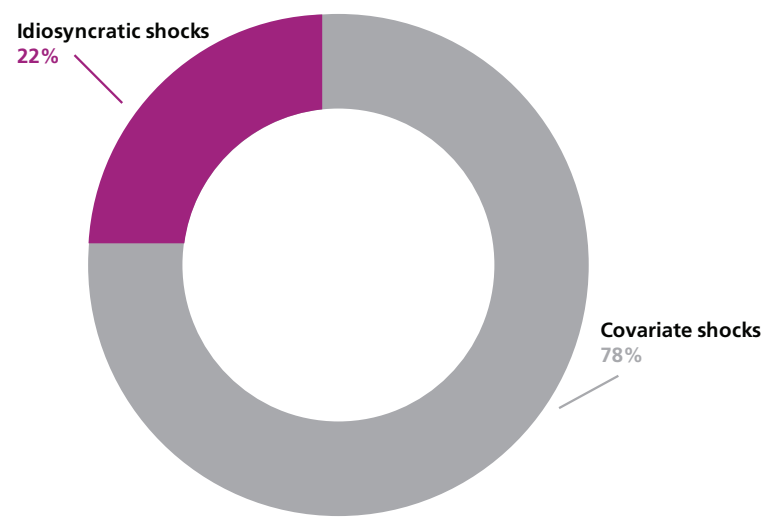

Source: Authors.

Overall, pastoral and agropastoral households in Argentina report a range of covariate risks (Figure 18). Natural-related as well as economic-related shocks emerge as the predominant risks that households have faced at least once during the last 15 years.

More specifically, the global figures in the whole area indicate that $35 \%$ of sample households reported having experienced rainfall issues. The second-most important shock is related to rising food prices, reported by $21 \%$ of sample households. The third-most important shock is a natural-related one and involves thermic stress (14\%).

Regarding the idiosyncratic shocks faced over the last 15 years, sample households mostly reported health-related shocks as the predominant one, then social and political-related events that affected their livelihoods. Thus, 35\% of sample households experienced animal losses due to diseases, $15 \%$ mentioned the death of an active family member as an important shock, and $14 \%$ stated that a lack of access to veterinary services and also cattle theft has negative impacted their production systems and livelihoods.

At the regional level, covariate trends are confirmed, although the perception of natural phenomena is stronger in $\mathrm{Chaco}$, where rainfall shortages and thermic stress were reported respectively by $39 \%$ and $19 \%$ of sample households (Figure 19A). In Noroeste and Patagonia (Figures 19C and 19D), rainfall issues also were mentioned frequently by sample households (36\% and 33\% respectively). They also often reported inflation problems ( $25 \%$ and $23 \%$ respectively). However, in Cuyo (Figure 19B), households provided more details by talking about natural-related shocks (thermic shocks, rainfall shortages, floods and untimely lightning strikes). With reference to idiosyncratic shocks, households in Noroeste and Patagonia have extensively reported multifaceted social and political-related shocks. 
FIGURE 18

Perceived shocks in the survey area

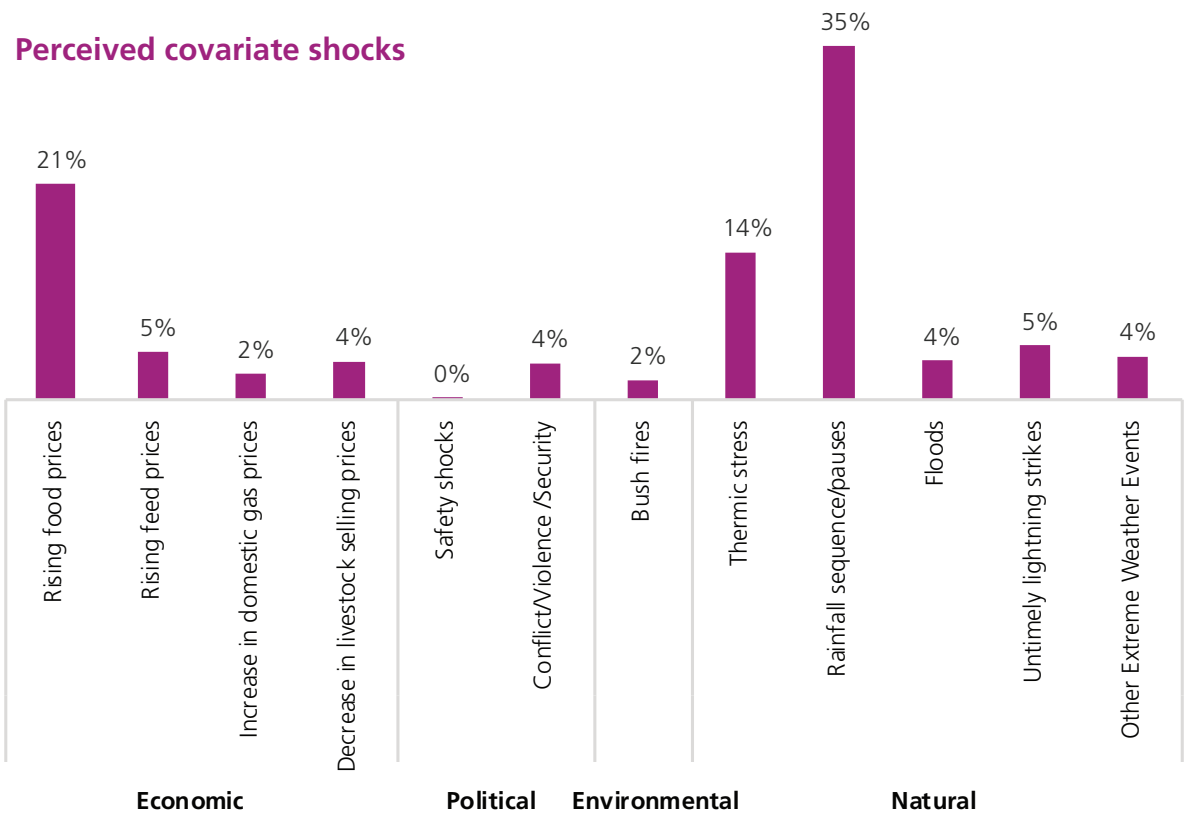

Perceived idiosyncratic shocks

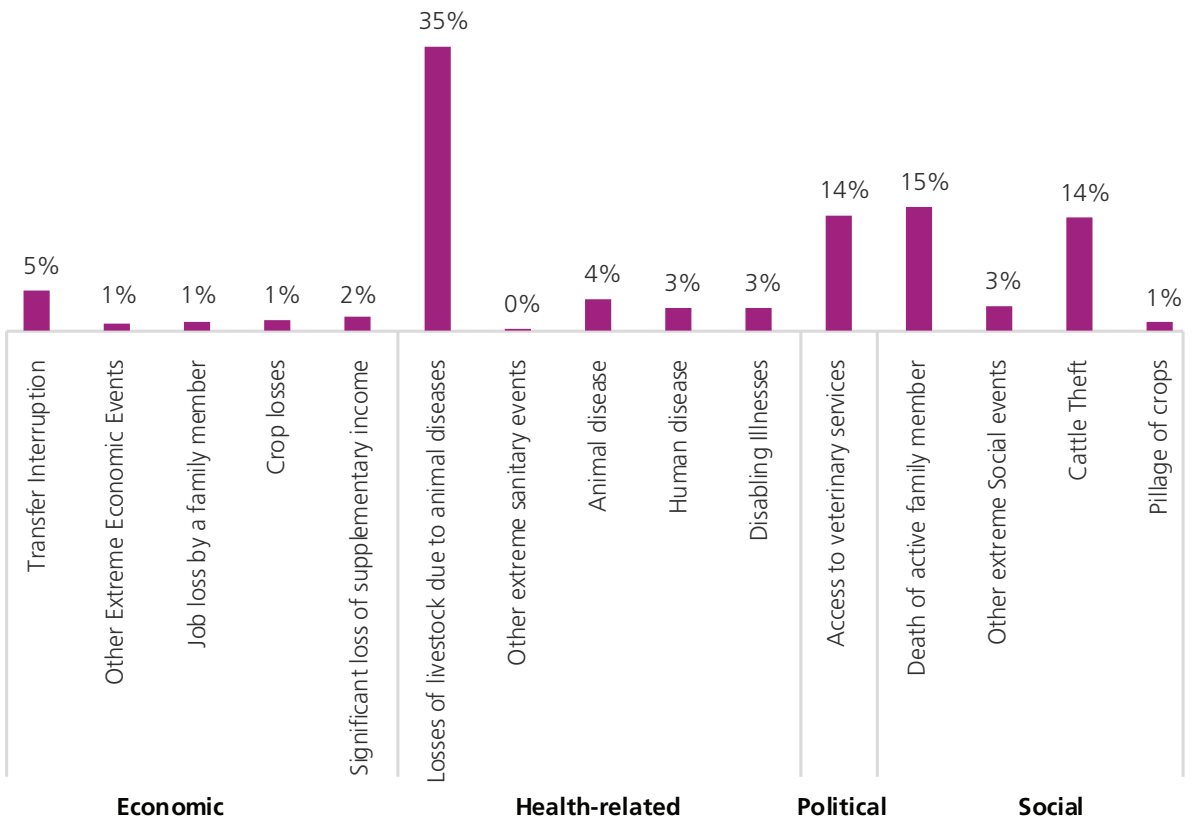

Source: Authors. 
FIGURE 19A

Multiscale perceived covariate and idiosyncratic shocks in Chaco

Covariate shocks

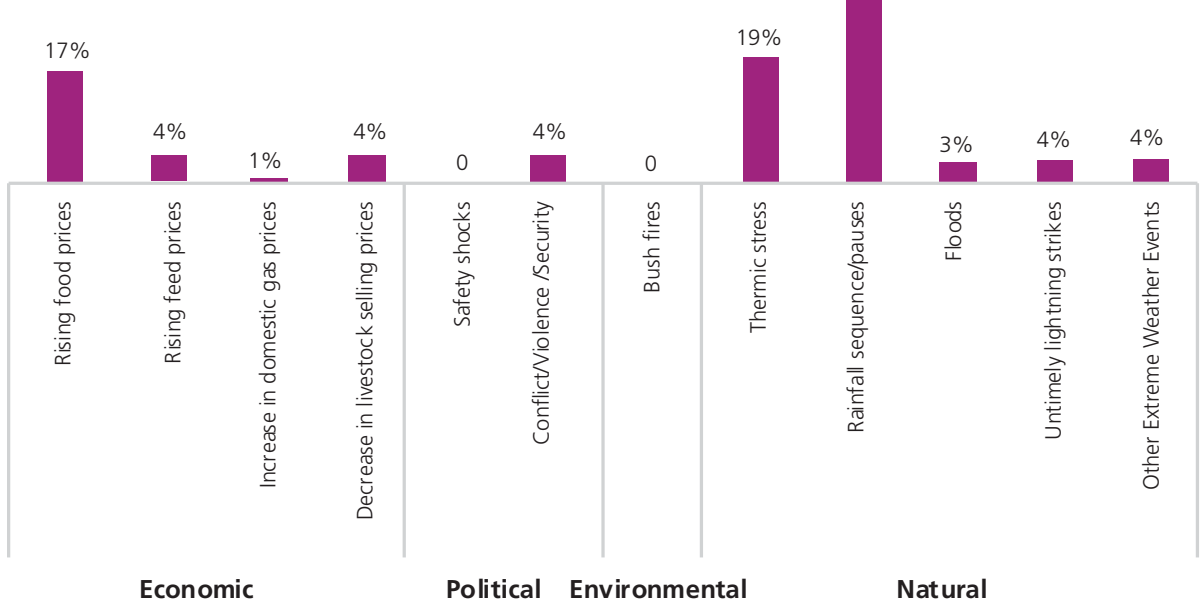

Idiosyncratic shocks

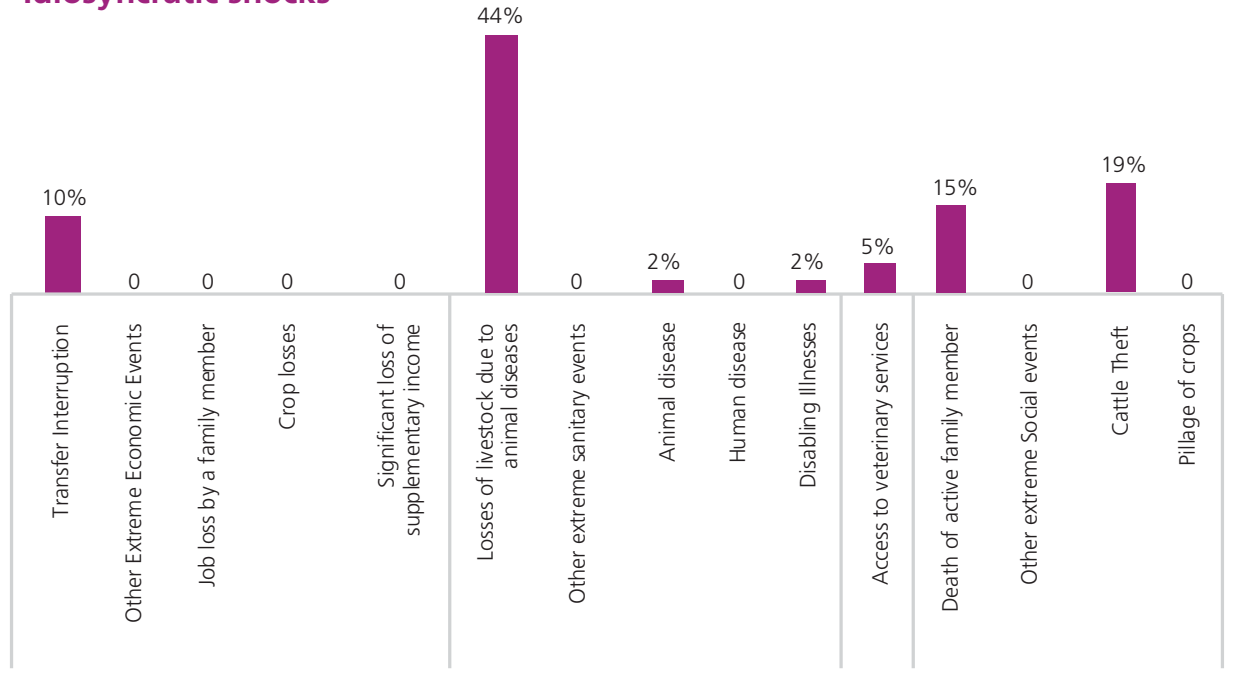


FIGURE 19B

Multiscale perceived covariate and idiosyncratic shocks in Cuyo

Covariate shocks

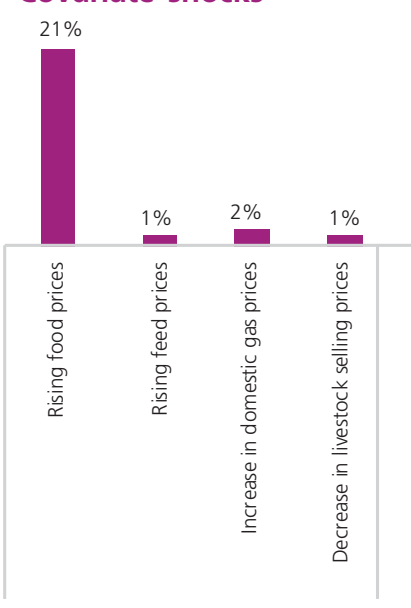

Economic

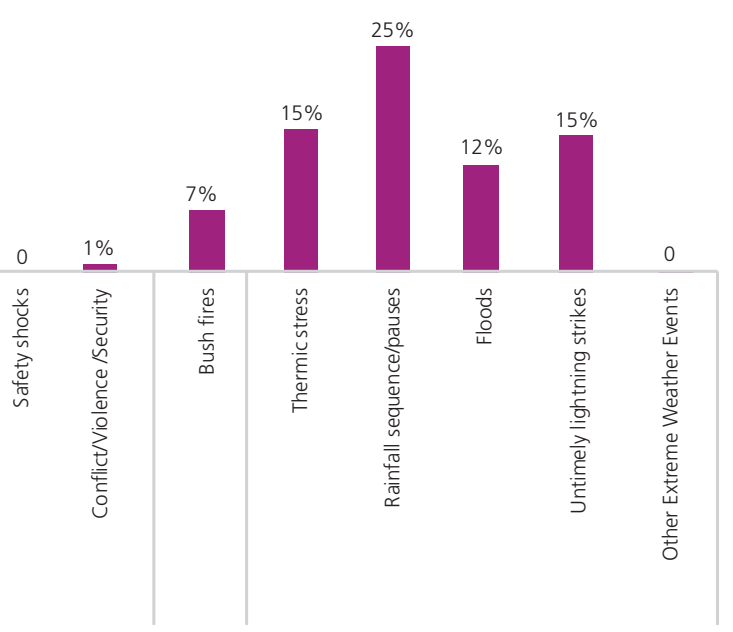

Political Environmental

Natural

Idiosyncratic shocks

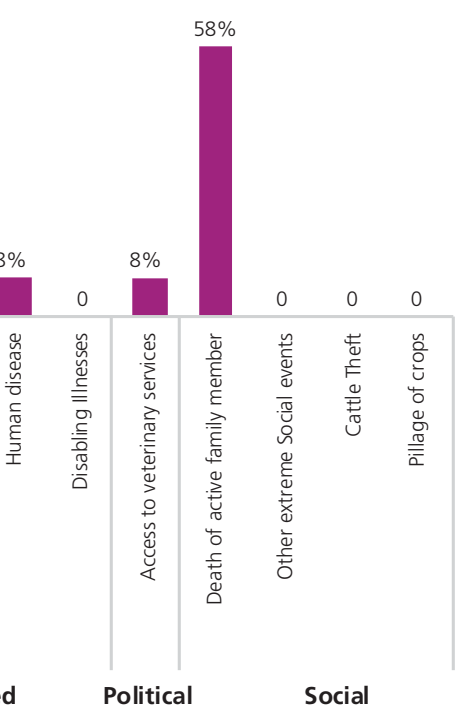

Source: Authors. 
FIGURE 19C

Multiscale perceived covariate and idiosyncratic shocks in Noroeste
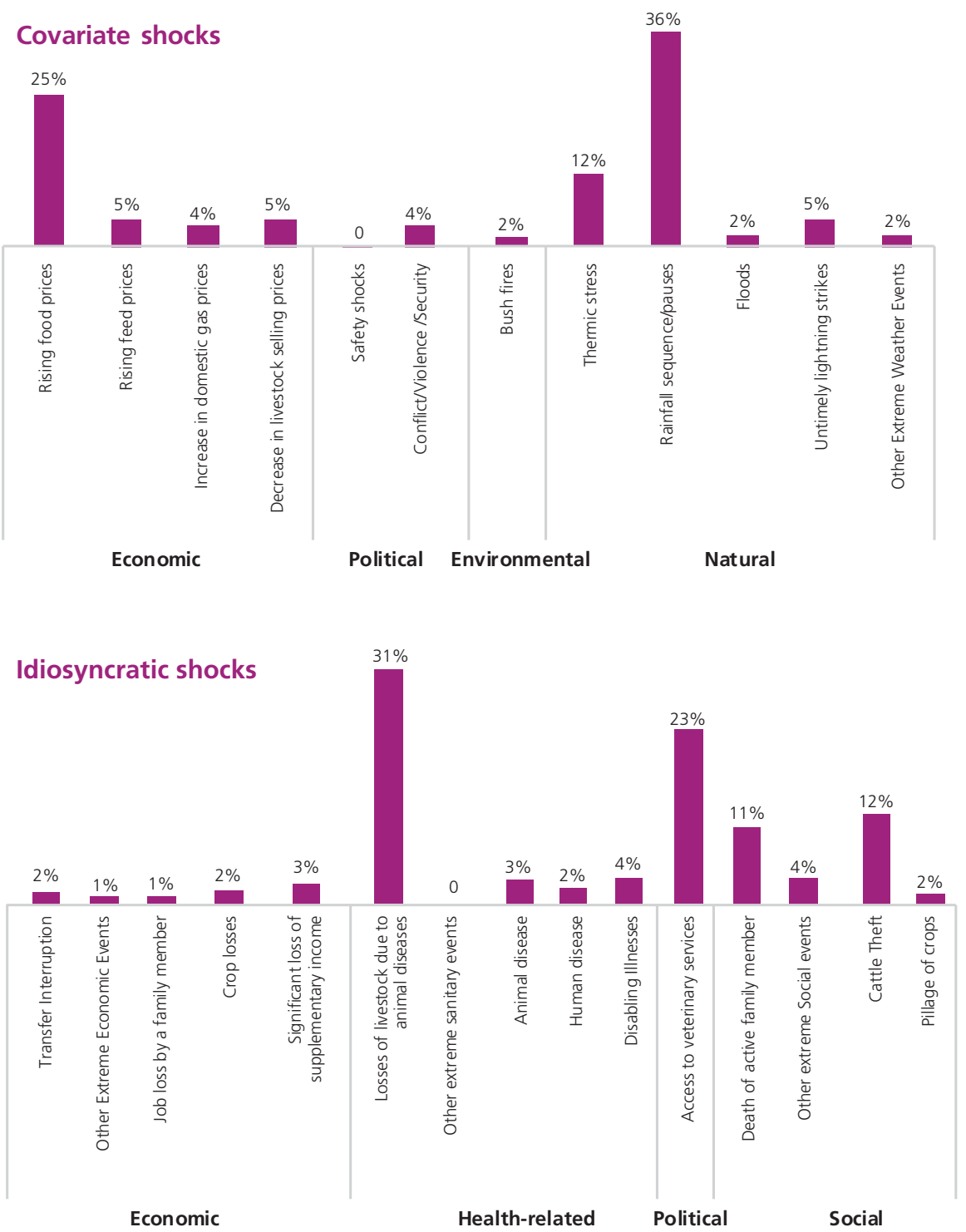
FIGURE 19D

Multiscale perceived covariate and idiosyncratic shocks in Patagonia

Covariate shocks

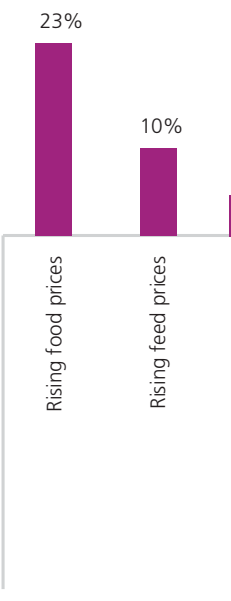

Economic

Political Environmental

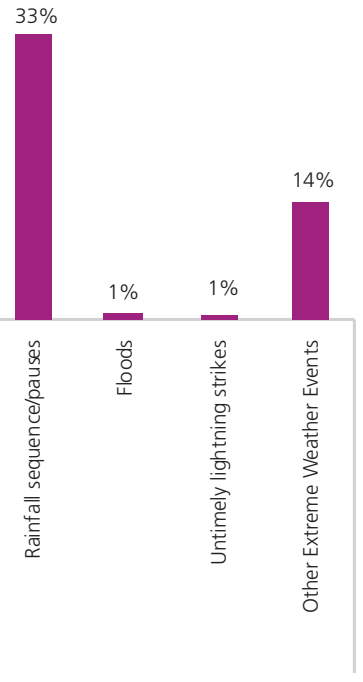

Natural

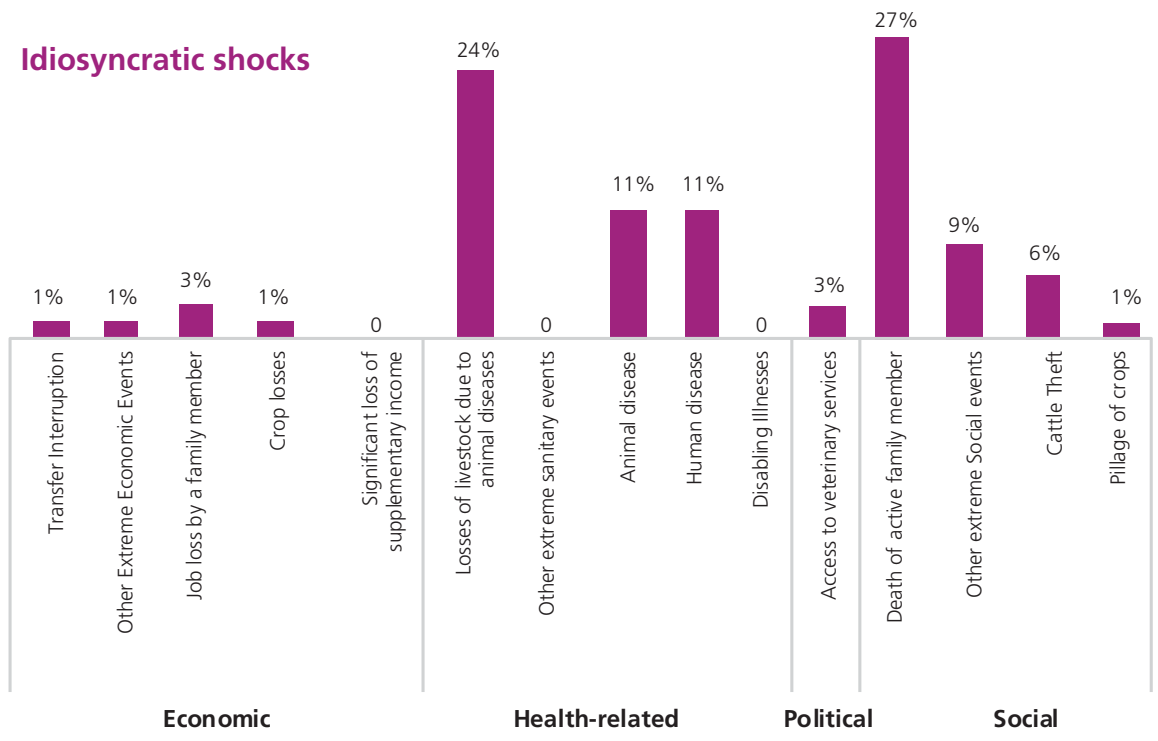

Source: Authors. 


\section{PASTORALISM AND CONTINGENCY STRATEGIES}

As a way of reducing the impact of multifaceted shocks, pastoral and agropastoral households in Argentina are adopting a range of options to preserve their production systems and livelihoods.

Although the data collection tools were structured around sequential and prioritized strategies, the household responses show that in some cases, strategies overlap. Indeed, the most important strategy revealed by the households is to strengthen their mobility by increasing the frequency and amplitude of movements to other areas. However, this strategy seems to be accompanied by recourse to family labor to complement cattle herding and accompany mobility. Use of family labor appears to be the second-most important strategy but one that is closely related to the mobility strategy.

In parallel to these two most important strategies, households use complementary strategies, such as other forms of pastoral adjustment (animal sales) and mobilizing social capital. The use of alternative strategies related to changing dietary habits and selling assets are more often cited as the third-most important strategy, one which can severely constrain their food security.

It should be noted that there is virtually no recourse to official aid applications, thus showing that pastoral and agropastoral households seek to mobilize endogenous strategies based on their own system of actions rather than relying on third parties in the form of grants, subsidies and credits.

These general trends are observable at the level of the total household sample and are similar to those visible at the regional level (Figure 20). 


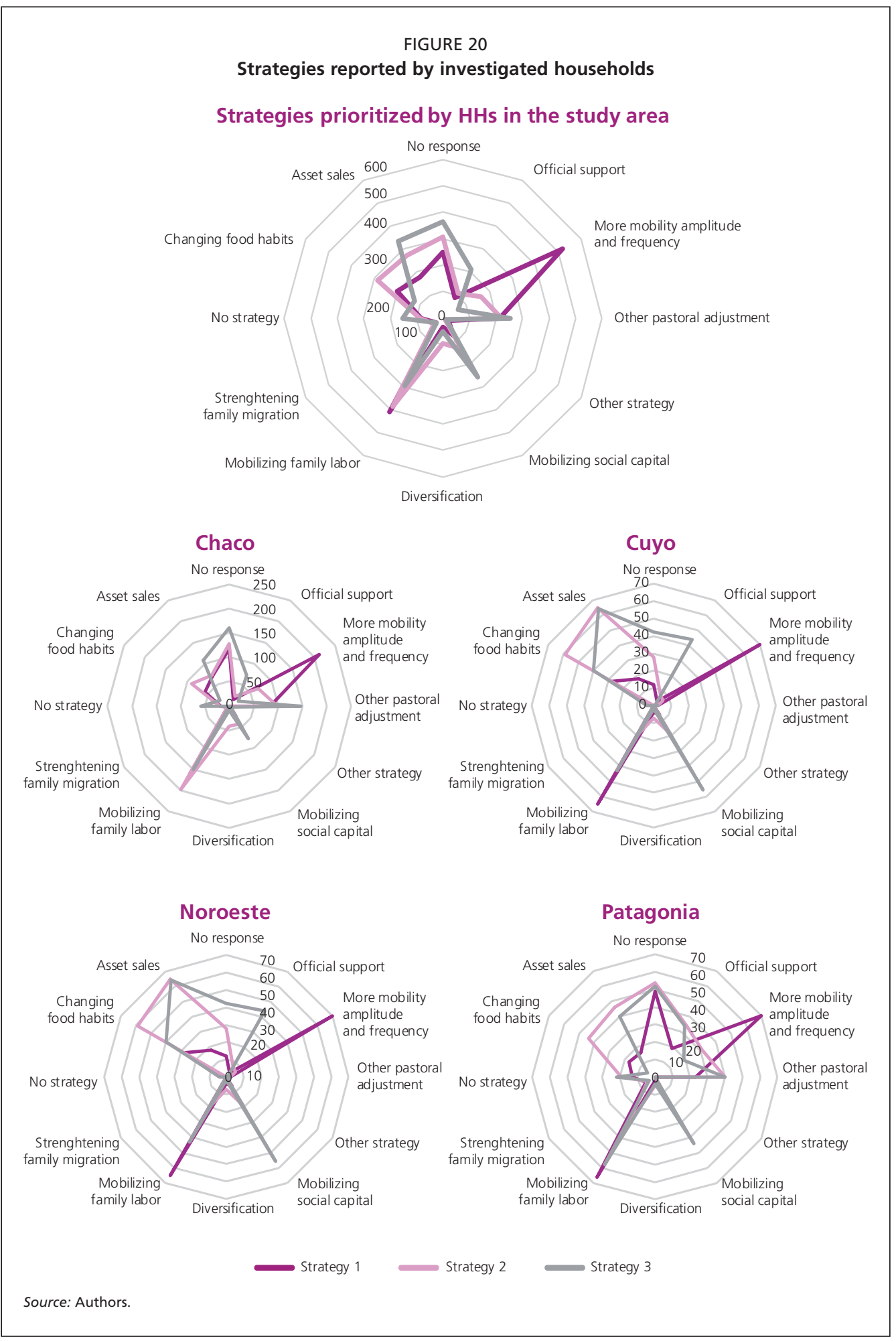





\section{Chad}

\section{BACKGROUND AND MACRO CONTEXT}

As an arid, low-revenue and landlocked Sahelian country in central Africa, Chad has been heavily dependent on oil since 2003. Although wealth creation has increased sharply, growing from USD 2.1 billion on average during the period 1961-2010 to USD 11.3 billion in 2018 (Figure 21), the country remains vulnerable to severe and multifaceted shocks. Climate, economic and social disturbances have deeply affected the newly oil-oriented country, and the oil sector is benefiting from important investments to the detriment of an increasingly neglected primary sector.

Weaker export performances, due to softening external demand and lower commodity prices, were responsible for larger external balances. There has been a slight recovery of the external current account deficit, which decreased from 6.6\% to $4.7 \%$ between 2018 and

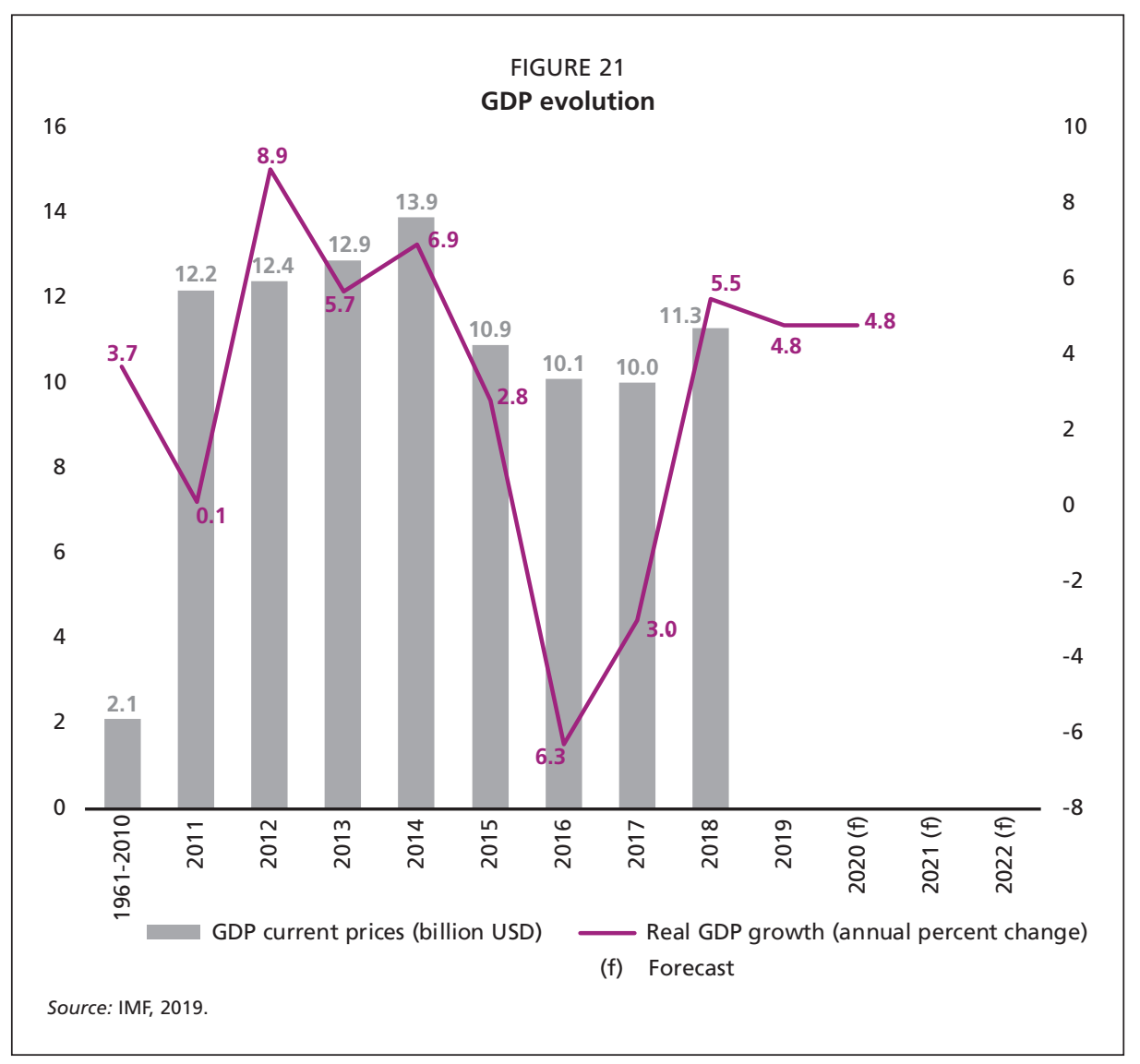




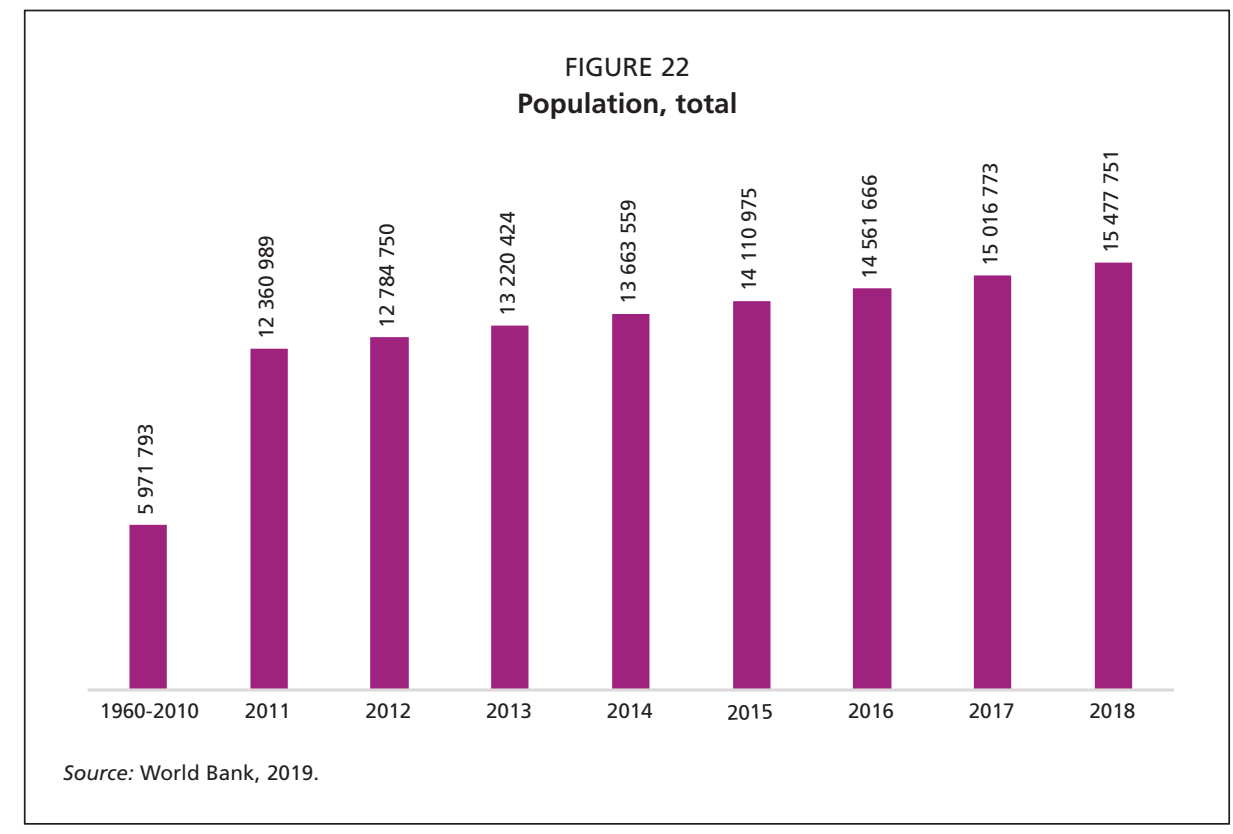

2019, but risks of debt overhang are high. Oil revenues have contributed to improved economic performances, but these were not sufficient to cover the social demand of a growing population (+25\% during the last decade according to the World Bank (2019)) (Figure 22).

Although efforts have been made in poverty reduction (from $55 \%$ to $47 \%$ between 2003 and 2011), poverty indicators still present a challenging picture as the number of poor people rose from 2011 to 2018. The country ranks within the bottom ten of the Global Hunger Index (118 of 119), the Fragile State Index (171 of 178) and the Gender Inequality Index (186 of 189). In addition to its internal challenges, Chad has faced the massive arrival of refugees from unstable and conflict-afflicted areas of Sudan, Central Africa Republic and Nigeria (WFP, 2019).

\section{DATA COLLECTION AND MANAGEMENT: INCLUSIVENESS OF PASTORAL ORGANIZATIONS}

One of the objectives of the PKH is to ensure a strong inclusion and involvement of pastoral organizations in the collection and management of data on the pastoral and agropastoral household economy in Chad. This approach is expected to contribute to the reliability of the collection process. A regional organization of Sahelian pastoralists and agropastoralists, the RBM and its Chadian partner, the COPAFIB, have fully fulfilled this function. With the technical and scientific support of CIRAD and FAO, these two organizations have been significantly involved in facilitating the identification and access to pastoral and agropastoral households for the implementation of primary data collection. This partnership was formalized around the census of households to be surveyed, and the recruitment and training of enumerators on data collection tools. The information was closely triangulated with data produced by the first census work realized by the team and those of the Bureau Central du Recensement Général de l'Elevage, the Chadian Livestock Census Bureau (BCRGE, 2012-2015). 
Distribution of sample investigated household at the provincial level in Chad

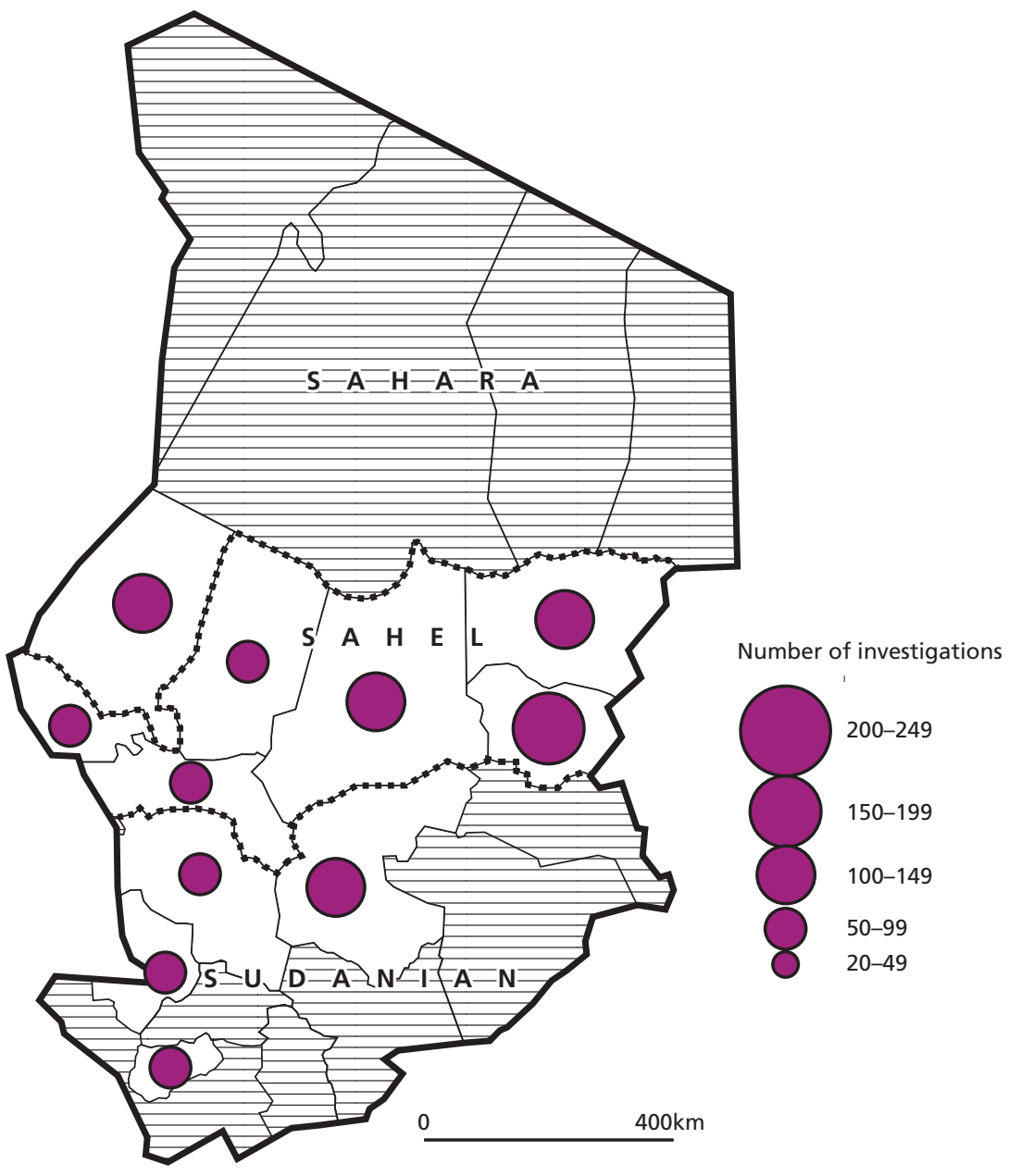

Source: Authors, based on Survey PKHICIRAD, 2019.

Map conforms to Map No. 4170 Rev. 18.1 UNITED NATIONS, February 2020.

Based on these representative data on pastoral livestock in Chad, questionnaires were developed to gather primary information on the revenue, expenditures, perception of shocks and strategies of the pastoral and agropastoral sample households in Chad.

The household economy survey covered the 2017/2018 agropastoral period. The choice of the sample was based on the different production systems and agroecological zones of Chad in order to be representative (Map 2). Finally, the usable sample consisted of 813 households.

Three agroecological zones were distinguished according to rainfall gradients: the Sudanian, Sahelian, and Saharan zones.

The Sahelian zone covers the provinces of Ouaddaï, Batha, Hadjer Lamis, Wadi Fira, Bahr El Ghazal, and the Lake, and represents the majority of households surveyed (58.4\%). 
TABLE 5

Animal species' equivalent of the average TLU of 192

\begin{tabular}{cccccc}
\hline Male cattle & Female cattle & Male camel & Female camel & Male sheep & Female sheep \\
\hline 24 & 78 & 11 & 25 & 29 & 43 \\
\hline Male goat & Female goat & Male donkey & Female donkey & Horse & Mare \\
\hline 13 & 31 & 5 & 4 & 4 & 3 \\
\hline
\end{tabular}

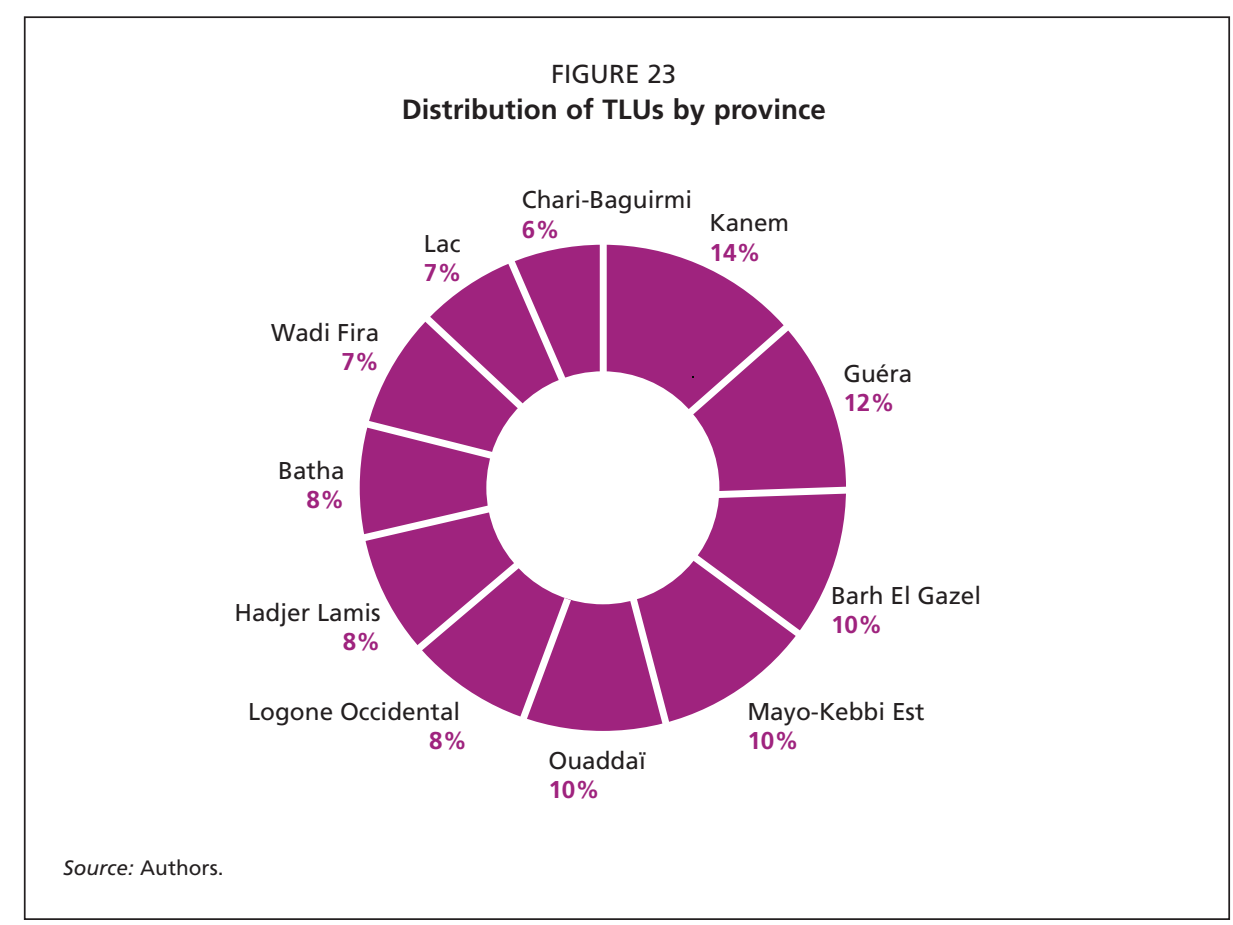

The Sudanian zone covers agropastoral provinces, such as Chari-Baguirmi, Logone Occidental, Mayo-Kebbi Est, and Guéra, and regroups 29.6\% of the households surveyed.

The Saharan zone is made up solely of the Kanem region, and has $11.9 \%$ of the households in the study area. We were unable to investigate in other provinces for security reasons.

The average animal possession of pastoral households is 192 TLUs, meaning that a pastoral household holds on average 102 cattle, 36 camels, 73 sheep, 45 goats, 9 donkeys, and 7 horses (Table 5).

The distribution of livestock in terms of TLUs shows that the provinces of Kanem (14\%), Guéra (12\%), Bahr El Ghazal (10\%), and Ouaddaï (10\%) concentrate the largest numbers (Figure 23). 


\section{PASTORALISM AND REVENUE GENERATION}

The average overall revenue per year per household is XAF 3030760 (Figure 24). There are significant disparities between agroecological zones. The Sudanian zone has the highest average overall revenue at XAF 5155 444, followed by the Sahelian zone (XAF 2660 617), and the Saharan zone with the Kanem region (XAF 1926 280).

The disaggregation of average gross revenue allows its main components to be distinguished. Sales of livestock products (live animals and dairy products) remain the main source of cash revenue (54\% of the gross revenue). Around $16 \%$ of cash revenue comes from agriculture, wage-labor, diversification activities and transfers from household members or affiliates working outside the pastoral activity zone and periodically sending money to support their families (Figure 25).

The structure of the revenue also highlights the importance of self-consumption, which contributes $30 \%$ of the average overall revenue. At the provincial level, there are some differences in the average importance of self-consumption. Households in Kanem province seem to be more inclined to use their production for self-consumption.

A more detailed livestock revenue analysis shows that pastoral and agropastoral households derive three-quarters of their revenue from the sale of live animals. Sales of dairy products represent $26 \%$ of livestock revenue. The share of dairy sales is higher in Hadjer Lamis, contributing $62 \%$ of livestock revenue. This can be explained by the proximity of the capital city, N'Djamena, which is an important outlet for dairy products. Similarly, $N^{\prime}$ Djamena offers more possibilities in terms of the presence of small dairy units and equipment for the collection, processing and conservation of dairy products.

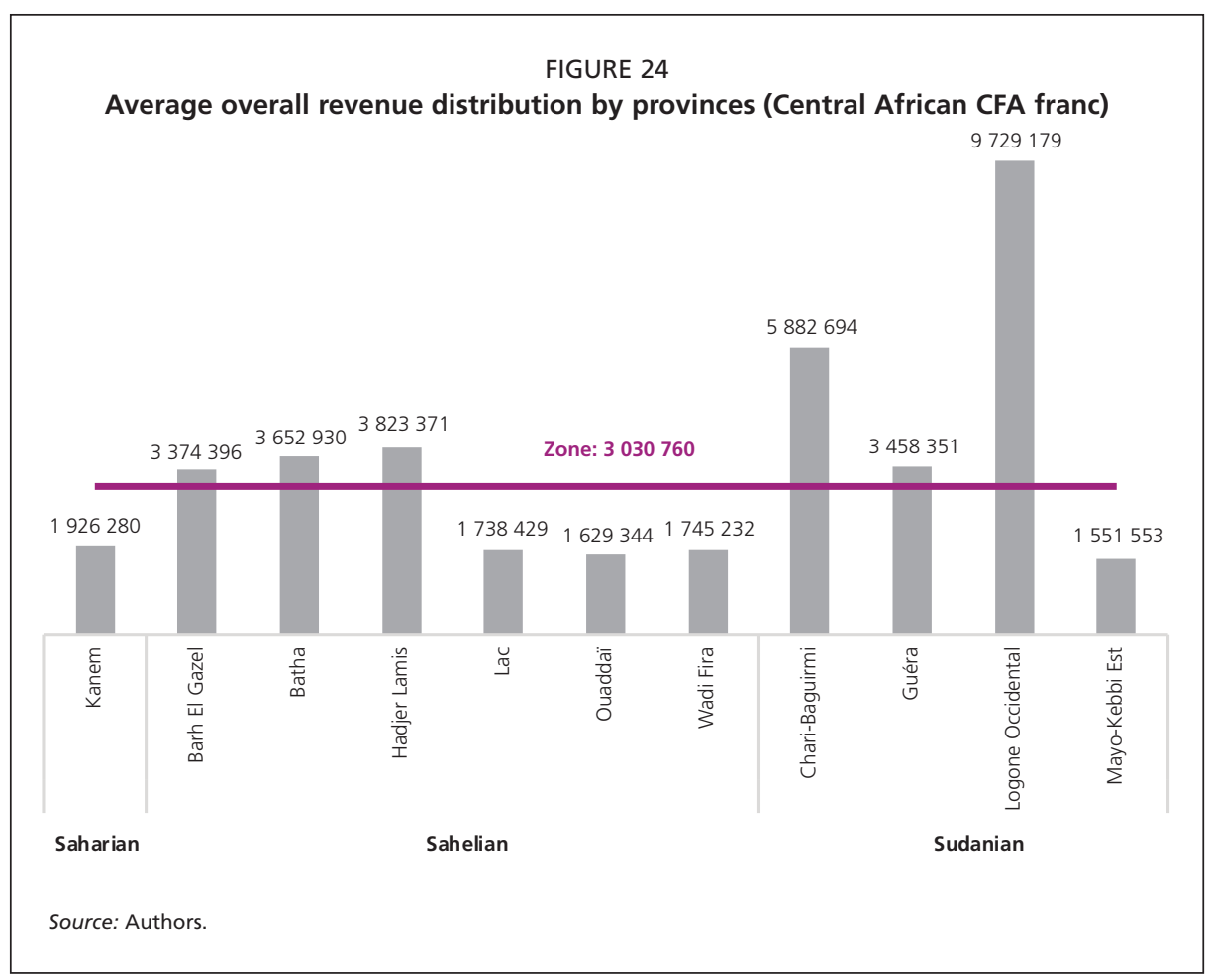


TABLE 6

Classification of households according to their overall average income

\begin{tabular}{lcccc}
\hline Category name & \multicolumn{2}{c}{ Low-revenue } & \multicolumn{2}{c}{ Lower-middle revenue } \\
\hline Range & Minimum & Maximum & Minimum & Maximum \\
\hline Revenue (XAF) & 57000 & 1092500 & 1092501 & 2002313 \\
\hline Category name & Upper-middle revenue & \multicolumn{2}{c}{ High-revenue } \\
\hline Range & Minimum & Maximum & Minimum & Maximum \\
\hline Revenue (XAF) & 2002314 & 3739600 & 3739601 & 16764725 \\
\hline
\end{tabular}

FIGURE 25

Disaggregation of the average overall revenue by province

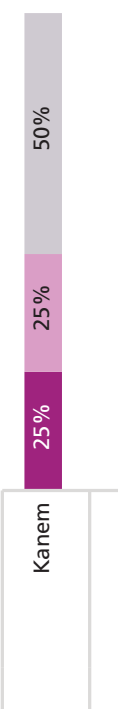

Saharan

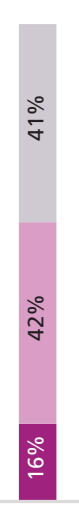

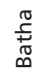

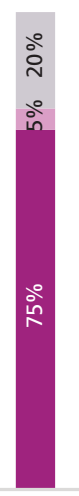

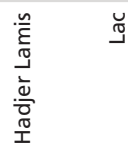

Sahelian

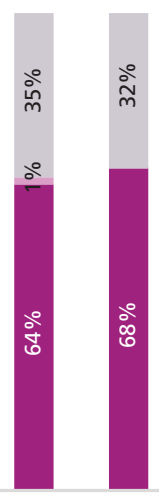

$\begin{array}{ll}: \frac{\pi}{7} & \frac{0}{2} \\ \frac{0}{0} & \frac{7}{0} \\ \frac{\pi}{3} & 3\end{array}$
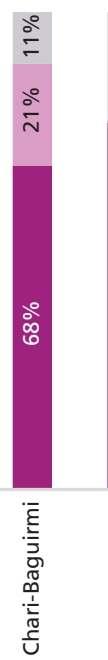
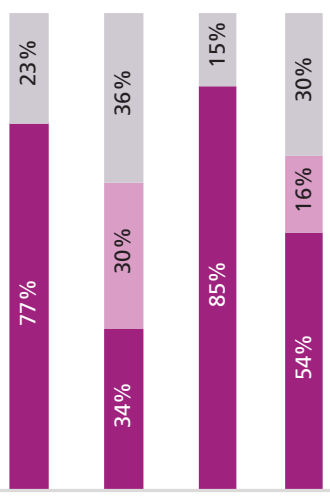

$\stackrel{0}{3}$

Sudanian

Livestock Revenue

Monetary Revenue

Self-consumption

A further analysis using deciles allows four categories of pastoral and agropastoral households to be distinguished according to their overall average revenue (low-revenue, lower-middle revenue, upper-middle revenue, and high-revenue) (Table 6). Livestock revenue remains the main source of cash income, accounting for $66 \%$ to $68 \%$ of overall average revenue for the first three categories (low-revenue, lower-middle revenue, and upper-middle revenue). The high-revenue category mainly derives its revenue from livestock, but to a relatively lesser extent (about $45 \%$ of total revenue). This latter category is also characterized by its ability to diversify its sources of revenue (25\% compared to $2-3 \%$ for the other categories) (Figure 26). High-revenue households are mainly located in the 
FIGURE 26

Breakdown of average revenue by household income category

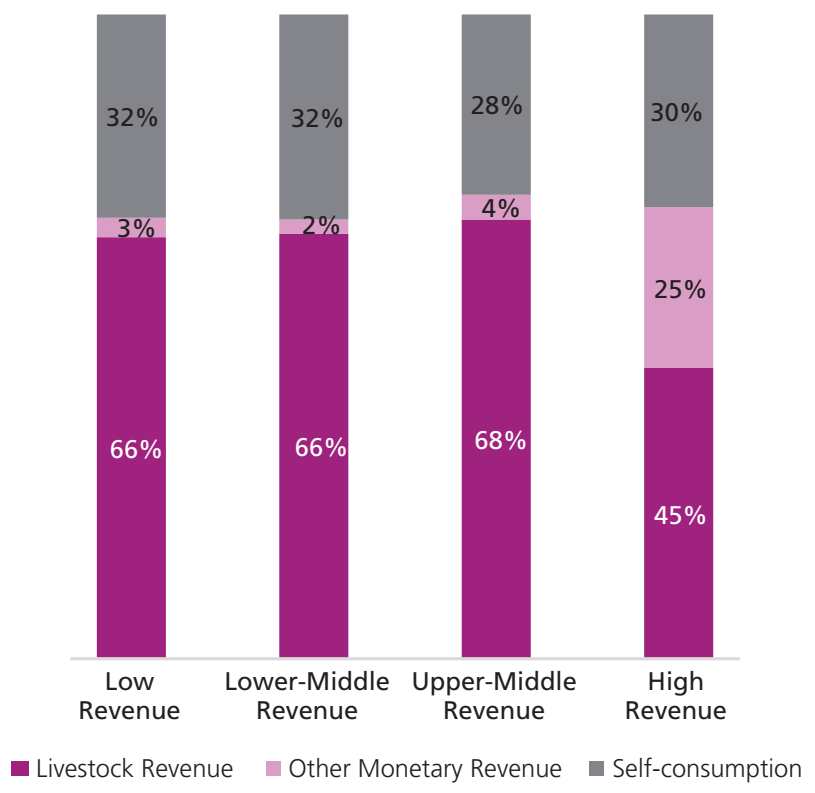

Source: Authors.

provinces of Logone Occidental, Chari-Baguirmi, Batha, and Hadjer Lamis. These provinces facilitate the diversification of activities, in particular crop activities, as the Sudanian zone favor the development of agricultural activities. High-revenue households also are found in Hadjer Lamis province, which is closer to N'Djamena.

\section{PASTORALISM AND DIRECT PRODUCTION COSTS}

Pastoral and agropastoral households in Chad use their cash income to purchase food and non-food items. In this survey, we focus on direct production costs, or intermediate consumption expenditures, in order to be able to ultimately analyze them with comparable concepts.

The average annual expenditure is XAF 815153 per household (Figure 27). These expenditures vary according to the location of households, with higher average amounts in the Sudanian zone, particularly in the provinces of Logone Occidental and Chari-Baguirmi. This may be the result of additional costs from crop activities.

Furthermore, expenditures related to animal health constitute an important spending item (27\% for the study area).

The budget dedicated to the restocking of herds is also important and accounts for $26 \%$ of expenditures. The purchase of animals increases with the category scale: the higher the household category, the higher the budget devoted to the purchase of animals (Figure 28). 
FIGURE 27

Distribution of average expenditures by province (Central African CFA franc)

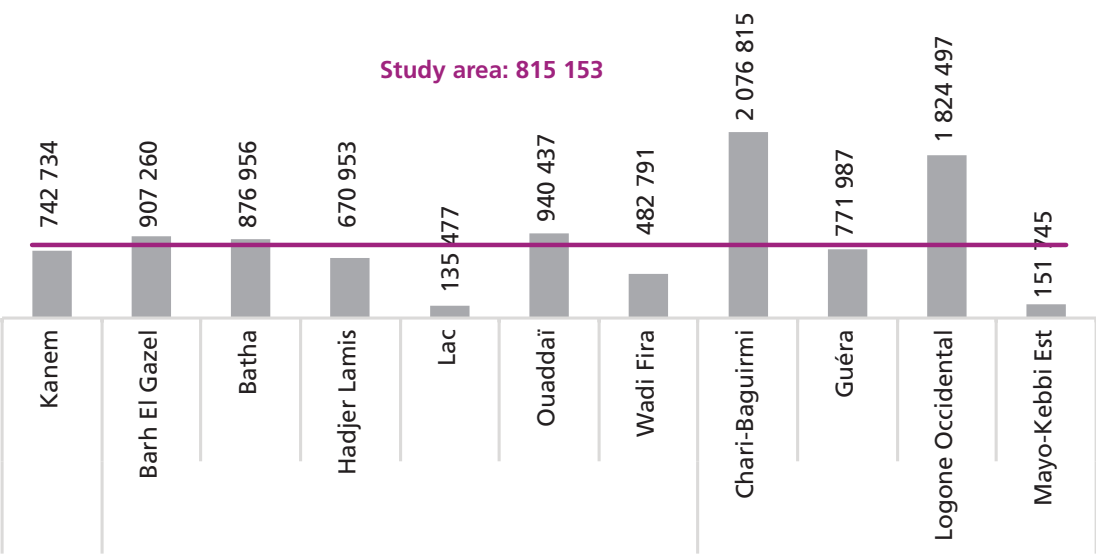

Saharan

Sahelian

Sudanian

Source: Authors.

FIGURE 28

Breakdown of average expenditures by household category

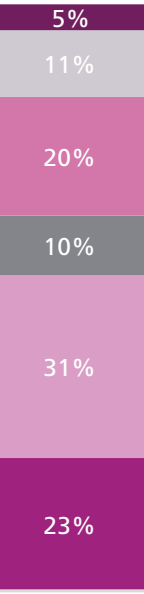

Low revenue

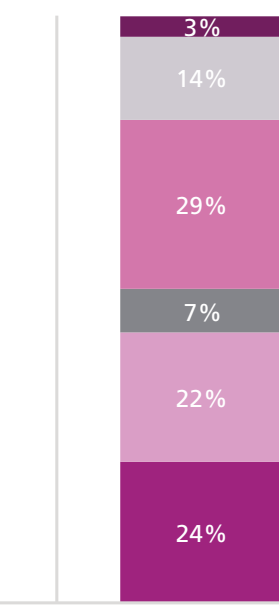

Lower-middle revenue

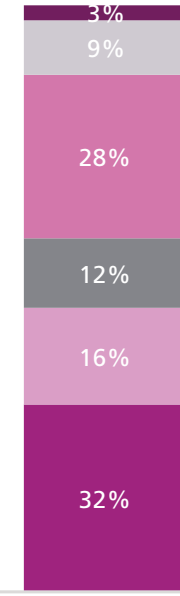

Upper-middle revenue

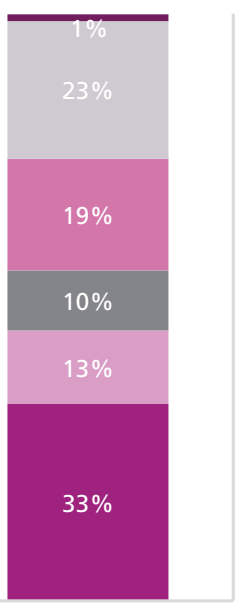

High revenue
Animal purchase
Feed
Animal watering
Animal health
Services
Taxes

Source: Authors. 


\section{PASTORALISM AND WEALTH CREATION}

The value-added approach, under which GDP is considered to be equal to the value of all goods produced in all sectors minus the value of all purchased intermediate goods used for production (i.e. intermediate consumption) was implemented in this study to provide insight into the direct contribution of pastoral and agropastoral households. The value added of a production unit reflects the amount of economic value of the primary factors of production used in the production process. The value added is calculated by subtracting the direct pre-tax charges from the pre-tax turnover for a given period. As we have done for Argentina and will do for Mongolia, we describe three main scenarios.

In scenario 1, the base-case model, pastoral and agropastoral households contribute $11 \%$ of the GDP, and $24 \%$ of the agriculture GDP.

In scenario 2, incorporating the significant self-consumption in Chad, the same households contribute $27 \%$ of the GDP, and $61 \%$ of the agriculture GDP.

In scenario 3, the contribution of pastoralists to GDP and agriculture GDP declines to $1 \%$ and $3 \%$ (without self-consumption) and $18 \%$ and $40 \%$ (with self-consumption) assuming an average holding period of animals sold of two years. This contribution drops substantially to reach negative figures when the average ownership of animals sold is three years, $-8 \%$ and $-18 \%$ (without self-consumption). This contribution is maintained positive but at a lower level when self-consumption is incorporated: $9 \%$ and $19 \%$ (Figure 29).

\section{PASTORALISM AND REVENUE DISTRIBUTION}

The revenue distribution of pastoral and agropastoral households in the study area appears particularly unequal across this Lorenz curve with a high concentration area.

These revenue inequalities are reflected through a global Gini index in the zone of around 49.6 above the national level assessments, resulting in a Gini index of 44.0 (World Bank, 2016). Self-consumption contributes to the attenuation of inequalities with a Gini index slightly decreasing from 0.496 to 0.483 . Although self-consumption in Chad is higher than in Argentina, there is no mechanical effect of self-consumption in the Gini index (Figure 30).

\section{PASTORALISM AND MULTIFACETED SHOCKS}

In the context of Chad's pastoral and agropastoral systems, idiosyncratic shocks are reported most, accounting for $51 \%$ of the total, versus $43 \%$ for covariate shocks. The remaining $6 \%$ are attributable to a combination of various shocks.

Among the idiosyncratic shocks most reported by investigated households are the occurrence of animal diseases, conflicts and livestock thefts (Figure 31). At the agroecological levels, there are notable differences. In the Sahelian zone, the occurrence of conflict or violence is the most frequently reported shock by pastoral households (32\%). This may be due to regular tensions between different communities, notably in the eastern part of the country.

In the Sudanian zone, the idiosyncratic shock with the highest occurrence is related to animal diseases. Rainfall conditions in southern Chad may be conducive to the emergence or reinforcement of animal diseases.

The Saharan zone, together with the Kanem region, report no idiosyncratic shocks. 
FIGURE 29

Direct economic contribution to GDP and Ag. GDP

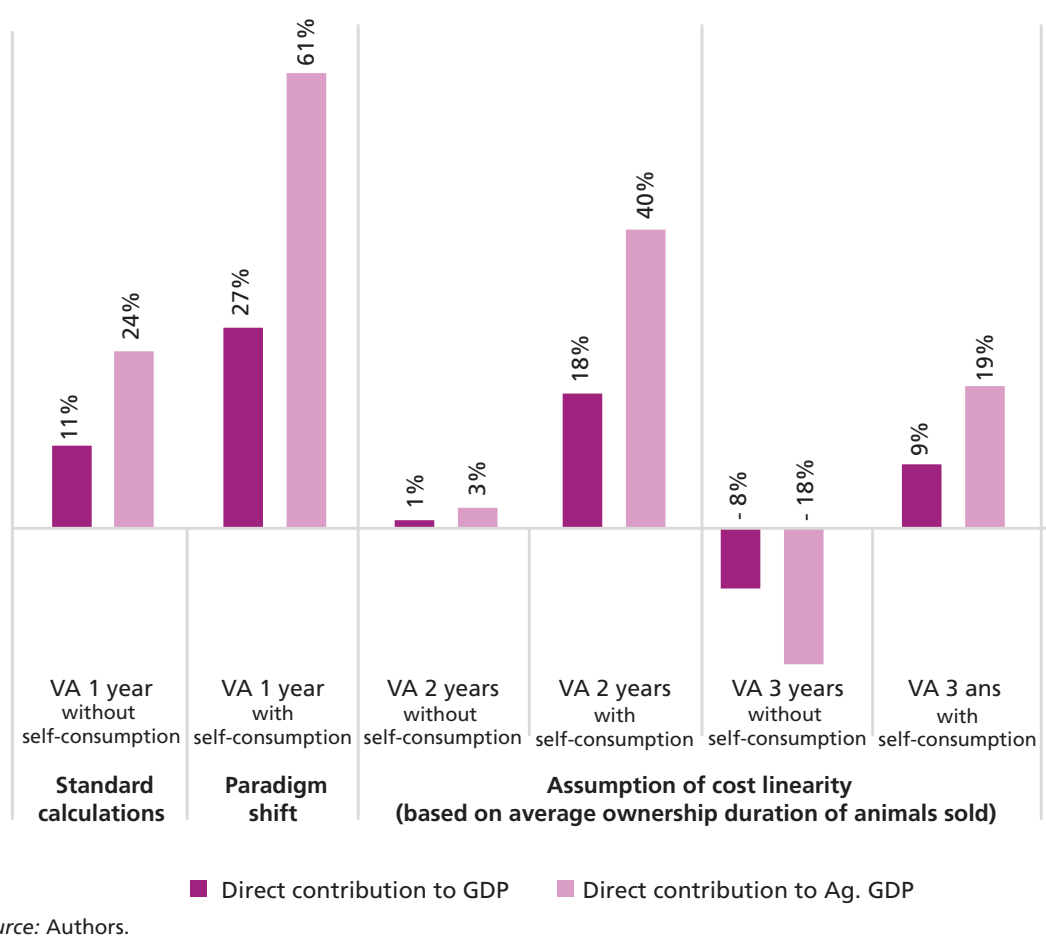

FIGURE 30

Distribution of monetary and gross revenue

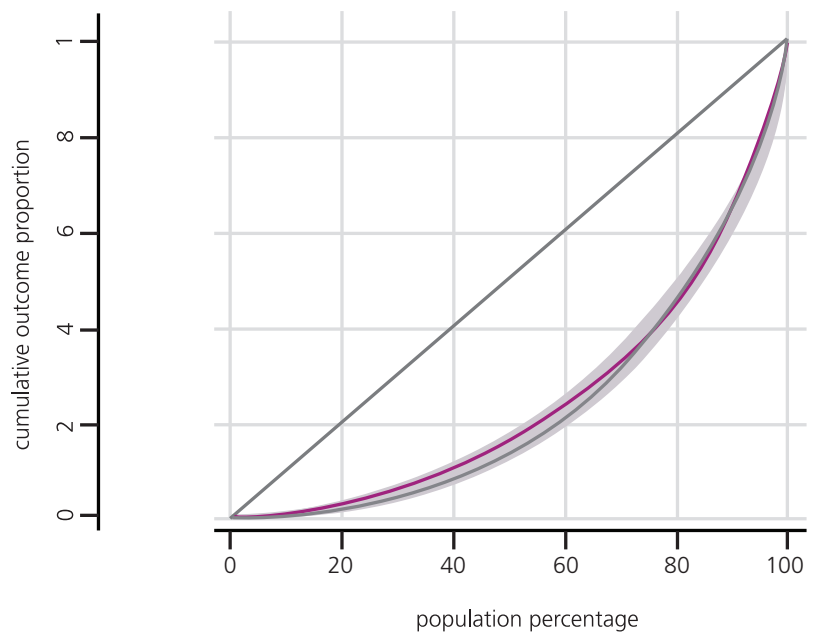

Monetary revenue (0.496)

Gross revenue (0.483)

Source: Authors. 


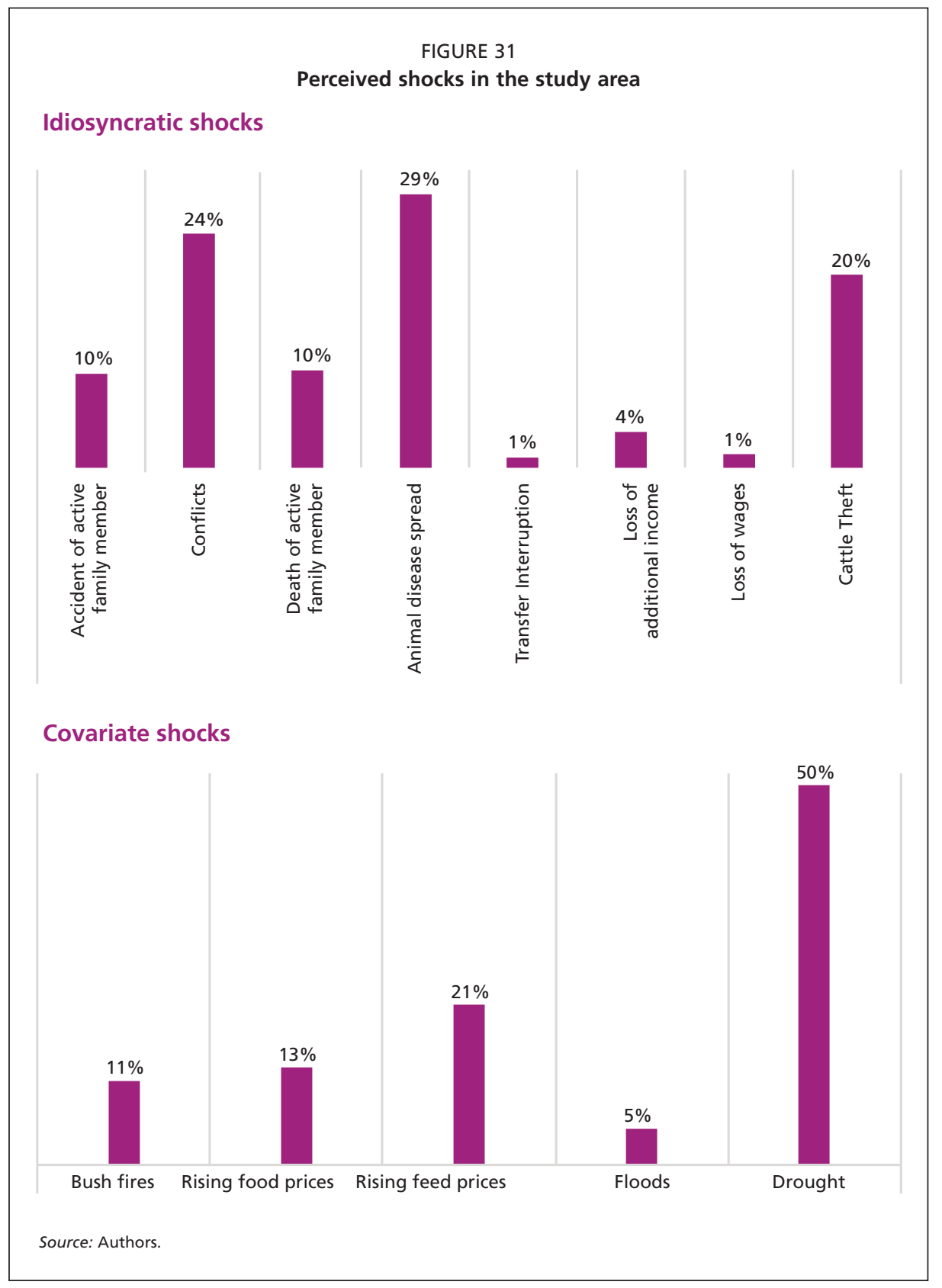

The covariate shocks are dominated by climate change with the recurrence of drought in the study zone (50\% of responses). Pastoral and agropastoral households resort to the purchase of livestock feed, the price increase of which is reported as the second-most important covariant shock (21\%). 


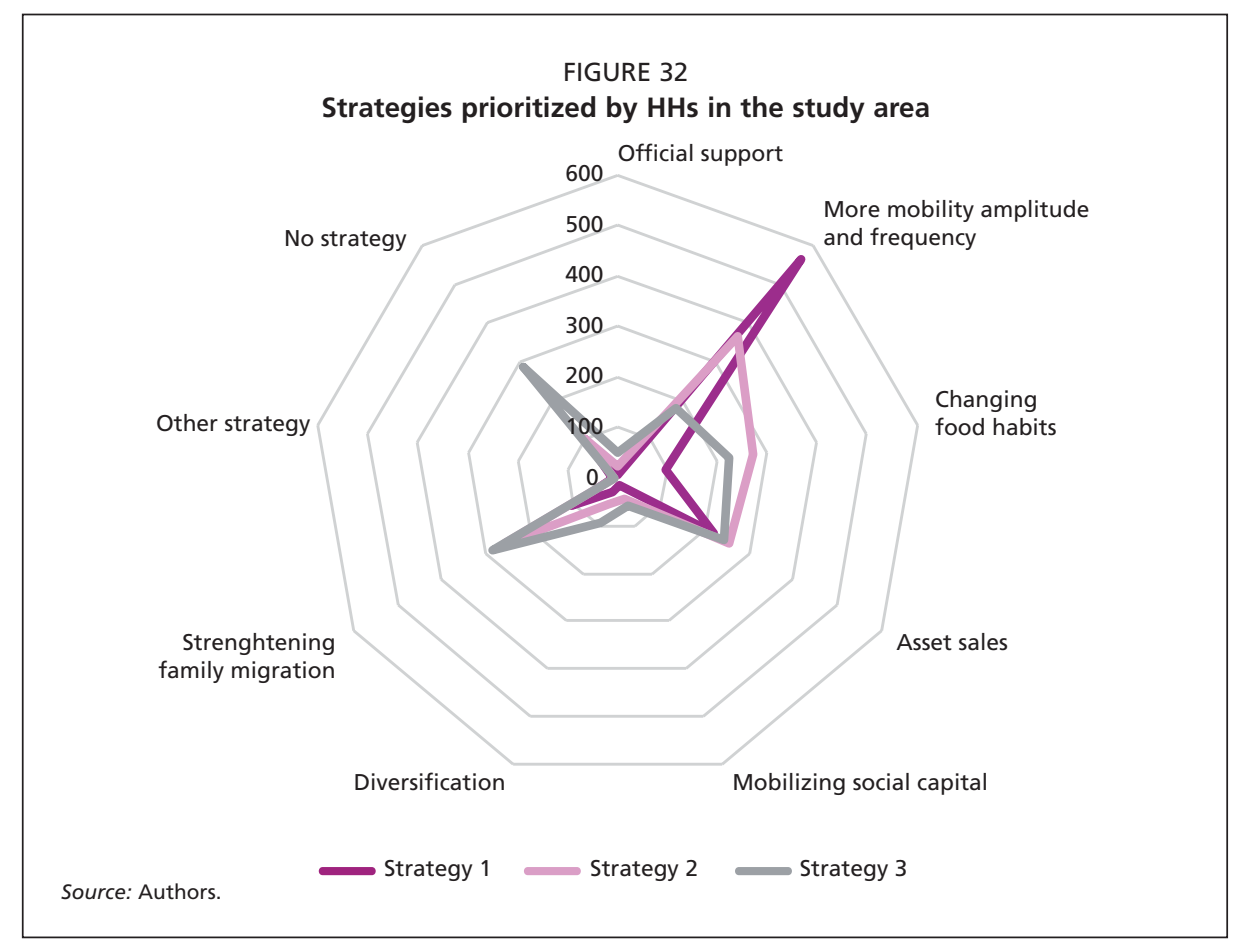

More specifically, in the agroecological zones, the proportion of households reporting drought as the main covariate shock is higher in the Sahelian zone than in the Sudanian zone $(59 \%$ versus $42 \%)$.

\section{PASTORALISM AND CONTINGENCY STRATEGIES}

In this shock-prone context, pastoral and agropastoral households have used a variety of strategies. The most significant at the level of the surveys are the adjustment of pastoral practices and sales and monetary arrangements. The main strategy adopted by households involves increasing the amplitude and frequency of mobility. Faced in particular with a climate shock, pastoral and agropastoral households are resorting to transhumance as their main strategy, moving toward host areas further south in Chad by mobilizing more family labor or relying on salaried herders. The other preferred strategy is increased sales of livestock in a system where livestock capital is the main asset (Figure 32). The two main strategies used by pastoral and agropastoral households show the low dependency on external support mechanisms. The use of mobility and livestock sales on a larger scale shows the willingness of pastoral people to rely on their own assets, and highlights the resilience capacities in these systems. There were few reports of strategies involving reliance on government support or subsidy programs. 


\section{Mongolia}

\section{BACKGROUND AND MACRO CONTEXT}

Located in the heart of Central Asia, Mongolia had high economic growth rates in 2011 and 2012 before experiencing a macroeconomic crisis that lasted until 2017. Persistent economic imbalances sharply affected the country. Efforts made to reduce poverty in 2011 and 2012 appeared to be in vain, with a decrease in the key drivers of the economy: foreign direct investment and private consumption. The Mongolian authorities implemented strong economic adjustment measures to improve the fiscal balance. According to the World Bank (2019), the deficit declined from 15.3\% of GDP in 2016 to a surplus of 2.6 in 2018 and 3.4 in January-July 2019 (Figure 33).

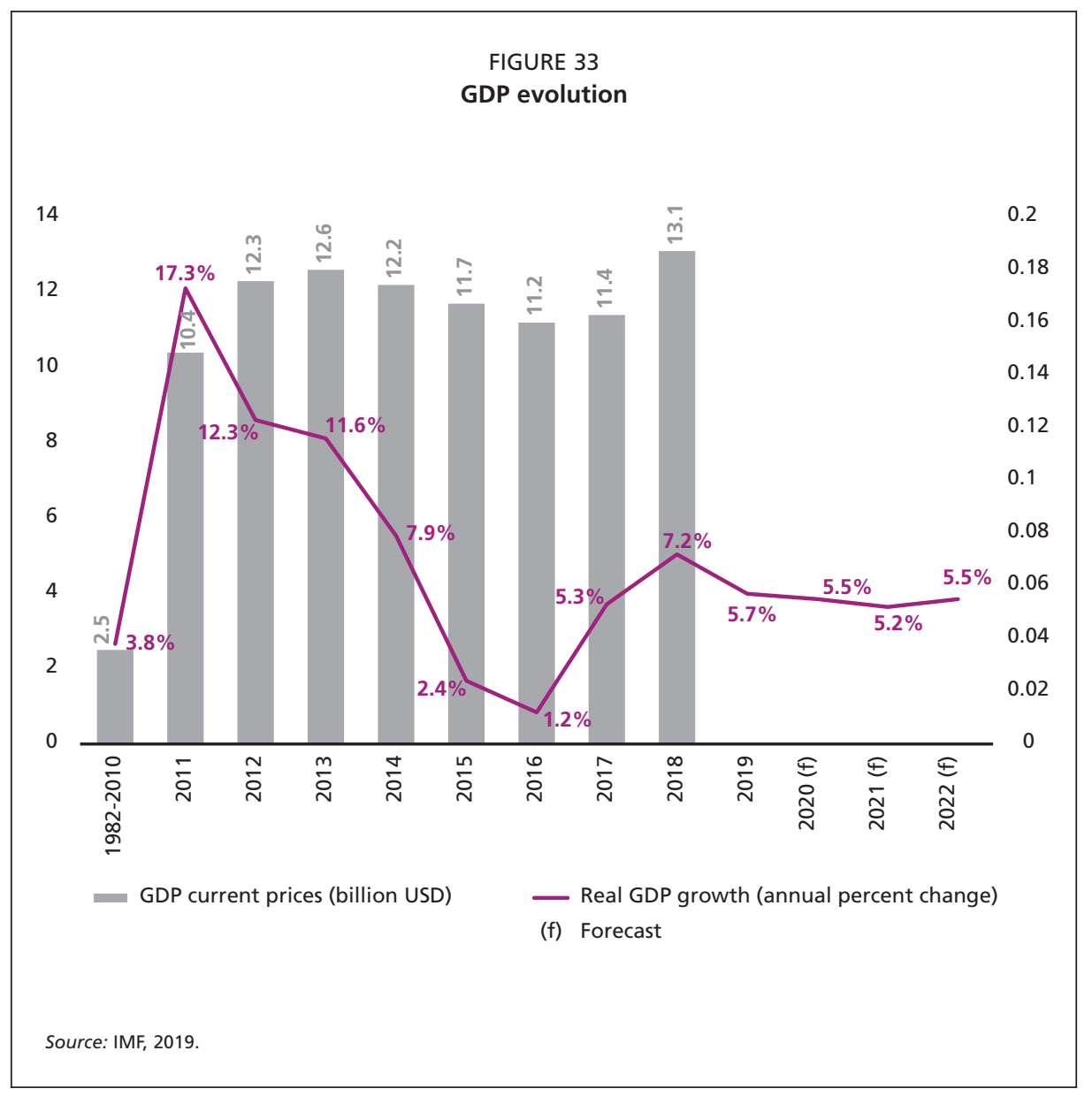




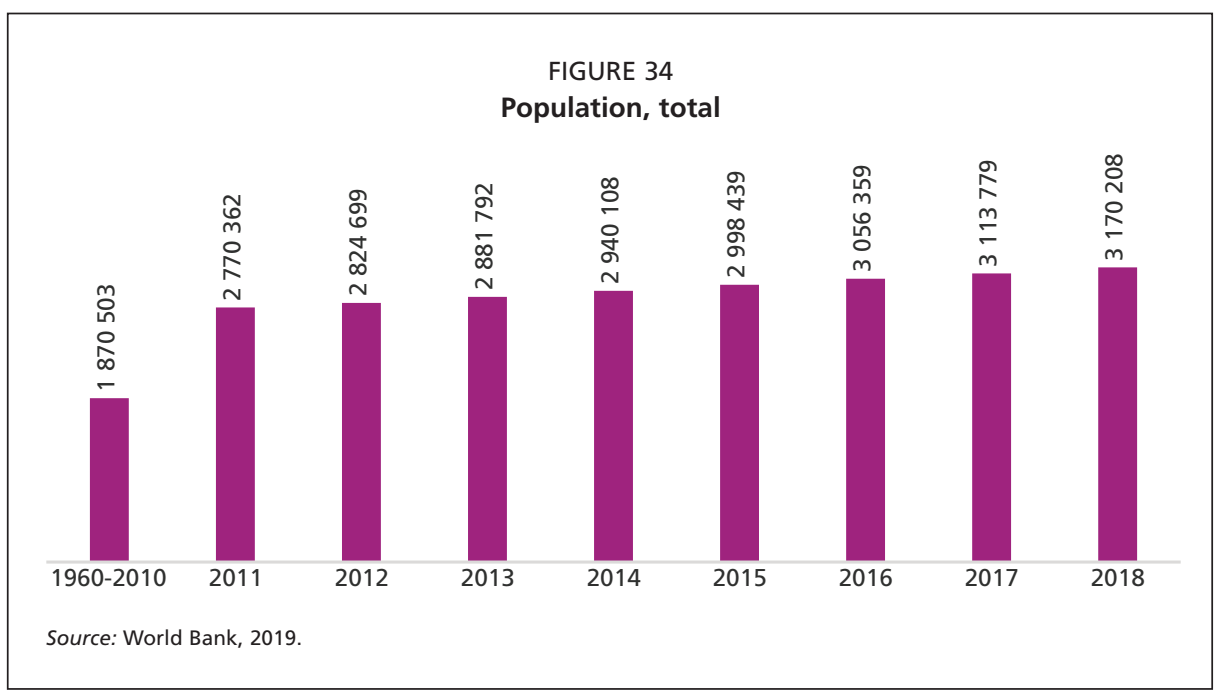

Like most small commodity exporters, growth is expected to decelerate, but remains relatively strong in Mongolia (due to vigorous private consumption and mining sector investment). Mongolia remains the least densely populated country in the world, with an overall population density of 1.7 per square kilometer (3.2 million people sparsely distributed over 1.6 million square kilometers) (Figure 34).

Despite strong economic imbalances, the Mongolian authorities continue to prioritize the agricultural sector. Given its multiple functions (food security, cash revenue, export revenues, employment, landscape management, etc.), the livestock sector deserves close attention. In recent years, the government has focused more on the intensive development of the food and agricultural sector, emphasizing increased production and productivity and reduced vulnerability to climate, market and social challenges.

The Mongolian livestock sector has drastically changed since 1990, when the country started its transition toward a market economy. Between 1991 and 2018, the total number of ruminants soared from 26 to 66 million heads. This pastoral boom has been mainly due to a sharp rise in small ruminants. During this period, the number of goats multiplied by 5.4, reaching 27 million heads. The sheep herd doubled, reaching 30 million heads (NSO, 2019) (Figure 35). This "small ruminant revolution" has shown the ability of pastoralists to adapt to the new market context, taking advantage in particular of high demand for wool, meat and cashmere. At the same time, the extension of the national herd has threatened the capacity of the rangeland to support this new grazing pressure. The rise in small ruminant herds has also increased the vulnerability of herders facing exceptional climate events. The $d z u d^{4}$ that arose in 2000-2002 resulted in a 30\% decline in the national herd. And the dzud that came in 2009-2010 had the same dramatic consequences. The collapse of the former socialist institutions based on collective solidarity and public support (such as local

4 Over the past two decades, Mongolia has been hit by two extremely severe winters, which caused mass livestock mortality. The phenomenon of harsh winters causing mass livestock mortality is referred to as $d z u d$ in the Mongolian language. Extreme winters are characterized by exceptionally cold temperatures, excessive snow, lack of precipitation during the previous summer and fluctuations in temperature that cause the snow to melt and then ice over, thus hindering animals from grazing. 
FIGURE 35

Animal population in Mongolia

35000

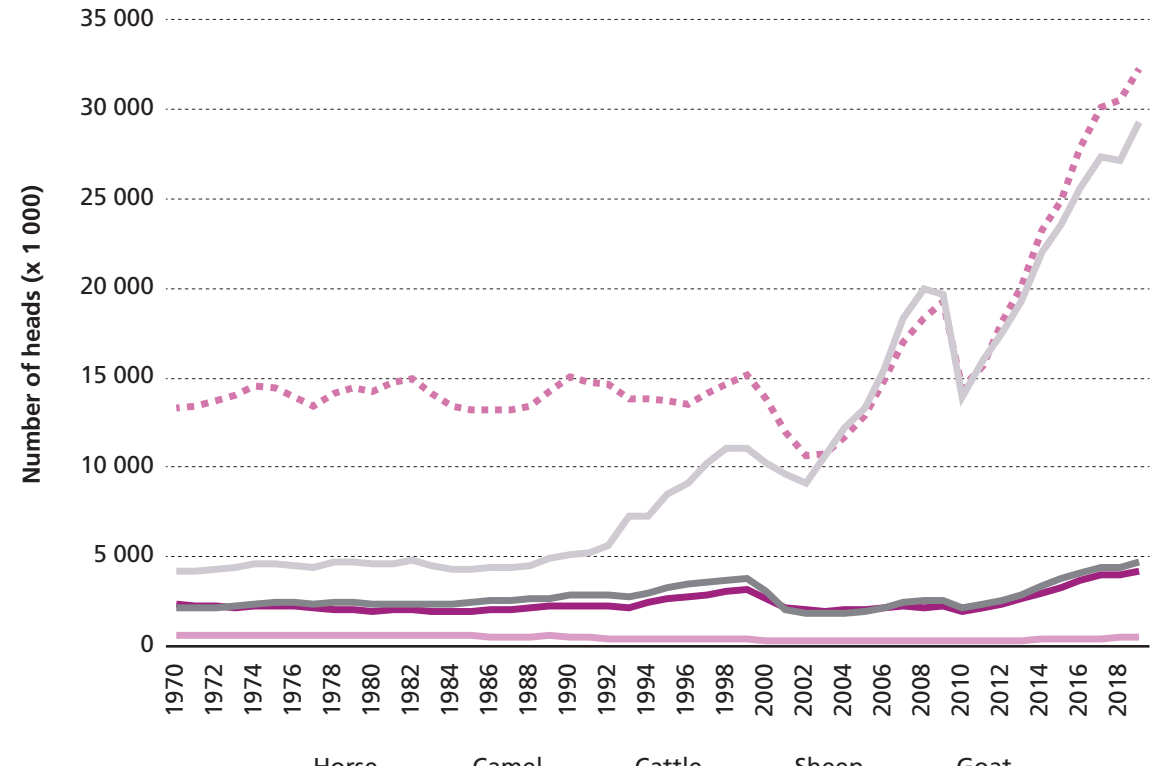

Source: NSO, 2019.

cooperatives called negdel) has increased the vulnerability of pastoralists facing climate irregularity.

In this context, pastoral organizations such as the NFPUG, should play a stronger role in promoting solutions for a more sustainable management of rangeland and animal product value chains. The collection of accurate data on the pastoral household economy is in particular needed to support the capacity of these organizations to propose sustainable development policies and strategies.

\section{DATA COLLECTION AND MANAGEMENT: INCLUSIVENESS OF PASTORAL ORGANIZATIONS}

In Mongolia, the study was conducted in partnership by the PKH, CIRAD and NFPUG. NFPUG is a federation of herders working in Mongolia with several national and international partners (such as the Swiss Cooperation, the World Bank, the European Union, the United Nations Development Programme, etc.), and has been implementing several projects and programs related to pastoralism, with a focus on preventing land degradation.

PKH and CIRAD were in charge of the survey design, and NFPUG was in charge of survey implementation and data collection. All three partners worked together on data analysis under the leadership of CIRAD. Two complementary surveys were conducted as indicated below.

From March to June 2018, the team conducted an initial exploratory survey on a large sample of households to broadly characterize the pastoralist population. 


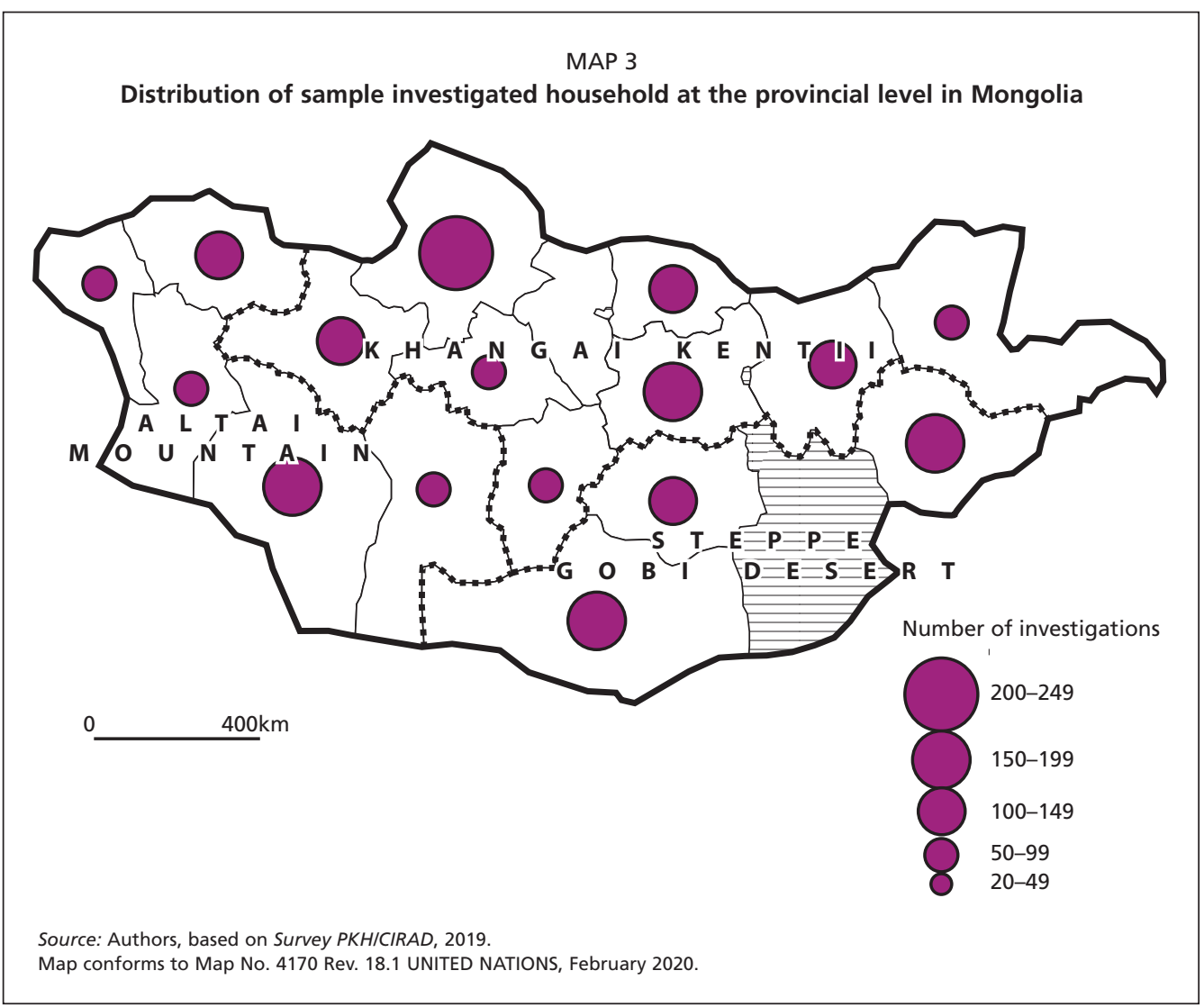

In total, more than 100000 pastoral households were surveyed in 159 sums (an administrative subdivision in Mongolia where 'Pasture User Groups are registered). This sample represents around $30 \%$ of the total households registered nationally, and around $50 \%$ of the 333 sums reported in Mongolia (Map 3).

In 2019, a second in-depth survey was conducted on a representative sample of 764 households to collect household economics data. The explanation of the sample size is mentioned in the introduction (Table 1).

\section{PASTORALISM: REARING OF VARIOUS ANIMAL SPECIES}

Pastoralism is a thousand-year-old land use activity in Mongolia. Despite the changes observed, Mongolian pastoralists continue to manage livestock today in a way that is centuries old. Grazing systems are transhumant with winter bases to protect the livestock from harsh winter conditions.

Herding is the main economic activity in rural Mongolia. Mongolian herders typically hold multi-species flocks composed of different ruminant species, including horses, cattle (and yaks), sheep, goats and camels (the five "muzzles"). Herders typically own a mix of species well adapted to the extreme continental climate of Mongolia. According to the National Statistics Office of Mongolia, the country owned 4388455 cattle; 434096 camels; 30109888 sheep; 27346707 goats; and 3939813 horses in 2017. 


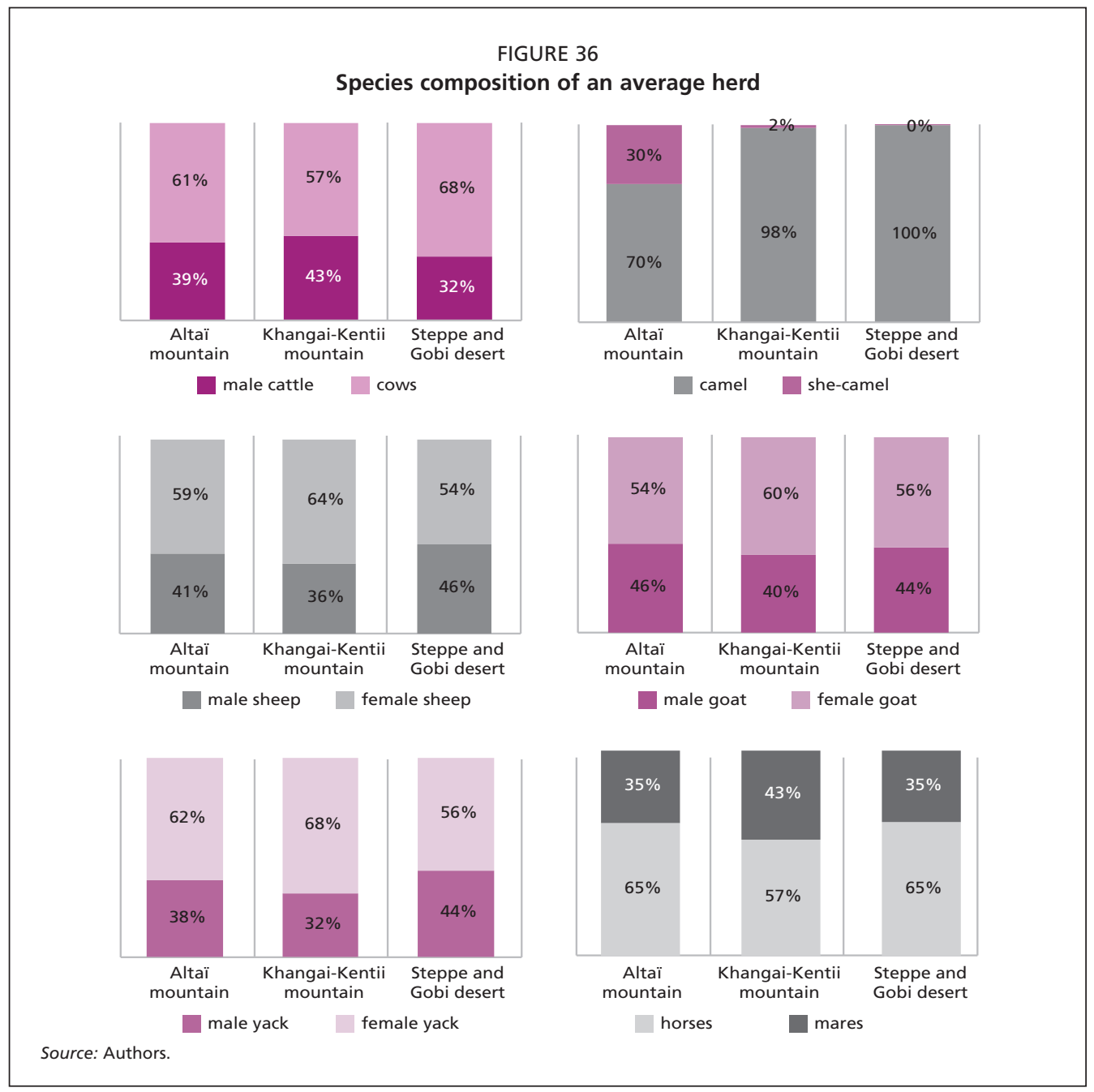

Cattle are mainly reared for the production of milk and dairy products. Cattle herd stocks remain more than $60 \%$ female dominated and contribute to household production objectives.

The trends observed for cattle are reversed for camels, which remain overwhelmingly or even totally dominated by males. In the Steppe and Gobi Desert, the declared herds are made up entirely of males. This is almost the case in the Khangaï-Khentii Mountains (98\% males) and to a lesser extent in the Altaï Mountains (70\%).

Small ruminants are constituted by sheep and goats. Sheep provide most of the meat for households' subsistence needs. Households have a net preference for mutton for their main meals. Goats play an important role as cashmere becomes the main source of cash revenue. There is a slightly superior proportion of females in the small ruminant herd.

As with camels, horses are an element of prestige but also are hoarded. Both species play an important role in the transport of goods and people during long migrations. For this reason, males are preferred for these two species in family herds. (Figure 36). 
All animal species are sold (alive, slaughtered, as well as their skins and hides) when the need arises. The proportion of each species varies in time and space. FAO has provided a LSU as a convenient way for the aggregation of livestock from various species. In Mongolia, animals are traditionally compared to each other, with 1 horse being equivalent to 1 cattle, 7 sheep, 10 goats and 0.67 camels. FAO recommends some slightly different conversion rates, with 1 horse equivalent to 1 cow, 7.5 sheep, 7.5 goats and 0.8 camels. However, Mongolian authorities are using an alternative measure for the aggregation of various species, the Sheep Forage Unit (SFU), which seeks to standardize livestock grazing by placing different species as sheep equivalents. In Mongolia, SFU per type of animal is 5 SFU per camel, 7 SFU per horse, 6 SFU per cow or yak, and 0.9 SFU per goat.

Our sample household surveys show that average animal ownership is 78 LSU or 757 equivalent sheep. This would be equivalent to considering that households own on average 12 male cattle, 17 cows (note that cattle include yaks) 2 camels, 77 male sheep, 116 female sheep, 74 male goats, 99 female goats, 19 horses, and 13 mares.

Households in Khangaï-Khentii are better endowed with live animals than the two other major agroecological zones. Pastoralists' needs of space depend a lot on the ecological characteristics of land. Those living in Gobi arid lands cover greater distances. The process to develop protected areas and the potential for a much larger area to be placed under protected status are creating real opportunities that will benefit local pastoralists.

Most protected areas in Mongolia allow grazing by domestic livestock, and even areas that prohibit livestock by law remain largely unmonitored and pastoralists continue to use most of these areas, at least periodically. However, the emergence of mining activities has affected land conservation and pastoralists have been strongly constrained in their production activities. In the Altaï Mountains region, pasture conditions have been deteriorating over the past 20 years. The pastures in the high valleys, where the nomad families live, increasingly offer insufficient forage for the livestock (Figure 37).

\section{PASTORALISM AND REVENUE GENERATION}

The annual gross revenue of the households interviewed is estimated to be MNT 11.8 million per household, and incorporates all sales realized by the household as well as self-consumption, wages and salaries, transfers and exceptional items.

The average annual total revenue of households based in the Steppe and Gobi Desert and Khangaï-Khentii Mountains regions, representing 70\% of the households in the survey area, was around MNT 12.7 million, which is largely superior to those of households in the Altaï Mountains area (MNT 8.9 million) (Figure 38).

The total revenue is dominated by cash revenue generated from the sale of live animals and livestock products: $74 \%$ in the survey area, $76 \%$ in the Altaï Mountains, $67 \%$ in the Khangaï-Khentii Mountains, and $88 \%$ in the Steppe and Gobi Desert.

Self-consumption contributes $10 \%$ of the total revenue. The use of production for self-consumption is most significant in the Khangaï-Khentii area (17\%), while relatively marginal in the Altaï Mountains (6\%). The households surveyed in the Steppe and Gobi Desert did not reveal any recourse to self-consumption. This was questionable and surprising as camel herders usually depend on meat and milk self-consumption. 


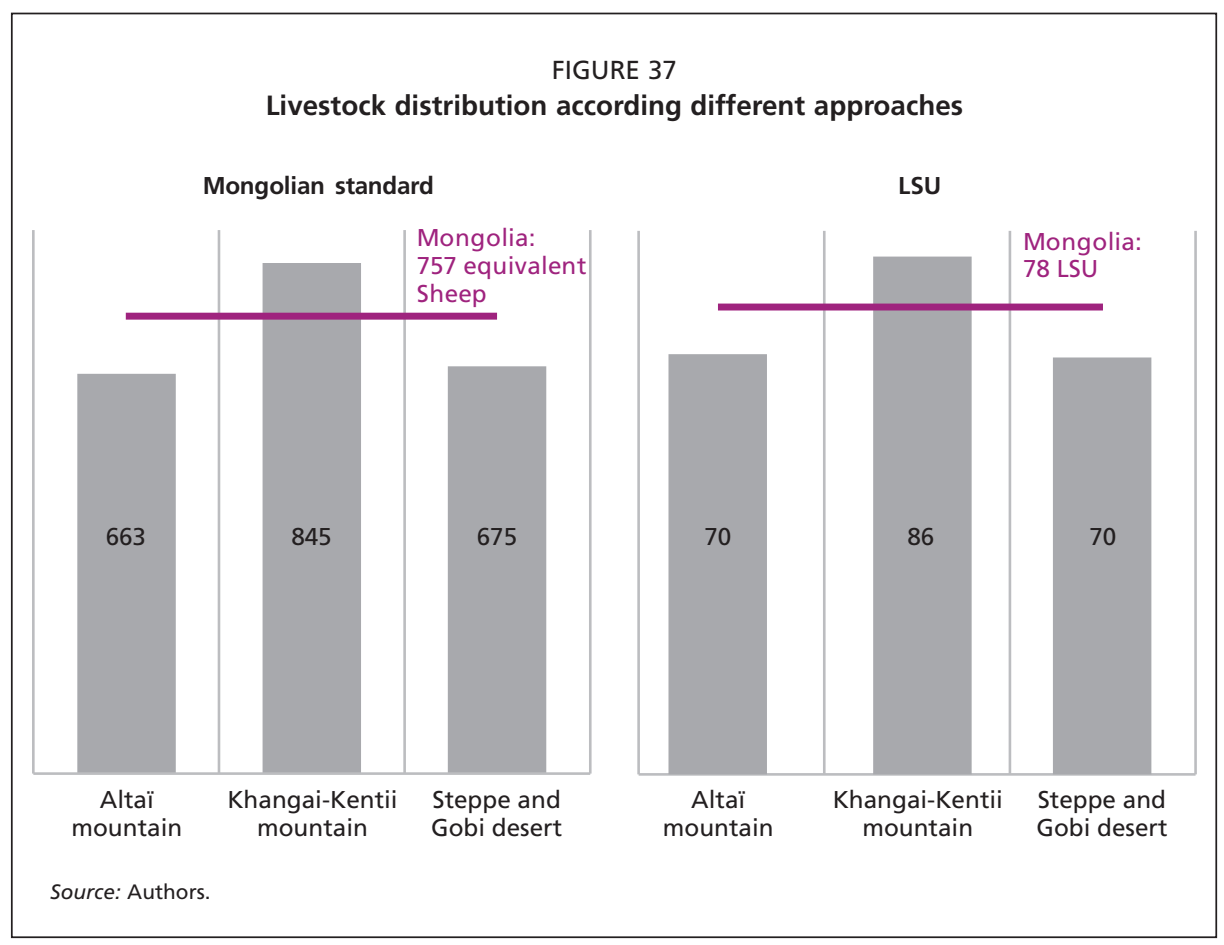

FIGURE 38

Some average revenue indicators (Mongolian Tugrik)

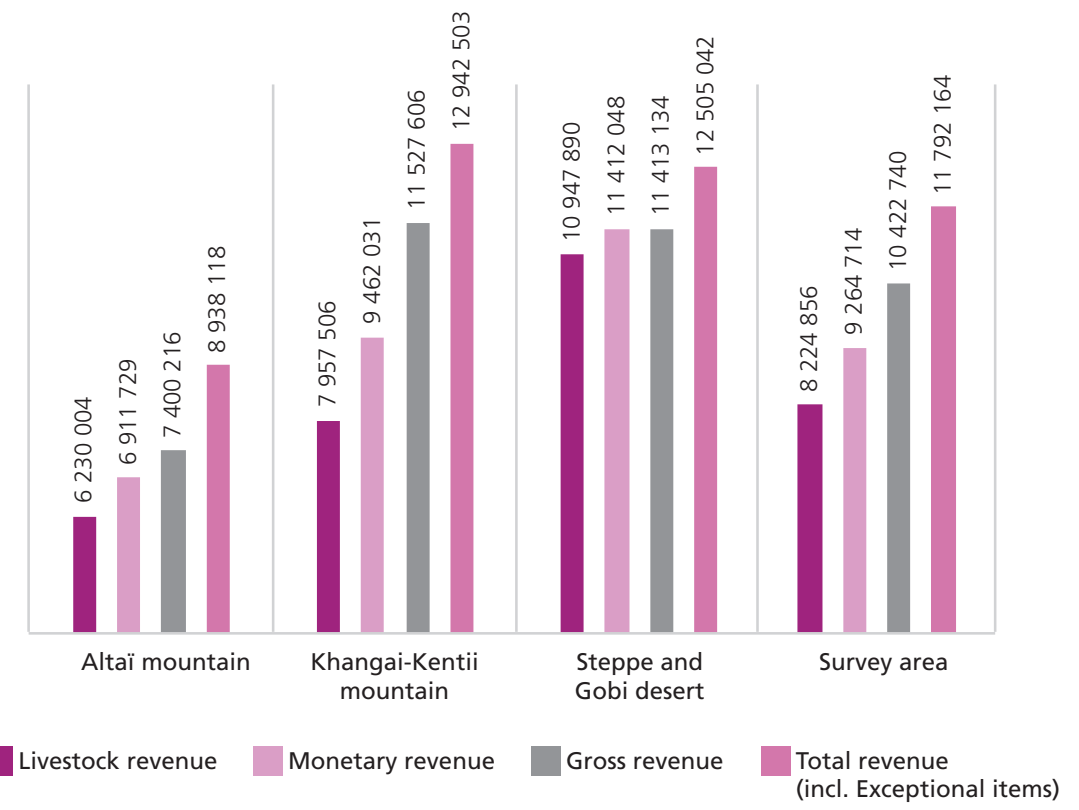

Source: Authors. 
Looking more closely at the revenue generated by the sale of livestock products, live animals remain the main source of cash, accounting for $88 \%$ of the total revenue. The sale of other animal products (including fibers) account for only $12 \%$ of total household revenue. In addition, the sale of livestock products is not marked by a seasonal pattern with the exception of the Steppe and Gobi Desert, where the warm season seems to be more conducive to trade.

Agricultural products present a different situation, as goods are traded during the warm season, although in the Altaï Mountains slightly less than a third of sales take place in the cold season. There are no sales of agricultural products in the Steppe and Gobi Desert.

The other sources of monetary revenue are dominated by wages (57\%) and other sources of revenue (37\%). The development of extractive industries offers wage-labor opportunities in the Steppe and Gobi Desert and Khangaï-Khentii Mountains. To a lesser extent, households of the Altaï Mountains rely on wages. Transfers are weak (7\%).

Almost similar to self-consumption, exceptional items, made up of subsidies, loans and other sources of revenue, represent $8 \%$ in the survey area. Overall, the exceptional items mostly come from subsidies and loans. The government supports all Mongolian citizens by providing each of them a per capita grant. This financial annuity represents almost half of the exceptional items received by households (47\%). This support can be very significant $(98 \%$ in the Steppe and Gobi Desert) while others declare also having access to loans (Figure 39).

Sales of livestock products play a key role in the total revenue for all categories. Their contribution increases from the low-revenue (18\%) to lower-middle revenue (40\%), upper-middle revenue (59\%) and high-revenue (82\%) categories.

The higher one goes up the household revenue ladder, the less recourse is made to exceptional items, which in turn decreases, contributing $78 \%$ of the total revenue of the low-revenue category and up to $4 \%$ of the high-revenue group (Figure 40).

These general trends, while instructive, hide important disparities from one aimag (administrative subdivision) to another.

\section{PASTORALISM AND DIRECT PRODUCTION COSTS}

The average annual expenditure is MNT 698653 per household (Figure 41). Production costs represent $83 \%$ of household annual expenditures.

Expenditures vary greatly according to the location of households, with higher average amounts in the Altaï Mountains (48\%), in particular in Govi-Altaï and Bayankhongor, as well as in the Khangaï-Khentii Mountains (37\%), notably in Arkhangai and Bulgan.

On average, the direct intermediate costs of households essentially come from the purchase of services (44\%) and live animals (37\%) to reconstitute and consolidate the family herd. The proportion of services in the household budget remains relatively very high. This expenditure, linked to the provision of services related to animal herding and marketing, can also be explained by the large size of the country, which also poses the problem of access to basic infrastructure and social services.

Overall, animal health and animal watering have lower costs. However, in the Steppe and Gobi Desert, animal watering puts a strong strain on household budgets (39\%) in comparison to other regions. In the Khangaï-Khentii Mountains and Altaï Mountains, budget components are relatively similar (Figures 41 and 42). 
FIGURE 39

Components of the annual total revenue by regions

Breakdown of total revenue

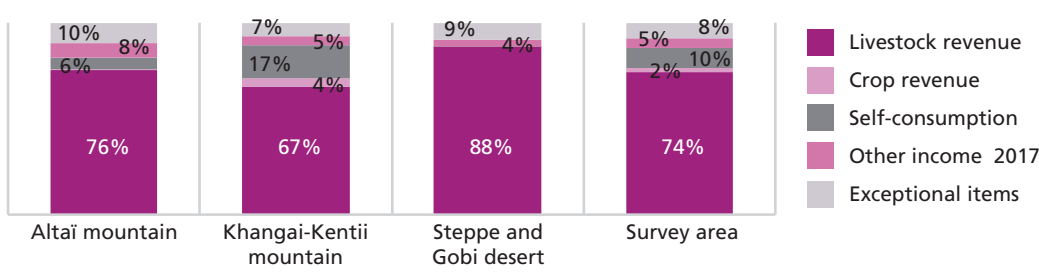

Breakdown of livestock income

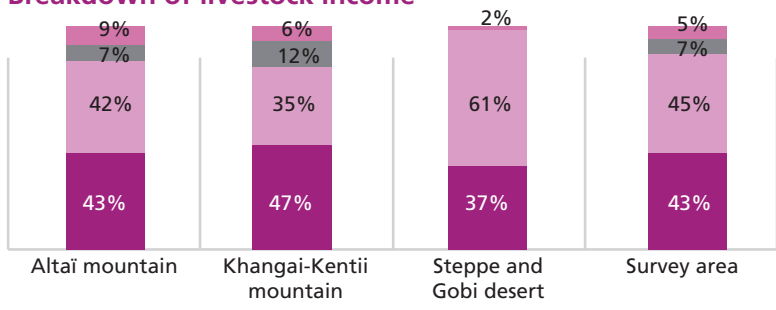

Other livestock products warm season

Animal sales warm season

Other livestock products cold season

Animal sales cold season

\section{Breakdown of agricultural products}

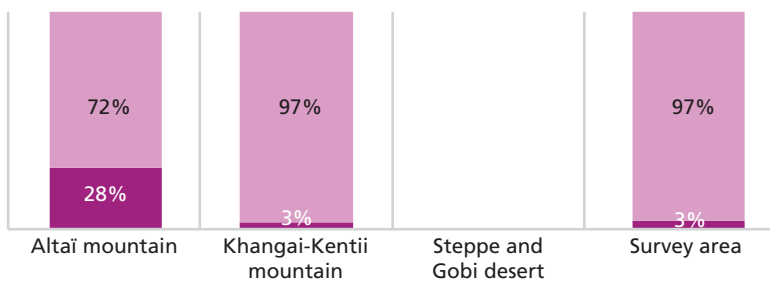

Sales of agricultural products cold season

Sales of agricultural products warm season

\section{Breakdown of other sources of income}
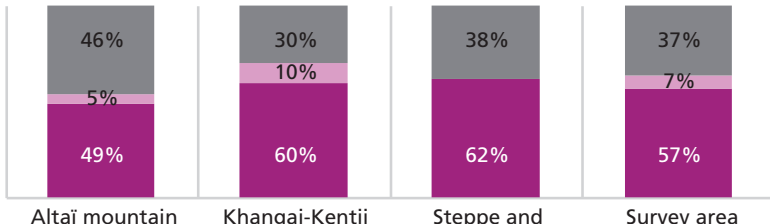

Wages 2017

Transfers 2017

Other sources of revenue 2017

Altaï mountain

Khangai-Kentii mountain

Gobi desert

Survey area

Breakdown of exeptional items

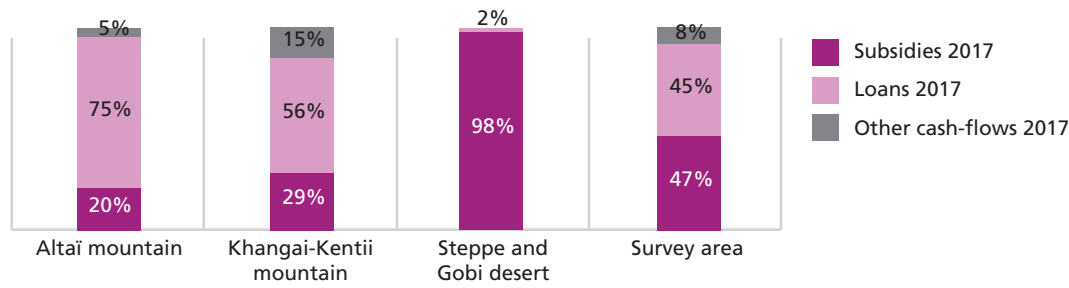

Source: Authors. 
FIGURE 40

Components of the annual total revenue by category of household

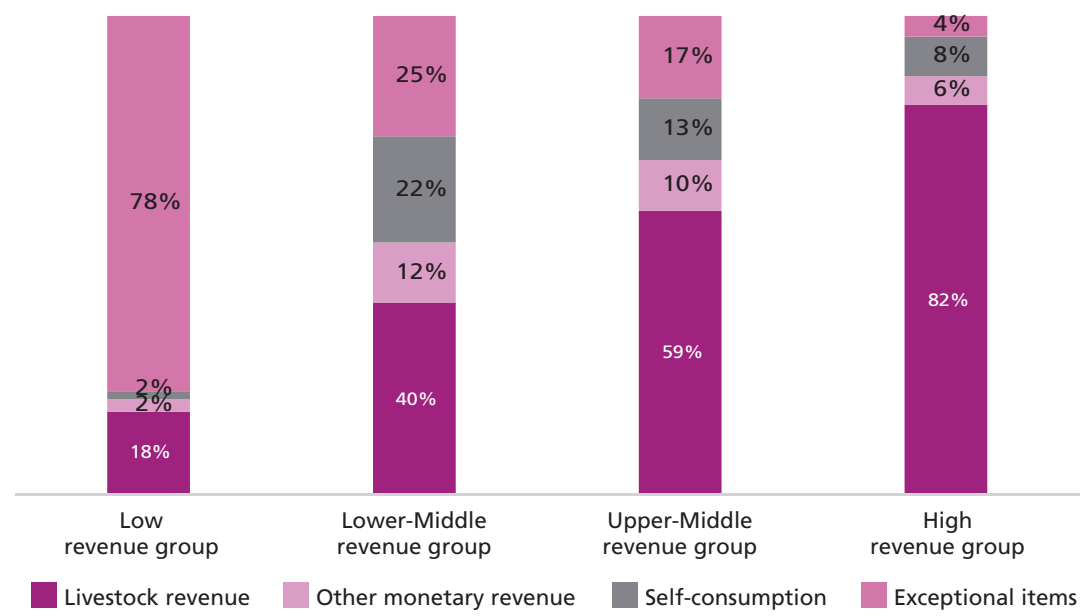

Source: Authors.

FIGURE 41

Direct production costs by regions (Mongolian Tugrik)

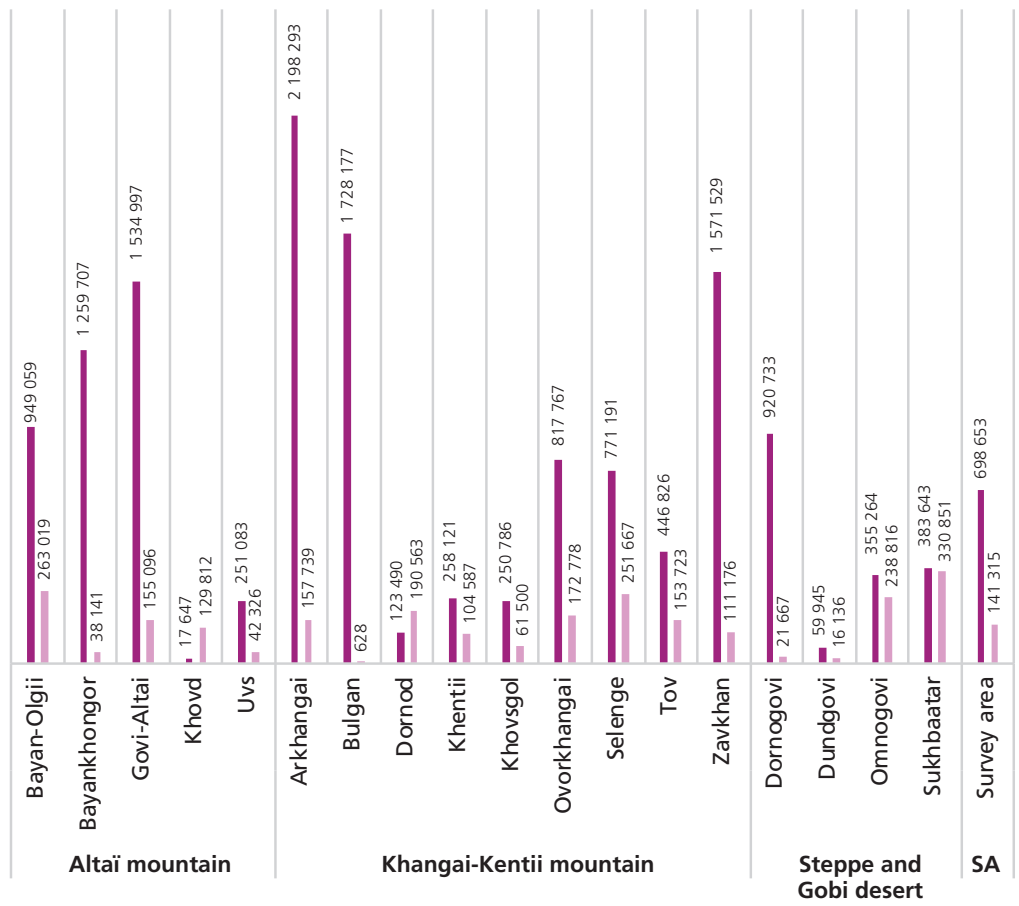

Production costs Other costs

Source: Authors. 

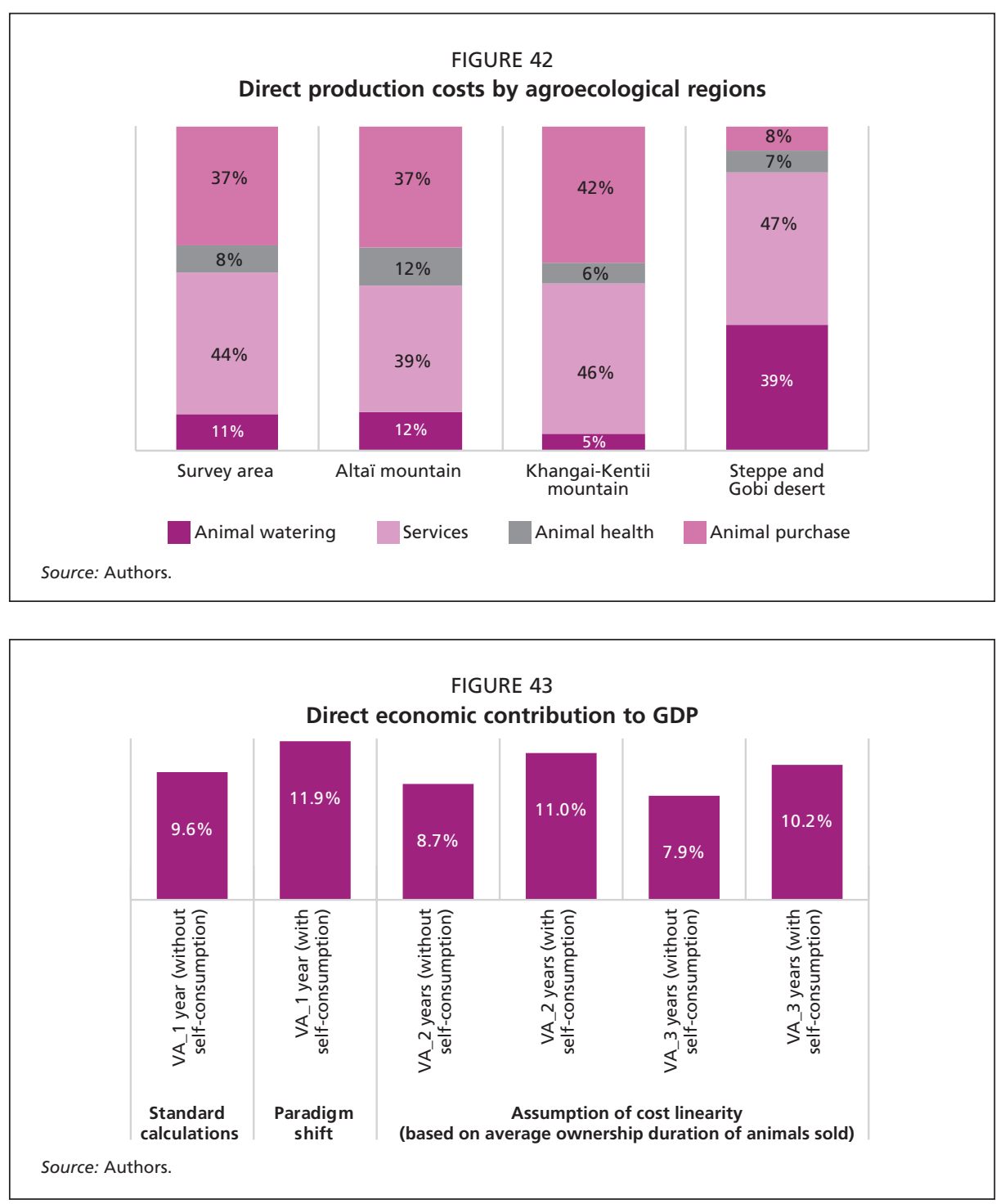

\section{PASTORALISM AND WEALTH CREATION}

In scenario 1, the base-case model, pastoral and agropastoral households in Mongolia contribute $9.6 \%$ of the GDP.

In scenario 2, incorporating self-consumption, which is weak in comparison to Argentina and Chad, the same households contribute $11.9 \%$ of the GDP.

In scenario 3, which incorporates the repetitiveness of production costs during the production process and before the marketing of live animals, the contribution of pastoralists to GDP declines to $8.7 \%$ (without self-consumption) and $11.0 \%$ (with self-consumption), assuming an average holding period of animals sold of two years. This contribution declines even further if the average ownership of animals sold is three years, to reach only $7.9 \%$ (without self-consumption) and $10.2 \%$ (with self-consumption) (Figure 43). 


\section{PASTORALISM AND REVENUE DISTRIBUTION}

In Mongolian pastoral and agropastoral areas, the distribution of all categories of revenue remains strongly unequal.

The revenue from livestock sales presents the worst figures (Gini coefficient of 0.663) and might reflect inequalities related to initial animal endowments.

The strategies and actions developed by pastoralists might also result in reducing revenue inequalities. Indeed, the diversification of activities (crop sales, wage-labor, transfers), slightly contribute to inequality reduction (Gini coefficient of 0.66 ). In addition, the use of production for self-consumption affects the revenue distribution by reducing it (Gini coefficient of 0.63). Moreover, capturing exceptional revenue such as grants and loans is also consistent with inequality reduction (Gini coefficient of 0.61) (Figure 44).

FIGURE 44

Revenue distribution in Mongolian pastoral and agropastoral areas

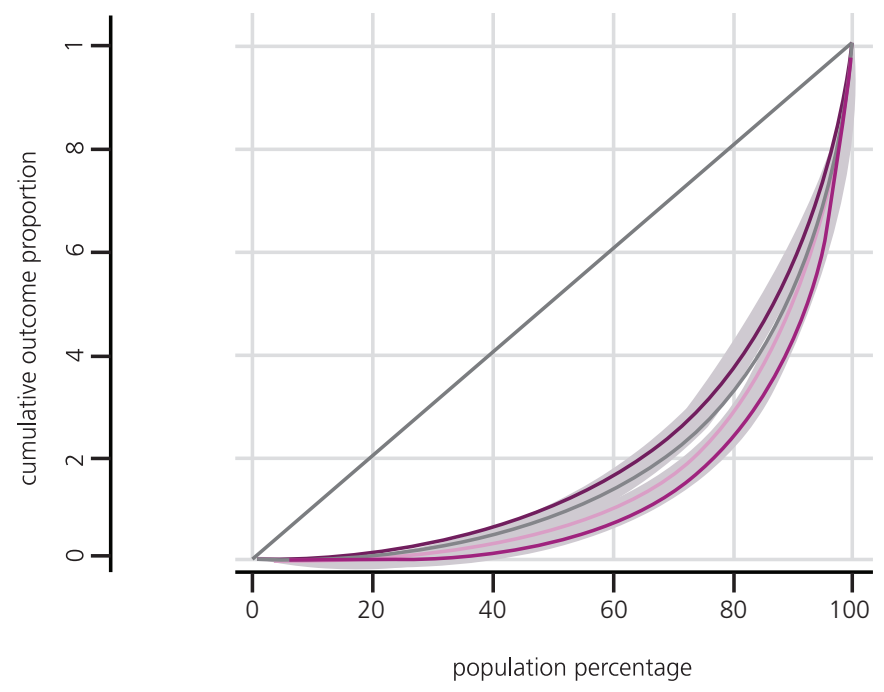

Livestock income (Gini index $=0.663$ )

Monetary income (Gini index $=0.658$ )

Gross income (Gini index $=0.631$ )

Total income (Gini index $=0.614$ )

Source: Authors. 


\section{References}

Alary, V., Corniaux, C., Gautier, D. 2011. Livestock's contribution to poverty alleviation: How to measure it? World Development, 39 (9): 1638-1648

Alary, V., Aboul-Naga, A., El Shafie, M., Abdelkrim, N., Hamdon, H., Metawi, H. 2015. Roles of small ruminants in rural livelihood improvement. Comparative analysis in Egypt. Revue d'Élevage etde Médecine Vétérinaire des Pays Tropicaux 68 (2-3): 79-85.

Ancey, V., Ickowicz, A., Touré, I., Wane, A., Diop, A.T. 2009. La vulnérabilité pastorale au Sahel : portée et limite des systèmes d'alerte basés sur des indicateurs. In: G. Duteurtre \& B. Faye (eds.). L'élevage, richesse des pauvres : Stratégies d'éleveurs et organisations sociales face aux risques dans les pays du Sud. Versailles: Ed. Quae, pp. 117-132.

Banerjee, A., Duflo, E. 2011. Poor Economics, A Radical Rethinking of the Way to Fight Global Poverty. New York: Public Affairs, 2011, 320 pp., ISBN 978-158648798-0.

Barrett, C.B., Bezuneh, M., Abou, A. 2001. Income diversification, poverty traps and policy shocks in Côte d'Ivoire and Kenya. Food Policy, 26: 367-384. doi:10.1016/S03069192(01)00017-3.

Behnke, R., Metaferia, F. 2011. The contribution of livestock to the Ethiopian economy - Part II. IGAD LPI Working Paper 02-11. Addis Ababa.

Behnke, R., Muthami, D. 2011. The contribution of livestock to the Kenyan economy. IGAD LPI Working Paper 03-11. Addis Ababa.

Behnke, R., Osman, H.M. 2011. The contribution of livestock to the Sudanese economy. IGAD LPI Working Paper 01-12, Djibouti.

Blench, R. 2001. You can't go home again. Pastoralism in the new millennium. ODI Report, FAO, $106 \mathrm{pp}$.

Bovin, M. 2000. Pastoralists Manoeuvring in the Drought-Ridden Sahel. In: Manoeuvring in an environment of uncertainty. Structural change and social action in Sub-Saharian Africa. B. Berner \& P. Trulsson (eds.). Ashgate

Callen, T. 2016. Gross Domestic Product: An Economy's All. IMF. [Cited 3 June 2020]. https:// www.elibrary.imf.org/view/IMF073/24615-9781484320921/24615-9781484320921/ch07.xml

Chambers, R. 1989. Editorial introduction: Vulnerability, coping, and policy. IDS Bulletin, 20 (2), 1-7.

Fadiga, M.L. 2013. Valuation of Cattle Attributes in the Malian Humid and Sub-Humid Zones and Implications for a Sustainable Management of Endemic Ruminant Livestock. Environmental Economics, 4 (1): 39-50.

FAO. 2002. État des lieux des ressources génétiques du secteur dans le secteur de l'élevage. Rapport National sur l'État des Ressources Zoo-génétiques, 17 pp.

Grünwaldt, J.M., Castellaro, G., Flores, E.R., Morales-Nieto, C.R., Valdez-Cepeda R.D., Guevera, J.C., Grünwaldt, E.G. 2016. Pastoralism in the drylands of Latin America: Argentina, Chile, Mexico and Peru, Rev Sci Tech., Nov. 35 (2): 543-560. doi:10.20506/ rst.35.2.2526. 
Hatfield, R. \&. Davies, J. (eds.). 2007. Global Review of the Economics of Pastoralism. WISP \& IUCN, Nairobi. https://www.researchgate.net/publication/42766237_Global_Review_of_the_ Economics_of_Pastoralism

ILO. 2003. Rapport 2: Statistiques des revenus et des dépenses des ménages, Dix-septième Conférence internationale des statisticiens du travail. Genève, 24 novembre - 3 décembre 2003, 109 pp.

Inter-Réseaux. 2018. Le pastoralisme a-t-il encore un avenir en Afrique de l'Ouest? Grain de sel n 73-74, juillet 2016 - juin 2017, release date: 5 janvier 2018, 44 pp.

Kerven, C. 1992. Customary commerce: A historical reassessment of pastoral livestock marketing in Africa. London: Overseas Development Institute.

Krätli, S. 2014. If Not Counted Does Not Count? A programmatic reflection on methodology options and gaps in Total Economic Valuation studies of pastoral systems. IIED Issue Paper. IIED, London.

Little, P.D., Smith, K., Cellarius, B.A., Coppock, D.L., Barrett, C. 2001. Avoiding Disaster: Diversification and Risk Management Among East African Herders. Development and Change, 32 (3): 401-433. http://hdl.handle.net/11858/00-001M-0000-0011-9EE2-4

Loison, S.A. 2016. Rural livelihood diversification in Sub-Saharan Africa: A literature review. The Journal of Development Studies, 51: 1125-1138. doi:10.1080/00220388.2015.1046445

Ocaido, M., Muwazi, R.T., Opuda-Asibo, J. 2009. Financial analysis of livestock production systems around Lake Mburo National Park, in South Western Uganda. Livestock Research for Rural Development, 21 (5), http://www.Irrd.org//rrd21/5/ocai21070.htm

Pica-Ciamarra, U. 2005. Livestock policies for poverty alleviation: theory and practical evidence from Africa, Asia and Latin America. Working Paper n. 27. FAO, Pro-Poor Livestock Policy Initiative

Pica-Ciamarra, U., Baker, D., Morgan, N., Zezza, A., Azzarri, C., Ly, C., Nsiima, L., Nouala, S., Okello, P., Serugga, J. 2014. Investing in the livestock sector. Why good numbers matter. A sourcebook for decision makers on how to improve livestock data. World Bank Report n. 85732 - GLB. Washington DC: World Bank.

Republic of Kenya. 2012. Releasing Our Full Potential. Sessional Paper No. 8 of 2012 on National Policy for the Sustainable Development of Northern Kenya and other Arid Lands. Final 11 October 2012, Ministry of State for Development of Northern Kenya and Other Arid Lands, Republic of Kenya, Nairobi.

Swift, J. 1979. West African Pastoral Production Systems. Institute of Development Studies, University of Sussex and Centre for Research on Economic Development, University of Michigan, Ann Arbor.

Thornton, P. K. 2010. Livestock Production: Recent Trends, Future Prospects. Philosophical Transactions of The Royal Society B: Biological Sciences, 365 (1554): 2853-2867. https:// doi:10.1098/rstb.2010.0134

Van Dijk, H. 1997. Risk, agro-pastoral decision making and natural resource management in fulbe society, central Mali, Nomadic Peoples, pp. 108-133

Wane, A. 2005. Marchés de bétail du Ferlo (Sahel sénégalais) et comportements des ménages pastoraux. Paper presented at the symposium of the Société Française d'Economie Rurale SFER, 7-9 novembre 2005, Montpellier, 17 pp.

Wane, A., Touré, I., Ancey, V. 2009a. Pastoralisme et Recours aux marchés - Cas du Sahel sénégalais (Ferlo). Cahiers de l'Agriculture, vol. 1, n. 1, Octobre 2009, pp. 14-20. 
Wane, A., Ancey, V., Touré, I. 2009b. Assets of the Market, Assets of the Rural World - Pastoral Market Income Distribution in the Senegalese Sahel (Ferlo). Journal of Income Distribution, vol. 18, n. 3-4, September-December 2009, pp. 232-248

Wane, A., Ancey, V., Touré, I., Ndiobène Kâ S., Diao Camara, A. 2010. L'économie pastorale face aux incertitudes. Le salariat au Ferlo (Sahel sénégalais) = Pastoral economy facing up to uncertainties. Wage labour in the Ferlo (Senegalese Sahel). Cahiers Agricultures, 19 (5): pp. 359-365. http://dx.doi.org/10.1684/agr.2010.0427

Wane, A., Touré, I., Njiru, N., Mballo, A.D. 2018a. Securing Sahelian pastoralism using a remunerated workforce for livestock for keeping activities: the ambivalence of commodification. Cahiers de l'Agriculture, vol: 170133

Wane, A., Boureima, F., Ndlovu, F., Morton, J. 2018b. Beef Value Chain Analysis in eSwatini. Report for the European Union, DG-DEVCO. Value Chain Analysis for Development Project (VCA4D CTR 2016/375-804), 127 pp.

World Bank. 2017. Mali Livestock Sector Development Support Project (PADEL-M). Project Document, 13 pp. http://documents.worldbank.org/curated/en/381401487363466910/pdf/ ITM00184-P160641-02-17-2017-1487363464632.pdf 

1 Animal breeding: selected articles from the World Animal Review, 1977 (En, Fr, Es, Zh)

2 Eradication of hog cholera and African swine fever, 1976 (En, Fr, Es)

$3 \quad$ Insecticides and application equipment for tsetse control, 1977 (En, Fr)

$4 \quad$ New feed resources, 1977 (En/Fr/Es)

5 Bibliography of the criollo cattle of the Americas, 1977 (En/Es)

$6 \quad$ Mediterranean cattle and sheep in crossbreeding, 1977 (En, Fr)

7 The environmental impact of tsetse control operations, 1977 (En, Fr)

7 Rev.1 The environmental impact of tsetse control operations, 1980 (En, Fr)

8 Declining breeds of Mediterranean sheep, 1978 (En, Fr)

$9 \quad$ Slaughterhouse and slaughterslab design and construction, 1978 (En, Fr, Es)

10 Treating straw for animal feeding, 1978 (En, Fr, Es, Zh)

11 Packaging, storage and distribution of processed milk, 1978 (En)

12 Ruminant nutrition: selected articles from the World Animal Review, 1978 (En, Fr, Es, Zh)

13 Buffalo reproduction and artificial insemination, 1979 (En*)

14 The African trypanosomiases, 1979 (En, Fr)

15 Establishment of dairy training centres, 1979 (En)

16 Open yard housing for young cattle, 1981 (Ar, En, Fr, Es)

17 Prolific tropical sheep, 1980 (En, Fr, Es)

18 Feed from animal wastes: state of knowledge, 1980 (En, Zh)

19 East Coast fever and related tick-borne diseases, 1980 (En)

20/1 Trypanotolerant livestock in West and Central Africa - Vol. 1. General study, 1980 (En, Fr)

20/2 Trypanotolerant livestock in West and Central Africa - Vol. 2. Country studies, 1980 (En, Fr)

20/3 Le bétail trypanotolérant en Afrique occidentale et centrale - Vol. 3. Bilan d'une décennie, 1988 ( $\mathrm{Fr}$ )

21 Guideline for dairy accounting, 1980 (En)

22 Recursos genéticos animales en América Latina, 1981 (Es)

23 Disease control in semen and embryos, 1981 (En, Fr, Es, Zh)

Animal genetic resources - conservation and management, 1981 (En, Zh)

Reproductive efficiency in cattle, 1982 (En, Fr, Es, Zh)

Camels and camel milk, 1982 (En)

Deer farming, 1982 (En)

Feed from animal wastes: feeding manual, 1982 (En, Zh)

Echinococcosis/hydatidosis surveillance, prevention and control: FAO/UNEP/WHO guidelines, 1982 (En)

30 Sheep and goat breeds of India, 1982 (En)

31 Hormones in animal production, 1982 (En)

32 Crop residues and agro-industrial by-products in animal feeding, 1982 (En/Fr)

33 Haemorrhagic septicaemia, 1982 (En, Fr)

34 Breeding plans for ruminant livestock in the tropics, 1982 (En, Fr, Es)

35 Off-tastes in raw and reconstituted milk, 1983 (Ar, En, Fr, Es)

36 Ticks and tick-borne diseases: selected articles from the World Animal Review, 1983 (En, Fr, Es)

37 African animal trypanosomiasis: selected articles from the World Animal Review, 1983 (En, Fr) 
$41 \quad$ Integrating crops and livestock in West Africa, 1983 (En, Fr)

Animal energy in agriculture in Africa and Asia, 1984 (En/Fr, Es)

43 Olive by-products for animal feed, 1985 (Ar, En, Fr, Es)

44/1 Animal genetic resources conservation by management, data banks and training, 1984 (En)

44/2 Animal genetic resources: cryogenic storage of germplasm and molecular engineering, 1984 (En)

45 Maintenance systems for the dairy plant, 1984 (En)

$46 \quad$ Livestock breeds of China, 1984 (En, Fr, Es)

47 Réfrigération du lait à la ferme et organisation des transports, 1985 ( Fr)

48 La fromagerie et les variétés de fromages du bassin méditerranéen, 1985 (Fr)

49 Manual for the slaughter of small ruminants in developing countries, 1985 (En)

50 Better utilization of crop residues and by-products in animal feeding:

research guidelines -1 . State of knowledge, 1985 (En)

50/2 Better utilization of crop residues and by-products in animal feeding: research guidelines -2 . A practical manual for research workers, 1986 (En)

51 Dried salted meats: charque and carne-de-sol, 1985 (En)

52 Small-scale sausage production, 1985 (En)

53 Slaughterhouse cleaning and sanitation, 1985 (En)

54 Small ruminants in the Near East - Vol. I. Selected papers presented for the Expert Consultation on Small Ruminant Research and Development in the Near East (Tunis, 1985), 1987 (En) 1972-1986, 1987 (Ar, En)

56 Sheep and goats in Pakistan, 1985 (En)

57 The Awassi sheep with special reference to the improved dairy type, 1985 (En)

58 Small ruminant production in the developing countries, 1986 (En)

59/1 Animal genetic resources data banks -

1. Computer systems study for regional data banks, 1986 (En)

59/2 Animal genetic resources data banks -

2. Descriptor lists for cattle, buffalo, pigs, sheep and goats, 1986 (En, Fr, Es)

59/3 Animal genetic resources data banks -

3. Descriptor lists for poultry, 1986 (En, Fr, Es)

60 Sheep and goats in Turkey, 1986 (En)

61 The Przewalski horse and restoration to its natural habitat in Mongolia, 1986 (En)

62 Milk and dairy products: production and processing costs, 1988 (En, Fr, Es)

63 Proceedings of the FAO expert consultation on the substitution of imported concentrate feeds in animal production systems in developing countries, 1987 (En, Zh)

64 Poultry management and diseases in the Near East, 1987 (Ar)

65 Animal genetic resources of the USSR, 1989 (En)

66 Animal genetic resources - strategies for improved use and conservation, 1987 (En)

67/1 Trypanotolerant cattle and livestock development in West and Central Africa Vol. I, 1987 (En)

67/2 Trypanotolerant cattle and livestock development in West and Central Africa Vol. II, 1987 (En)

68 Crossbreeding Bos indicus and Bos taurus for milk production in the tropics, 1987 (En)

69 Village milk processing, 1988 (En, Fr, Es)

70 Sheep and goat meat production in the humid tropics of West Africa, 1989 (En/Fr)

71 The development of village-based sheep production in West Africa, 1988 (Ar, En, Fr, Es)

(Published as Training manual for extension workers, M/S5840E)

72 Sugarcane as feed, 1988 (En/Es)

73 Standard design for small-scale modular slaughterhouses, 1988 (En) 
Small ruminants in the Near East - Vol. III. North Africa, 1989 (En)

The eradication of ticks, 1989 (En/Es)

Ex situ cryoconservation of genomes and genes of endangered cattle breeds by means of modern biotechnological methods, 1989 (En)

Training manual for embryo transfer in cattle, 1991 (En)

Milking, milk production hygiene and udder health, 1989 (En)

Manual of simple methods of meat preservation, 1990 (En)

Animal genetic resources - a global programme for sustainable development, 1990 (En)

Veterinary diagnostic bacteriology - a manual of laboratory procedures of selected

diseases of livestock, 1990 (En, Fr)

Reproduction in camels - a review, 1990 (En)

Training manual on artificial insemination in sheep and goats, 1991 (En, Fr)

Training manual for embryo transfer in water buffaloes, 1991 (En)

The technology of traditional milk products in developing countries, 1990 (En)

Feeding dairy cows in the tropics, 1991 (En)

Manual for the production of anthrax and blackleg vaccines, 1991 (En, Fr)

Small ruminant production and the small ruminant genetic resource in tropical Africa, 1991 (En)

Manual for the production of Marek's disease, Gumboro disease and inactivated

Newcastle disease vaccines, 1991 (En, Fr)

Application of biotechnology to nutrition of animals in developing countries, 1991 (En, Fr)

Guidelines for slaughtering, meat cutting and further processing, 1991 (En, Fr)

Manual on meat cold store operation and management, 1991 (En, Es)

Utilization of renewable energy sources and energy-saving technologies by small-scale milk plants and collection centres, 1992 (En)

Proceedings of the FAO expert consultation on the genetic aspects of trypanotolerance, 1992 (En)

Roots, tubers, plantains and bananas in animal feeding, 1992 (En)

Distribution and impact of helminth diseases of livestock in developing countries, 1992 (En) Construction and operation of medium-sized abattoirs in developing countries, 1992 (En)

Small-scale poultry processing, 1992 (Ar, En)

In situ conservation of livestock and poultry, 1992 (En)

Programme for the control of African animal trypanosomiasis and related development, 1992 (En)

Genetic improvement of hair sheep in the tropics, 1992 (En)

Legume trees and other fodder trees as protein sources for livestock, 1992 (En)

Improving sheep reproduction in the Near East, 1992 (Ar)

The management of global animal genetic resources, 1992 (En)

Sustainable livestock production in the mountain agro-ecosystem of Nepal, 1992 (En)

Sustainable animal production from small farm systems in South-East Asia, 1993 (En)

Strategies for sustainable animal agriculture in developing countries, 1993 (En, Fr)

Evaluation of breeds and crosses of domestic animals, 1993 (En)

Bovine spongiform encephalopathy, 1993 (Ar, En)

L'amélioration génétique des bovins en Afrique de l'Ouest, 1993 (Fr)

L'utilización sostenible de hembras F1 en la producción del ganado lechero tropical, 1993 (Es)

Physiologie de la reproduction des bovins trypanotolérants, 1993 (Fr)

The technology of making cheese from camel milk (Camelus dromedarius), 2001 (En, Fr)

Food losses due to non-infectious and production diseases in developing countries, 1993 (En)

Manuel de formation pratique pour la transplantation embryonnaire chez la brebis et la chèvre, 1993 (Fr, Es) 
116 Quality control of veterinary vaccines in developing countries, 1993 (En)

117 L'hygiène dans l'industrie alimentaire, 1993 - Les produits et l'aplication de l'hygiène, 1993 (Fr)

118 Quality control testing of rinderpest cell culture vaccine, 1994 (En)

119 Manual on meat inspection for developing countries, 1994 (En)

120 Manual para la instalación del pequeño matadero modular de la FAO, 1994 (Es)

121 A systematic approach to tsetse and trypanosomiasis control, 1994 (En/Fr)

122 El capibara (Hydrochoerus hydrochaeris) - Estado actual de su producción, 1994 (Es)

123 Edible by-products of slaughter animals, 1995 (En, Es)

124 L'approvisionnement des villes africaines en lait et produits laitiers, 1995 (Fr)

125 Veterinary education, 1995 (En)

126 Tropical animal feeding - A manual for research workers, 1995 (En)

127 World livestock production systems - Current status, issues and trends, 1996 (En)

128 Quality control testing of contagious bovine pleuropneumonia live attenuated vaccine Standard operating procedures, 1996 (En, Fr)

129 The world without rinderpest, 1996 (En)

130 Manual de prácticas de manejo de alpacas y llamas, 1996 (Es)

131 Les perspectives de développement de la filière lait de chèvre dans le bassin méditerranéen, 1996 (Fr)

132 Feeding pigs in the tropics, 1997 (En)

133 Prevention and control of transboundary animal diseases, 1997 (En)

134 Tratamiento y utilización de residuos de origen animal, pesquero y alimenticio en la alimentación animal, 1997 (Es)

135 Roughage utilization in warm climates, 1997 (En, Fr)

136 Proceedings of the first Internet Conference on Salivarian Trypanosomes, 1997 (En)

137 Developing national emergency prevention systems for transboundary animal diseases, 1997 (En)

138 Producción de cuyes (Cavia porcellus), 1997 (Es)

139 Tree foliage in ruminant nutrition, 1997 (En)

140/1 Analisis de sistemas de producción animal - Tomo 1: Las bases conceptuales, 1997 (Es)

140/2 Analisis de sistemas de producción animal - Tomo 2: Las herramientas basicas, 1997 (Es)

141 Biological control of gastro-intestinal nematodes of ruminants using predacious fungi, 1998 (En)

142 Village chicken production systems in rural Africa - Household food security and gender issues, 1998 (En)

143 Agroforestería para la producción animal en América Latina, 1999 (Es)

144 Ostrich production systems, 1999 (En)

145 New technologies in the fight against transboundary animal diseases, 1999 (En)

146 El burro como animal de trabajo - Manual de capacitación, 2000 (Es)

147 Mulberry for animal production, 2001 (En)

148 Los cerdos locales en los sistemas tradicionales de producción, 2001 (Es)

149 Animal production based on crop residues - Chinese experiences, 2001 (En, Zh)

150 Pastoralism in the new millennium, 2001 (En)

151 Livestock keeping in urban areas - A review of traditional technologies based on literature and field experiences, 2001 (En)

152 Mixed crop-livestock farming - A review of traditional technologies based on literature and field experiences, 2001 (En)

153 Improved animal health for poverty reduction and sustainable livelihoods, 2002 (En)

154 Goose production, 2002 (En, Fr)

155 Agroforestería para la producción animal en América Latina - II, 2003 (Es)

156 Guidelines for coordinated human and animal brucellosis surveillance, 2003 (En)

157 Resistencia a los antiparasitarios - Estado actual con énfasis en América Latina, 2003 (Es) 
158 Employment generation through small-scale dairy marketing and processing, 2003 (En)

159 Good practices in planning and management of integrated commercial poultry production in South Asia, 2003 (En)

160 Assessing quality and safety of animal feeds, 2004 (En, Zh)

161 FAO technology review: Newcastle disease, 2004 (En)

162 Uso de antimicrobianos en animales de consumo - Incidencia del desarrollo de resistencias en la salud pública, 2004 (Es)

163 HIV infections and zoonoses, 2004 (En, Fr, Es)

164 Feed supplementation blocks - Urea-molasses multinutrient blocks: simple and effective feed supplement technology for ruminant agriculture, 2007 (En)

165 Biosecurity for Highly Pathogenic Avian Influenza - Issues and options, 2008 (En, Fr, Ar, Vi)

166 International trade in wild birds, and related bird movements, in Latin America and the Caribbean, 2009 (Es $\left.{ }^{\mathrm{e}} \mathrm{En}^{\mathrm{e}}\right)$

167 Livestock keepers - guardians of biodiversity, 2009 (En)

168 Adding value to livestock diversity - Marketing to promote local breeds and improve livelihoods, 2010 (En, Fr, Es)

169 Good practices for biosecurity in the pig sector - Issues and options in developing and transition countries, 2010 (En, Fr, Zh, Ru** Es**)

170 La salud pública veterinaria en situaciones de desastres naturales y provocados, 2010 (Es)

171 Approaches to controlling, preventing and eliminating H5N1 HPAI in endemic countries, 2011 (En, Ar)

172 Crop residue based densified total mixed ration - A user-friendly approach to utilise food crop by-products for ruminant production, 2012 (En)

173 Balanced feeding for improving livestock productivity - Increase in milk production and nutrient use efficiency and decrease in methane emission, 2012 (En)

174 Invisible Guardians - Women manage livestock diversity, 2012 (En)

175 Enhancing animal welfare and farmer income through strategic animal feeding Some case studies, 2013 (En)

176 Lessons from HPAI - A technical stocktaking of coutputs, outcomes, best practices and lessons learned from the fight against highly pathogenic avian influenza in Asia 2005-2011, 2013 (En)

177 Mitigation of greenhouse gas emissions in livestock production - A review of technical options for non- $\mathrm{CO}_{2}$ emissions, 2013 (En, Es ${ }^{\mathrm{e}}$ )

178 Африканская Чума Свиней в Российской Федерации (2007-2012), 2014 (Ru)

179 Probiotics in animal nutrition - Production, impact and regulation, 2016 (En)

180 Control of Contagious Bovine Pleuropneumonia - A policy for coordinated actions, 2018 (En)

181 Exposure of humans or animals to SARS-CoV-2 from wild, livestock,companion and aquatic animals. Qualitative exposure assessment, 2020 (En)

182 The economics of pastoralism in Argentina, Chad and Mongolia - Market participation and multiple livelihood strategies in a shock-prone environment, 2020 (En)

Availability: October 2020
Ar - Arabic
En - English
Es - Spanish
$\mathrm{Fr}$ - French
Pt - Portuguese
Ru - Russian
Vi - Vietnamese
Zh - Chinese

Multil - Multilingual
* Out of print
** In preparation
e E-publication

(En, Fr, Es) $=$ Separate editions in English, French and Spanish $(\mathrm{En} / \mathrm{Fr} / \mathrm{Es})=$ Trilingual edition 
The FAO Animal production and health Papers are available through authorized FAO Sales Agents or directly from Sales and Marketing Group, FAO, Viale delle Terme di Caracalla, 00153 Rome, Italy.

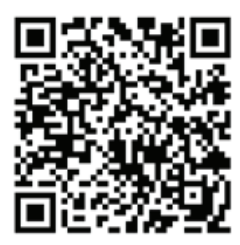

Find more publications at

http://www.fao.org/ag/againfo/resources/en/publications.html 



Pastoralists make the most of resources distributed unevenly over space and time to provide a range of goods and services. Operating in a shock-prone environment, pastoralists deploy endogenous strategies such as mobility, diversification in agriculture or in non-agricultural activities, management of social networks, etc. However, accurate and reliable knowledge about the economics of pastoralism is yet to be understood and absorbed at the local, regional and national levels, based on reliable data. In the absence of such knowledge, governments and private firms neglect investment that would allow those systems to better connect to markets, and are unable to provide appropriate services, infrastructure and tenure security.

With Argentina, Chad and Mongolia as pilot cases, this study by CIRAD, commissioned by FAO, funded by IFAD and facilitated by pastoralist associations (Fundación Gran Chaco, Réseau Billital Maroobé, and the National Federation of Pasture User Groups), aimed to fulfil this knowledge gap through a multifunctional assessment of pastoral production systems and their economic contribution. Importantly, incorporating self-consumption of pastoralist households' productions themselves as an key component of gross revenue shows a significant increase in their contribution to national GDPs. The diversified sources of revenue and the importance of self-consumption also indicate that pastoral systems fulfil a range of functions (income, food security, flexible labor, etc.).

Further, the study promotes close cooperation between pastoralist associations, research institutions and development partners. Such new partnerships allow strengthening the capacity of those pastoralist associations in collecting and managing their own data, as well as using this data in policy dialogue.

Funded by

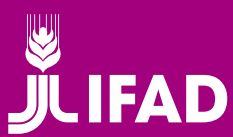

Investing in rural people
ISBN 978-92-5-133377-8 ISSN 0254-6019

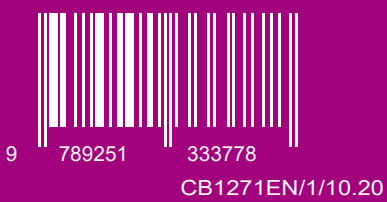

